\title{
Hydrology of the
}

Cavernous Limestones of the Mammoth Cave Area Kentucky

GEOLOGICAL SURVEY WATER-SUPPLY PAPER 1837

Prepared in cooperation with the Commonwealth of Kentucky, the University of Kentucky, Kentucky Geological Survey, Kentucky Department of Commerce, and the National Park Service

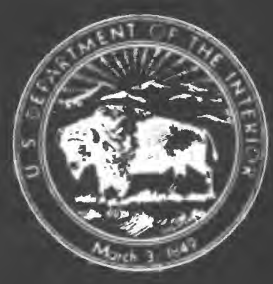




\section{Hydrology of the}

\section{Cavernous Limestones of}

\section{the Mammoth Cave Area}

\section{Kentucky}

By RICHMOND F. BROWN

GEOLOGICAL SURVEY WATER-SUPPLY PAPER 1837

Prepared in cooperation with the Commonwealth of Kentucky, the University of Kentucky, Kentucky Geological Survey, Kentucky Department of Commerce, and the National Park Service

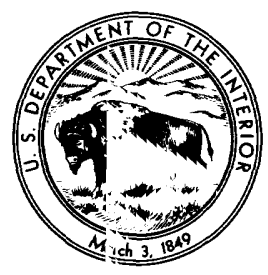




\title{
DEPARTMENT OF THE INTERIOR
}

\author{
MANUEL LUJAN, Jr., Secretary
}

\section{GEOLOGICAL SURVEY}

Dallas L. Peck, Director

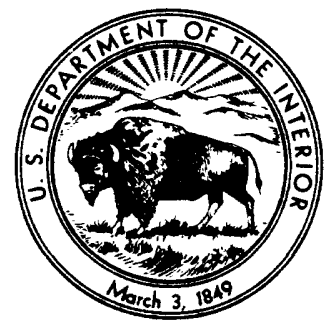

Any use of trade, product, or firm names in this publication is for descrintive purposes only and does not imply endorsement by the U.S. Government

First printing 1966

Second printing 1991

Library of Congress catalog-card No. GS 66-271

For sale by the Books and Open-File Reports Section U.S. Geological Survey, Federal Center, Box 25425, Denver, CO 80225 


\section{CONTENTS}

Abstract

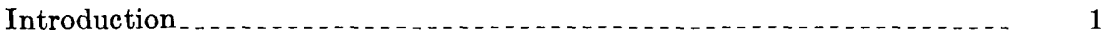

Scope and purpose

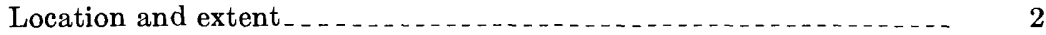

Previous investigations. . .

Well-numbering system

Acknowledgments........ 4

Physiography _............ 4

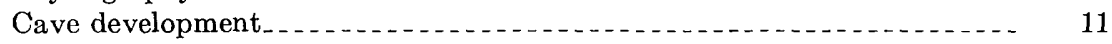

Geologic formations and their water-bearing properties............ 16

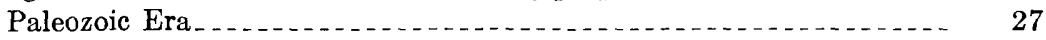

Mississippian System _...

Osage Series . . . .

Fort Payne Formation $\ldots$

Meramec Series.

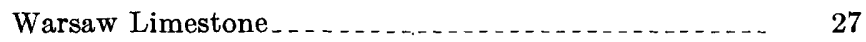

St. Louis Limestone............. 28

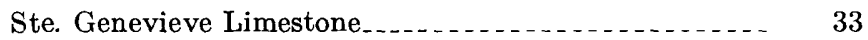

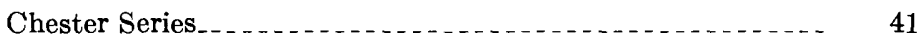

Girkin Formation

Big Clifty Sandstone Member of the Golconda Formation. . .

Haney Limestone Member of the Golconda Formation_ $\quad 43$

Hardinsburg Sandstone......................... 43

Glen Dean Limestone . . . . . . . . . . . . . . . . . 44

Leitchfield Formation . . . . . . . . . . . . . . . . . 44

Pennsylvanian System

Caseyville Formation

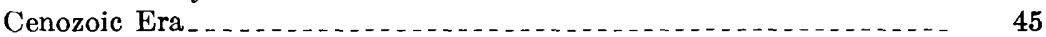

Quaternary System

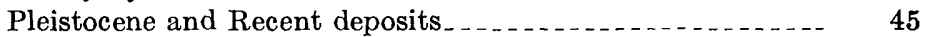

General hydrologic conditions. . . . . . . . . . . . . . . . . . . . . . . . . 46

Fluctuations of water levels and underground-flow relationships _... 49

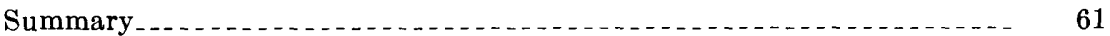

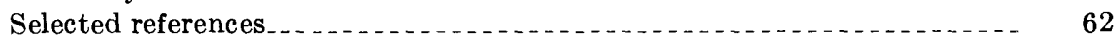

Index . . . 


\section{ILLUSTRATIONS}

FIGURE 1. Sketch showing system of numbering wells and springs _.....

Page

4

2. Map showing major physiographic subdivisions of the Mam-

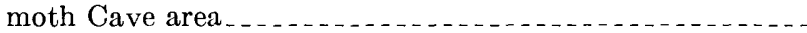

3-8. Photographs of the Mammoth Cave area:

3. Sinkhole depressions and Dripping Springs escarpment near Cave City ..................................

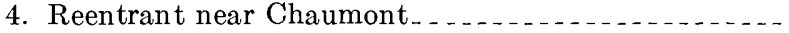

5. Cedar Sink in Cedar Spring Valley . . . . . . . . .

6. Hanging pendants in New Discovery in Mamoth Cave.

7. Main Avenue in Mammoth Cave..............

8. Evaporite dam in New Discovery in Mammoth Cave.

9. Geologic map of the Mammoth Cave area...........

10. Map showing location of wells, springs, and dye tests in the

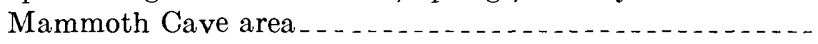

11. Diagrammatic section through the Mammoth Cava plateau.-

12. Hydrographs of wells, and precipitation, 1953-57 . . . . .

13. Hydrograph showing relationship between water level in wells, stage of River Styx Spring and Echo River Spring, stage of Green River, and precipitation, January 10 to February 18 , 1954

14. Hydrograph showing relationship between stage of River Styx Spring, stage of Green River, and precipitstion, April 30 to May 19,1954

15. Hydrograph showing relationship between stage of River Styx Spring and stage of Green River; relationship between chloride concentration and stage in Echo River, River Styx, and Green River; and precipitation, January 18 to February 6, 1959

16. Hydrograph showing effect of precipitation on stage of River Styx, Echo River Springs, and Green River

17. Photograph of Ste. Genevieve Limestone exposed on south side of Cedar Sink

18. Graph showing effect of pumping on water level .........

19. Photograph showing outlet of Echo River. . . .

20. Photograph showing outlet of River Styx

21. Map showing cave passages, major subsurface streams, and gaging stations.

22. Graph showing relation of chloride concentrations in water samples from ground-water to surface-water sources, January $22-29,1959$.

23. Diagram showing relation of discharge and time to concentration of chloride in water from Echo River Spring, 1955-59 _-

24. Diagram showing chloride concentrations in water samples taken from ground-water and surface-water so'rrees, November $3-4,1958$ 


\section{TABLES}

TABLE 1. Generalized section of the geologic formations exposed in the vicinity of Mammoth Cave National Park _._._._.... 18

2. Records of wells in the vicinity of Mammoth Cave National Park

Page

3. Records of springs in the vicinity of Mammoth Cave National

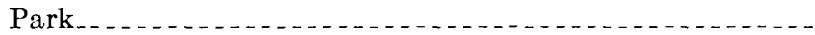

4. Chemical analyses of water from wells, springs, and the Green River in the vicinity of Mammoth Cave National Park . . - 


\title{
HYDROLOGY OF THE GAVERNOUS LIMESTONES OF THE MAMMOTH GAVE AREA, KENTUGKY
}

\author{
By Richmond F. Brown
}

\begin{abstract}
The Mammoth Cave National Park in central Kentucky offers a unique opportunity to study the occurrence of ground water in limestone under naturel conditions. Ground water occurs as perched and semiperched bodies in alternate sandstone, shale, and limestone formations and under water-table conditions at the approximate level of the Green River in thick soluble limestone. Three continuous recorders that operated for 5 years indicate that precipitation on the Mammoth Cave plateau recharges the underlying sandstone rapidly. Ground water from the sandstone discharges horizontally to the edges of the plateau ard vertically to underlying formations. Some of the precipitation recharges underlying formations almost immediately through overland flow to sinkholes and free fall through open shafts to pools at the water table.

Much of the precipitation on the Pennyroyal plain flows overland into sinkholes and then through solution openings to the Green River. Water from the Green River flows into limestone solution channels under Mammoth Cave plateau at some stages, and this water discharges again to the Green River dowrstream. The presence of salt water, high in chloride in the Green River, makes it possible to trace the movement of the river water through the underground streams. Graphs show relationships of chloride concentration, stage of the Green River. time, precipitation, ground-water levels, and stratigraphy.
\end{abstract}

\section{INTRODUCTION}

\section{SCOPE AND PURPOSE}

In order that the use and conservation of the water resources of the Commonwealth of Kentucky may be planned most effectively, the Commonwealth, through the Kentucky Department of Commerce (formerly the Department of Economic Development) and the Kentucky Geological Survey, has entered into cooperative agreements with the U.S. Geological Survey providing for studies of the water resources. This report, prepared as a part of the cooperative g"oundwater investigations, is a progress report of a basic research project which will yield information on the principles of the occurren re and movement of ground water in cavernous limestone.

A preliminary investigation of the occurrence and movement of ground water in the vicinity of Mammoth Cave National Park was 
made during the summer of 1953 for the National Park Sarvice. During the remainder of 1953 and continuing to the present (September 1959), data were obtained from recording gages installed on selected wells and from gage-height readings of water bodies in the cave, streams, and springs in cooperation with the Kentucky $\Gamma$ spartment of Commerce, the Kentucky Geological Survey, and the National Park Service.

Beginning in 1958, large quantities of oil were prodvsed in Green County, upstream from Mammoth Cave National Park. Considerable brine, high in chloride, was produced with the oil, and much of this brine discharged into the Green River. For the first time since investigations began in the Mammoth Cave area, the water in the Green River could be easily distinguished by its chemical character from the waters of the underground streams in the park area. As a part of an investigation of the geochemistry of natural waters of the upper Green River basin, samples were collected in 1958 and $\$ 959$ from the underground rivers and springs and from streams in the area. At the same time, additional data were obtained from stream gages and water-level recording gages. The combination of two distinctive chemical types of water and a limestone aquifer that hes been extensively dissolved by ground water offers a unique opportunity for a better understanding of the occurrence of ground water in limestone. This paper presents the results of the investigation to September 1959 .

The investigation included that part of Mammoth Cave National Park lying south of the Green River and the areas adjoining the park to the south and east. It included parts of Barren, Edmonson, and Hart Counties (fig. 2).

\section{LOCATION AND EXTENT}

The area investigated is about 100 miles southwest of Louisville, Ky. It includes about 80 square miles and is divided into two parts by the Dripping Springs escarpment (fig. 2). On the south and southeast side of this escarpment lies the Pennyroyal plain or sinkhole plain. North and northwest of the escarpment is the Mammoth Cave plateau, lying about 250 feet above the Pennyroyal plain. The incorporated towns in the area, Park City, Cave City, and Horse Cave, are all on the Pennyroyal plain.

\section{PREVIOUS INVESTIGATIONS}

Mammoth Cave and the national park area have been described in numerous publications over a period of years. The most definitive work in the area is by James Marvin Weller (1927). T'9 physiography of the region is described in a report by A. K. Lobeck (1928). An 
excellent popularized discussion of the geology and cave features has been published by the Kentucky Geological Survey (Livesay, 1953). None of these reports describe ground-water conditions in c'stail, though Lobeck noted that water availability was a major problem in the area. Ground-water movement in the area and the general processes of solution in limestone are discussed in papers by Davis (1930), Bretz (1942), Dicken (1935), and Pohl (1955). Each of these p?pers has served as an important reference for the present study.

\section{WELL-NUMBERING SYSTEM}

The wells and springs tabulated in this report are numbered to conform to the Kentucky plane-coordinate numbering system used by the Ground Water Branch throughout Kentucky.

Under this system, the State is divided into two zones, a north and a south zone, each consisting of two sets of parallel straight lines that intersect at right angles to form a grid.

The gridlines in each zone are 10,000 feet apart and are numbered in feet from arbitrarily assigned datum lines. The numbers assigned to the east-west gridlines increase to the north, and are determin ad by the distance that these lines are from an east-west datum line lying to the south of each zone. The numbers assigned to the north-south gridlines increase to the east, and are determined by the distance that these lines are from a north-south datum line lying to the west of each zone.

Each well or spring is designated by a letter followed by a number. The letter assigned is " $\mathrm{N}$ " if the well or spring is in the north zona and "S" if it is in the south zone.

The number following each letter is in two parts. The first part of the number is obtained by adding the distance in feet the well or suring is east of the nearest north-south gridline to the number of that line and dividing the sum by 1,000 to shorten it. The second part of the number is obtained by adding the distance in feet the well or suring is north of the nearest east-west gridline to the number of that line and dividing the sum by 1,000 .

In the Mammoth Cave area in the south zone, for example, a soring (River Styx outlet) that is 5,500 feet east of the 1,890,000-foot gridline and 1,000 feet north of the 310,000-foot gridline is numbered S1,895.5-311.0 (fig. 1). Because the distance of the well or spring from the gridline is usually computed to the nearest hundred feet, thore is only one decimal place in the number. However, the number may be carried out to 2 or 3 decimal places if it is necessary to locate the well or spring more accurately. By this method each well or spring is assigned a number which is not only unique to that well or soring but precisely expresses its location on the map. 


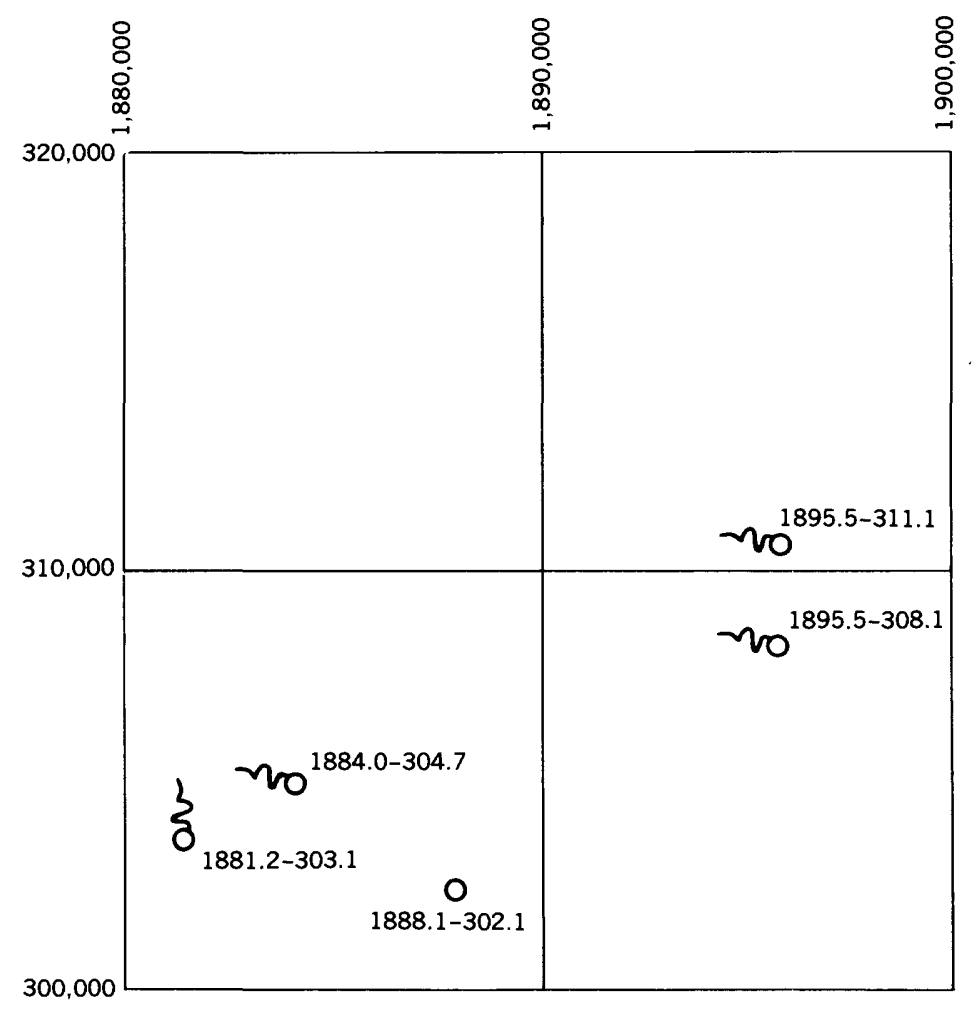

FTGURE 1.-System of numbering wells and springs.

\section{ACKNOWLEDGMENTS}

Many residents in the area gave information about their wells and permitted measurements to be made in their wells. Appreciation is expressed to personnel of the National Park Service for their cooperation and to W. Ray Scott, National Park Concessions, Inc., for the use of photographs of the area. The Louisville Gas \& Electric Co. furnished several maps and reports from their files whicl were valuable in some areas. Dr. E. R. Pohl, Director, Mammoth Ony Cave, gave helpful advice and information on the geology and phyciography of the region.

\section{PHYSIOGRAPHY}

The topography of the area is controlled by the geologic succession, the structure, and the present position of major drainage channels. The major physiographic features in the Mammoth Cave area are shown in figure 2. From oldest to youngest, the ganeral geologic sequence is rocks of the Osage, Meramec, and Chester. Series of the Mississippian System and Caseyville Formation of the Pennsylvanian 


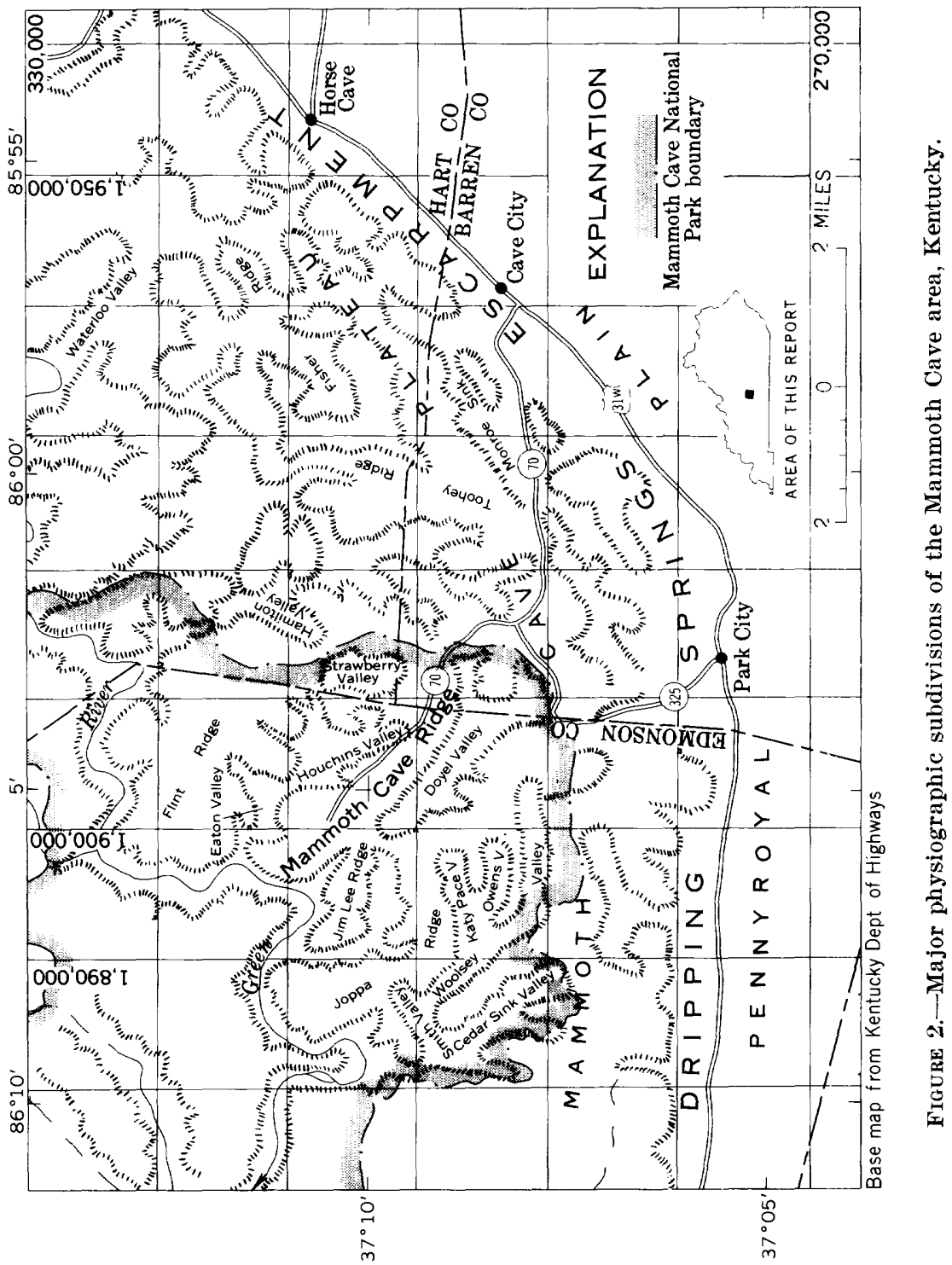


System. The rocks of the Osage and the lower part of the Meramec Series are relatively insoluble in ground water. The rocks of the upper part of the Meramec are very soluble in ground water, and it is in this part of the series that most of the solutional features in the area are developed. Lying above these soluble limestone rocks is the Girkin Formation in the lower part of the Chester Series, which apparently is as soluble as rocks in the upper part of the Meramec; but above this, the rocks are relatively insoluble and are eroded principally by processes of normal erosion. These rocks above the Girkin consist of alternating beds of sandstone and limestone and some interbedded shale; they are capped with a sand and gravel conglomerate of PennsyJvanian age. All these beds dip northwestward about 25 feet per mile.

Within the Mammoth Cave National Park south of the Green River, the Big Clifty Sandstone Member of the Golconda Formetion, lowest formation of the middle part of the Chester Series, caps most of the ridges. Extensive solution has taken place beneath this cap, generally to approximately the level of the Green River. West of the park, the Big Clifty Sandstone Member is much lower relative to the Green River, and there is, therefore, not a thick section of soluble rocks in which an extensive solution drainage pattern can be formed. Accordingly, in this area the drainage is generally normal surface drainagedendritic and continuous. East of the park area, the rocks of Osage age are exposed, and, inasmuch as they are relatively insoluble, only slight solution action has taken place in this area. Just below the escarpment to the south and east, drainage is through solution channels; but 2 miles or more southeast of the escarpment the relatively insoluble rocks of the Osage are exposed, and here the drainage is superposed.

The sinkhole depressions (funnel-shaped openings through which surface water drains into underground solution channels) in the Pennyroyal plain range in depth from about 1 foot to about 100 feet. In a plan view they range in size from about 1 foot to about 2,000 feet in their longer dimension. In general, sinkholes less then 20 feet in diameter have steep sides, sometimes nearly vertical; the larger sinkholes have gently sloping sides. Most are approximately round in plan view, but solution action sometimes causes adjacent sinkholes to coalesce and ultimately to form a series of sinkholes with their long dimensions in the direction of the major underground drainage (fig. 3). The sinkholes are present over almost the entire area of the plain that is underlain by limestone of the upper part of the Meramec Series. They are evenly spaced and have no obvious areal pattern. Pohl $(1955$, p. 13) ascribes their origin to a process of vertical sl aft development now taking place at valley heads on the Mammoth Cave plateau.

In the southern part of the area, which is underlain by the Warsaw Limestone of early Meramec age, there are relatively few sinkholes. 


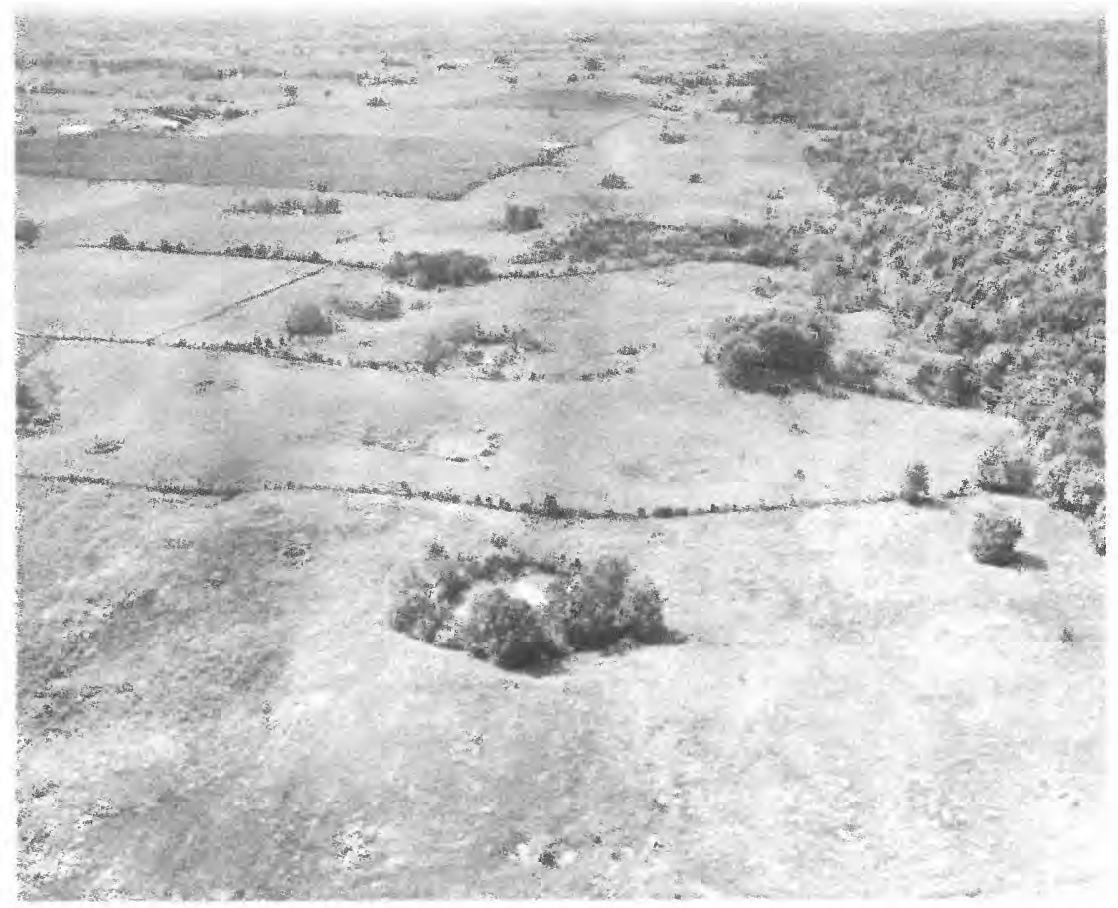

Frgure 3.- Sinkhole depressions and Dripping Springs escarpment near Cave City. Dripping Springs escarpment, capped by Big Clifty Sandstone Member of Golconda Formation, is the wooded area to the right; the Pennyroyal plain lies to the left. The sinkholes are developed in Meramec rocks. The series of sinkholes that trend from central left diagonally up to the escarpment (marked in part by trees) overlie a major subsurface channel. The bottom of the sinkhole in the foreground is plugged, and the water is perched above the local water table. Photograph by W. Ray Scott.

Several streams in this area flow north and northwest toward the escarpment. Some are perennial streams, but all terminate in one or more sinkholes. Even after torrential rains during late winter, these streams cannot maintain a surface flow on the St. Louis Limestone. Both surface erosion and solution action are lowering the surface and extending the Warsaw-St. Louis boundary progressively northwestward. As a result, the area drained by surface streams is increasing, and the area of sinkhole drainage is decreasing. Seemingly, the present stream valleys are remnants of former subsurface channels. They are alined to joint systems and do not show evidence of dendritic development.

The deepest sinkholes are near the edge of the Dripping Springs escarpment. These include Monroe Sink, east of Kentucky State Route 70, and Mill Hole (S-1,893.0-283.3), about 4 miles west of Park City. Monroe Sink is about half a mile in length and 200 feet deep. 


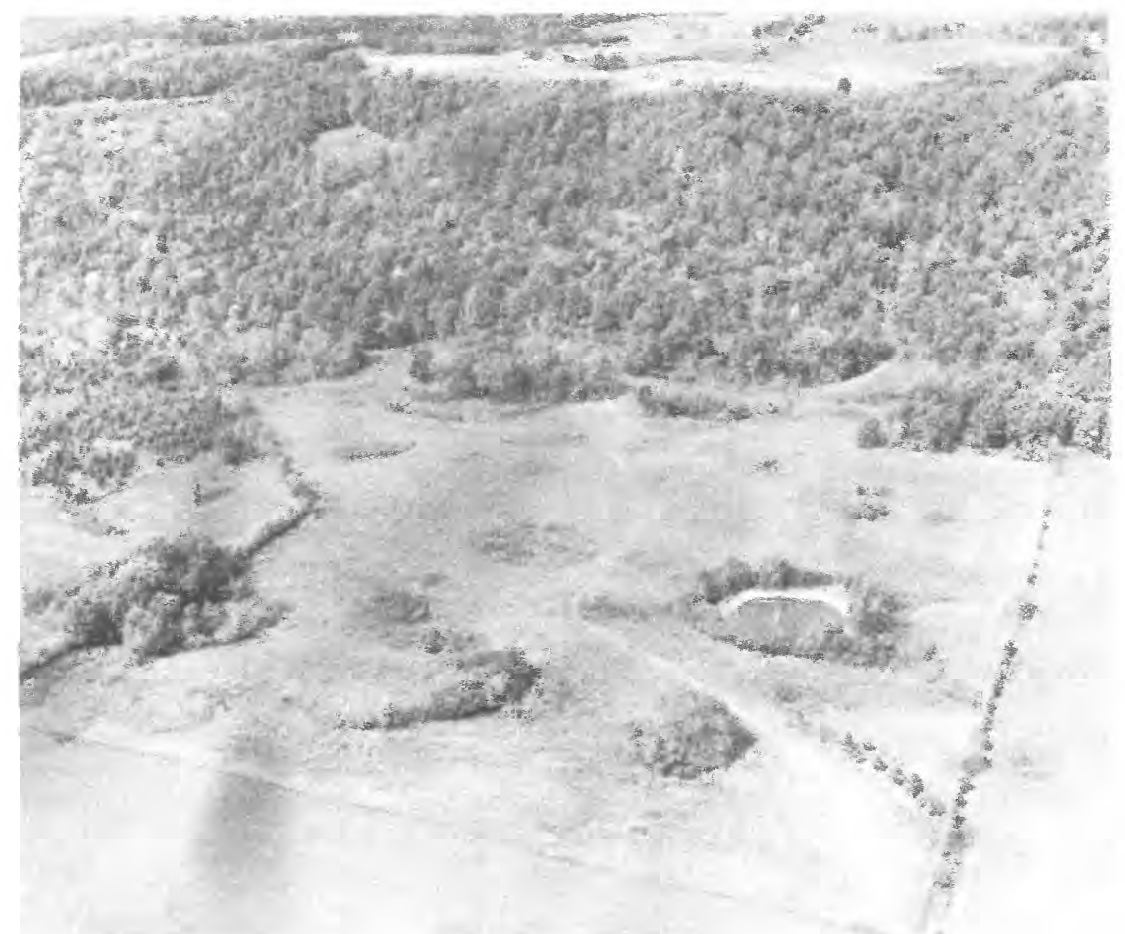

Figure 4.- Reentrant near Chaumont. Mammoth Cave Ridge, capped by the Big Clifty Sandstone Member of the Golconda Formation, shows in background above the Dripping Springs escarpment. Minor sinkholes are developed in the base of the reentrant. Water that drains out of these sinkholes flows northward through subsurface channels under the escarpment. Photograph by W. Ray Scott.

It is the largest single sinkhole in the region and is typical of several others along the edge of the escarpment. Mill Hole is similar in many ways; however, Mill Hole is deeper and the floor intersects a throughflowing subsurface stream. Several of the sinkholes along the edge of the escarpment are elongated, have coalesced with other sinks, and form large reentrants into the escarpment. The orientation of these reentrants is controlled by two factors. Some are parallel to joint systems through part of their length, but the agreement with fractures or structure is not everywhere apparent. Some reentrants, particularly the one near the Chaumont well (S-1,907.4-289.6), are alined with the valleys that are cut into Mammoth Cave platean (fig. 4).

From the Dripping Springs escarpment to the Green River, the upland surface is capped with the Big (lifty Sandstone Member of the Golconda Formation. The dip slope of the surface is toward the northwest at about 25 feet per mile. Iarge northwest-trending closed valleys dissect this upland surface. These are subsequent valleys 
superposed on cavernous limestone. Each valley consists of numerous sinkholes coalesced to form one large depression. The altitude of the base of each of these valleys is close to that of the Green River, but only Cedar Sink (S-1,882.2-297.1) in Cedar Valley is deep enough to intersect this level. There is no surface flow in any of the valleys, except during periods of extreme precipitation when some water may overflow from one sinkhole into adjacent ones. The heads of each of the valleys tributary to the master valleys are abruptly terminated. Where each of these tributary valleys terminates against the upland, a sinkhole is developed. These sinkholes have large vertical shafts under them, and it is largely through lateral expansion and coalescing of the verticle shafts that the upland is now being dissected (Pohl, $1955)$.

The gross drainage pattern of the valleys is dendritic, and is a remnant of subsequent drainage developed on the dip-slope surface of the Big Clifty Sandstone Member during Tertiary time (Weller, 1927, p. 50). In the large valleys, subsurface solution channels now carry all the drainage during periods of normal flow. Ephemeral dendritic tributary streams still persist on the surface in some areas adjacent to the more extensive upland divides; however, continued solution action will decrease the areal extent of the ridges and increase the area that is drained exclusively through subsurface solution channels. Surface drainage will not predominate in the area again until the floor of the valleys has a normal gradient to the local base level, the Green River.

Three ridges are dominant on the upland (fig. 2). Flint Ridge, on the northeastern edge of the park, is underlain by many large caves including Crystal, Colossal, and Great Onyx Caves. Small sinkholes are at the heads of most of the valleys that dissect the edges of the ridge, but none is on the surface of the upland. Flint Ridge, is about 2 miles wide and more than "s miles long, and is bounded on the east by a large unnamed valley that lies about 300 feet below the upland of Flint Ridge and on the west by Eaton and Houchens Valleys and an isolated depression, Strawberry Valley. The bottoms of these valleys are about 200 feet below the upland. Southwest of these valleys is Mammoth Cave Ridge, under which are the famed caverns of Mammoth Cave. Mammoth Cave Ridge trends northwestward and is about half a mile wide and more than 3 miles long. Jim Lee Ridge is a thumblike projection west from Mammoth Cave Ridge. The New Discovery, a large cave found in 1938 by traversing several small passageways from one of the lower levels of Mammoth Cave, underlies this ridge. $\Lambda$ though the perimeter of these ridges is bounded by large sinkholes, there are almost no sinkholes in the upland surface. These two ridges are bounded on the southwest by Doyel Valley. 
The bottom of Doyel Valley is in places nearly 300 feet below the upland, but nowhere does it extend deep enough to intersect the level of the Green River or the water table that is graded to that level.

West and southwest of Doyel Valley is Joppa Ridge, which also trends northwest ward. It is as much as 2 miles wide and about 3 miles long. Sinkholes are rare on the crest of the ridge, although they are abundant on the perimeter. No large caverns have been discovered under Joppa Ridge.

On the southwest side of Joppa Ridge is another large valley, branches of which are called Cedar Spring, Smith, Woolsey, Owens, and Katy Pace Valleys. The lowest part of this valley complex, the bottom of Cedar Sink in Cedar Spring Valley, is at an altitude of about 420 feet, and about 340 feet below Joppa Ridge. Cedar Spring Valley has a well-defined connection with the Pennyroyal plain, and the subsurface stream that flows beneath the floor of the valley is probably the one that is visible not only in the bottom of Cedar Sink (fig. 5), but

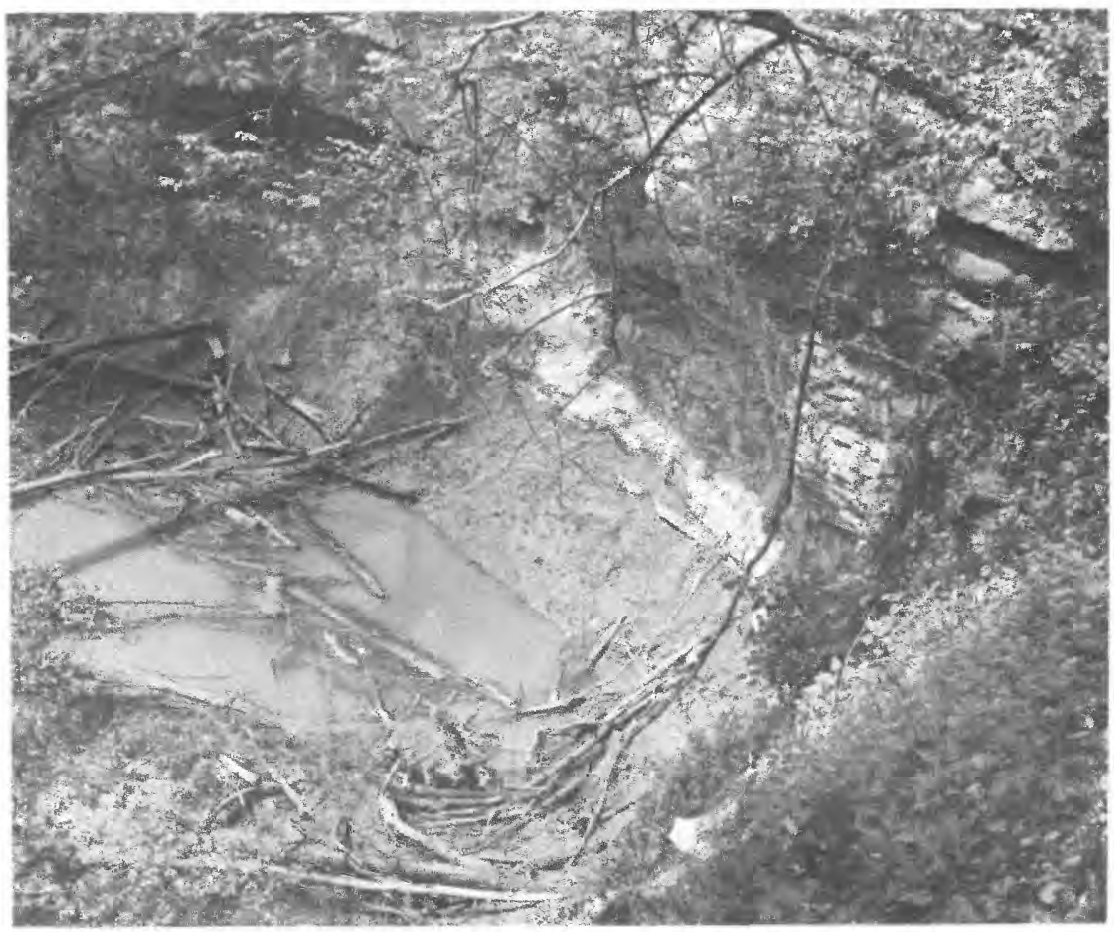

Figure 5.-Cedar Sink in Cedar Spring Valley intercepts the regional water table between the Pennyroyal plain and the Green River. The water level in Cedar Sink is slightly higher than the Green River at the Turnhole. The inlet to the sink is a partly collapsed cavern to the left of the photograph and is larger than the outlet. High flows from the Pennyroyal plain to the river form a large temporary lake in the sinkhole, and a whirlpool develops at this site. The lake sometimes overflows through the left foreground to a second sinkhole. Photograph by W. Ray Scott. 
also in the bottom of Mill Hole, a sinkhole near the edge of the escarpment. A large spring that discharges from a sinkhole adjacent to the Green River, known as the Turnhole, is probably the discharge point for some, if not all, of the water that flows under the floor of Cedar Spring Valley.

West of Cedar Spring Valley, the topography is characterized by short dendritic perennial streams which flow generally northward into the Green River. South of the headwaters of these streams, drainage is into Beaver Dam Creek. Although some of the tributaries to Beaver Dam Creek drain into sinkholes, the area as a whole is not. karst topography. The few sinkholes on the surface are shallow and relatively small. The area is underlain by relatively insoluble beds of alternating sandstone and limestone of middle Chester age. The escarpment west of the Mammoth Cave area is distinctively different. Instead of an irregular escarpment indented with sinkholes and extensive valley sinks, it is regular in outline and everywhere very steep. Streams as much as a mile in length that are tributary to Beaver Dam Creek flow northward from the top of the escarpment down the dip slope of formations in the middle part of the Chester. Below the escarpment in this area the karst surface on the Pennyroyal plain is particularly well developed in formations of early Chester and late Meramec ages.

Northwest of the Green River the topography is markedly different. Solution features are principally a few caves along the bluffs on the north side of the river and some just north of the river opposite Joppa Ridge. None of the caves is more than a few hundred feet in length (E. R. Pohl, written commun., 1938). The formations north of the river consist of layers of sandstone and limestone of Chester age capped by a conglomerate of the Pennsylvanian System. The area is drained by short ephemeral streams with steep gradients. The drainage is typically dendritic and is little affected by solution action.

\section{CAVE DEVELOPMENT}

Mammoth Cave National Park is world famed for the size and length of its passageways. Within the boundaries of the national park are many miles of passageways which display every type of cave formation. Much has been learned in recent years of the processes that create such a labyrinth of underground passages, but much research is still needed to explain details of how the caves were formed.

The major caves underlie ridges. Mammoth Cave underlies Mammoth Cave Ridge; Crystal Cave, Colossal Cave, and Great Onyx Cave underlie Flint Ridge; and New Discovery underlies Jim Lee Ridge. Caves may have formerly existed in what are now open valleys between the ridges, but the valleys have been so eroded that no evidence 
of caves remains above the water table. Below the water table there are reported to be small solution openings in some valleys. $\Lambda$ test hole drilled in Eaton Valley to locate new water supplies for the mational park headquarters area failed to penetrate any significant openings to a depth of 322 feet. Explorations in westward extensions of (rystal Cave are reported to have located some caverns that are under Eaton Valley, but their extent is not known.

The southern edge of the I)ripping Springs escarpment is the southern edge of the cave area. The Dripping Springs escarpment is (alpped with the Big (Clifty Sandstone Member of the Golconda Formation which, in turn, is underlain by thick deposits of limestone. The caves are formed in the limest one, and the Big Clifty protects the escarpment from complete erosion. Where the sandstone cap has been removed by erosion, or where it is close to the base level of the Green River, as in the northwestern part of the park, there is no cave development.

At one time the cap of the Big (Clifty Sandstone Member extended several miles south of the present escarpment. Retreat of the escarpment from its original position toward the Green River was caused by solution of the underlying limestone. The present position of the escarpment coincides in this area with a northward-facing monoclinal structure in the underlying Chatanooga Shale of Devonian age. This structure probably controlled the movement of subsurface water and the extent of erosion by solution. Solution took place most rapidly along the escarpment edge. Pohl (1955) ascribes the retreat to the development of vertical shafts formed by vertical enlargement of cross joints by downward-seeping surface water. Development of these shafts can be observed in the dome pits in Mammoth Cave. Remnants of former vertical shafts can be seen on the Pennyroyal plain below the Dripping Springs escarpment where the numerous sinkholes presumably mark the sites of former shafts.

The major horizontal passageways in the park are developed in the Ste. Genevieve Limestone. Higher caves on the plateau are developed in part in the Girkin Formation; the few caves on the Pennyroyal plain are developed in the St. Louis Limestone. The vertical shafts or dome pits extend from the lower Chester sandstone down into the Meramec.

Ill the cavernous area was developed in limestone formations by the dissolving action of ground water. Limestone is slightly soluble in pure water, but it is about 30 times more soluble in water containing a small amount of carbon dioxide. Rainwater contains small amounts of carbon dioxide and picks up small amounts of humic acid from soils as it moves into the ground. To be effective in dissolving limestone, water must be in motion; water which has become saturated with 
calcium carbonate must leave the area, and unsaturated water must be constantly available for replacement.

Water exists in the ground in two environments. These are called vadose and phreatic. Vadose water is in the upper zone, or zone of acration, where pore space in rocks is normally filled with air. Vadose water flows through fractures in the limestone much as a stream flows down a steep hill. Phreatic water is in the lower zone where all pore spare is saturated. Vadose water moves down to the phreatic zone under the influence of gravity. In the phreat ic zone, water moves from areas of high head (sontheast of the escarpment) to areas of low head (Green River). Circulation of phreatic water takes place from the water table to below local drainage.

The major passageways of Mammoth ('ave were formed initially in a phreatic environment. Solution enlargement took place first along the joints and bedding planes. Subsequently, these enlarged and joined to form major roons and passageways. 'The orientation of the caverns coincides ronghly with the joints or fracture patterns in the rocks in the area, trending northwest and northeast. Solution has been so extensive in many areas that the initial orientation of a cavern passageway or room is difficult to determine, but overall, the pattern is easily recognized. Caverns in adjoining Crystal Cave are oriented alongr the same joint patterns ats are segments of the meanders of the Green River. Secondary modifiration of the passageways took place in a vidose environment.

The floors of most of the passageways are developed on bedding plines. The numerous levels of cavern development are comnerted by short steep caverns developed where solublity of a bed was greater than average. Probably the levels in Mammoth Cave, discussed by previous anthors, have been overemphasized. In a phreat ic environment, solut ion takes place at all levels at the same time. I substantial difference in head between the former recharge area south of the area shown in figure 2 and the discharge area along the Green River would result in circulation to depths as great as solution openings are known to exist, some to feet below the present level of the Green River. Some authors, following swimnerton (1932), believe that circulation was as much more rapid near the surface of the water table. This is certainly the situation at present where flow takes place through River Styx and Erho River. It would not be as true if the water table were assumed to lie somewhere in the Chester Series during the period of cave formation.

The problem of reconstructing the history of cave formation is complicated by the complex glacial history of the region. The deep valley of the Green River, about 40 feet below the level of the present valley floor, was carved cluring Yarmouth time (Walker, 1957, p. 6). Dur- 
ing Illinoian and Wisconsin Glaciations the Green River valley was alternately aggraded and eroded, and fill in the valley was probably many tens of feet. It is probable that most of the caverns were formed during pre-Pleistocene time, but they were greatly modified and enlarged during the Pleistocene. A sample of guano from Chief City on the Historic Entrance has been dated at more than 38,000 B.P. (before present) (W. E. Davies, written commun., 1960), indicating no major changes in this part of the cave since that time.

A two-cycle origin of the caves (a first cycle of phreatic and later vadose conditions) is indicated by numerous features. Most prominent among those that indicate a phreatic cycle are the spectacular pendants shown in figure 6 . These were formed in the zone of saturation by water that completely filled the cavern and moved very slowly from areas of high head to areas of low head. The beautifully etched patterns are the result of differences in solubility of the limestone. Figure 7 shows similar etching near the ceiling and also a flat relatively insoluble bed forming the cave ceiling which prevented further vertical enlargement of the passageway.

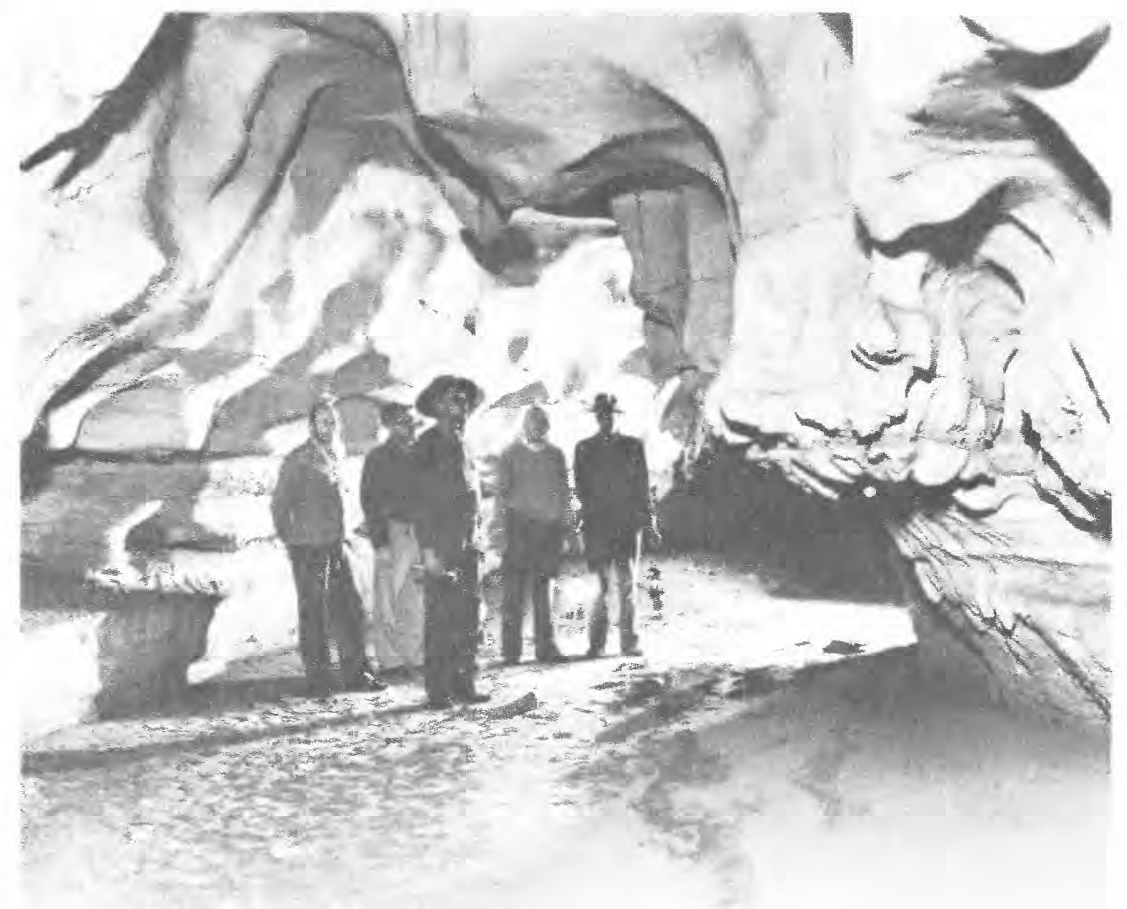

Figure 6.-Hanging pendants in New Discovery in Mammoth Cave show the uniform solution action of slow-noving waters under phreatic conditions. The undisturbed floor is underlain by several feet of silt and clay deposited in standing water. Photograph by W. Ray Scott. 


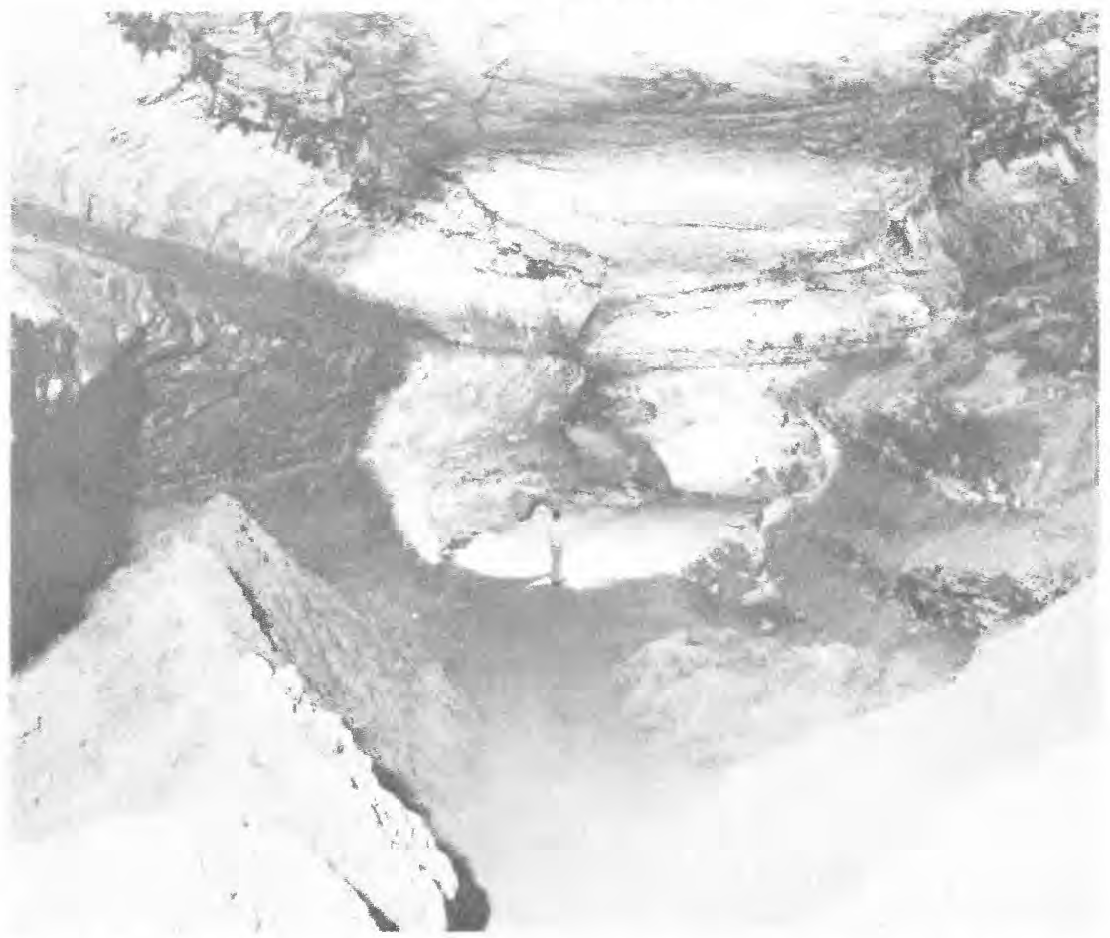

Figure 7.-Main Avenue in Mammoth Cave. Hanging pendants are along the upper right and left borders. Solution action was ineffectual on bed that forms the flat ceiling. Piles of silt are the result of mining the cave for saltpeter. Photograph by W. Ray Scott.

Other features in the caves that Bretz (1956) lists as evidence of phreatic origin include joint-determined wall and ceiling cavities, and bedding-plane and joint-plane anastomosing. The latter features are systems of minor curvilinear tubelike solution cavities lying along interconnecting bedding and joint planes.

The Echo River and River Styx are vadose streams which are imposed on the phreatic caverns and show a second set of features that are characteristic of normal erosion. These include incised meanders and horizontal grooves in cave walls. Some tributaries to these major streams also show vadose features. Incised meanders are particularly well displayed in Robertson Avenue near Fairy Spring.

Secondary deposition under the vadose conditions in air-filled caves has resulted in the formation of many types of evaporite deposits including the familiar flowstone, stalactites, and stalagmites. Less commonly seen features include evaporite dams, one of which is shown in figure 8 . This dam, almost 2 feet high, was formed by deposition of evaporites at the edge of a pond. Rippling of the surface from dripping water caused intermittent overflow of the dam. Evaporation of this overflow built the dam higher. 


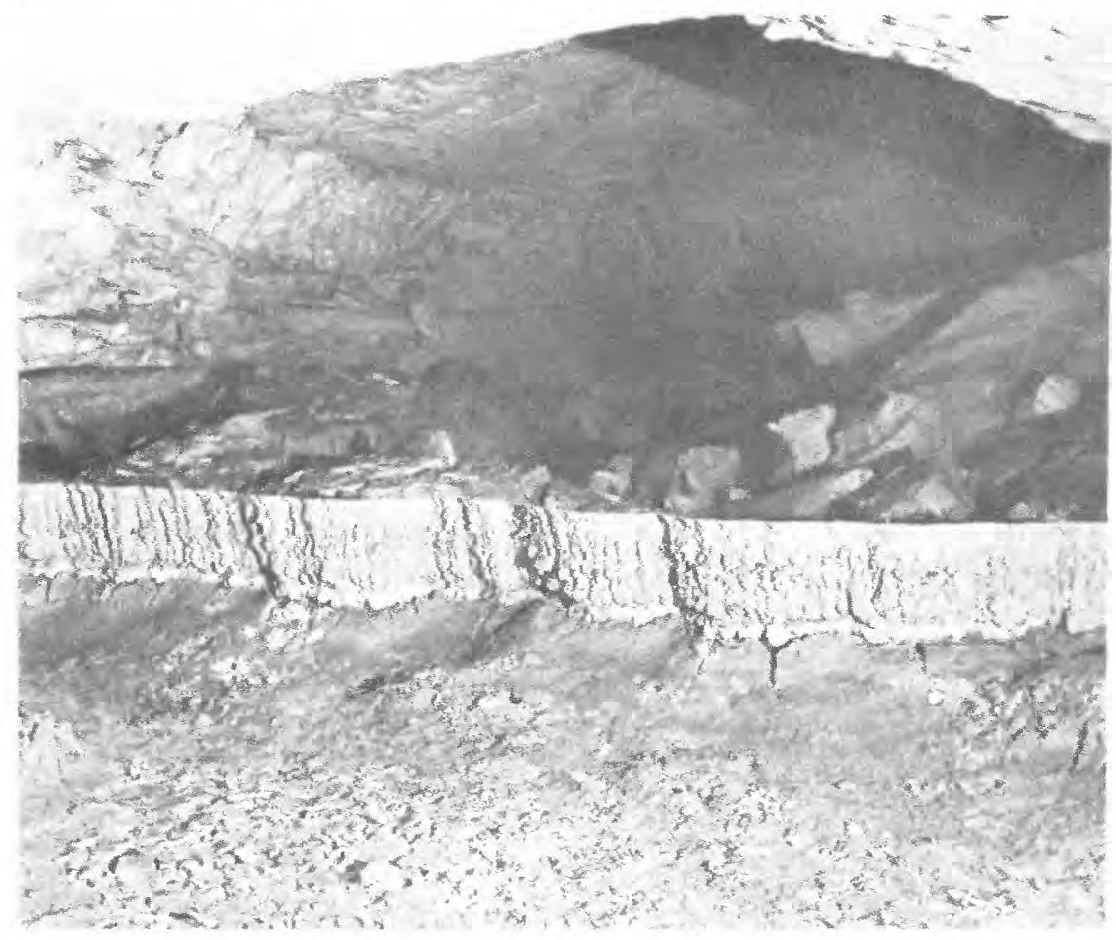

Figure 8.- Evaporite dam in New Discovery in Mammoth Cave. The dam is near the edge of Jim Lee Ridge. The sandstone capping of the ridge has been removed by erosion in the area behind the dam, and seepage enters the cave after heavy rains. High moisture conditions near here result in exquisite growths of gypsum "flowers." Photograph by W. Ray Scott.

\section{GEOLOGIC FORMATIONS AND THEIR WATER-BEARING PROPER'TIES}

The formations exposed in the area are sedimentary and consist of limestone and sandstone and some shale. They range in age from Early Mississippian through Early Pennsylvanian. The oldest rocks are limestone and shale of the Osage Series of Early Mississippian age. Above these is the Meramec Series, which includes the Warsaw, St. Louis, and Ste. Genevieve Limestones. The Chester Series in the area includes the Girkin Formation, Big Clifty Sandstone and Haney Limestone Members of the Golconda Formation, Hardinsburg Sandstone, Glen Dean Limestone, and the Leitchfield Formation. On the north side of the Green River, the Caseyville Formation of Early Pennsylvanian age caps the ridges. 111 the rocks dip about 25 feet per mile to the northwest. Only a few small faults and folds are in the area. A generalized section of the geologic formations and their water-bearing properties is given in table 1 , and the areal extent of the major geologic subdivisions is shown in figure 9. 


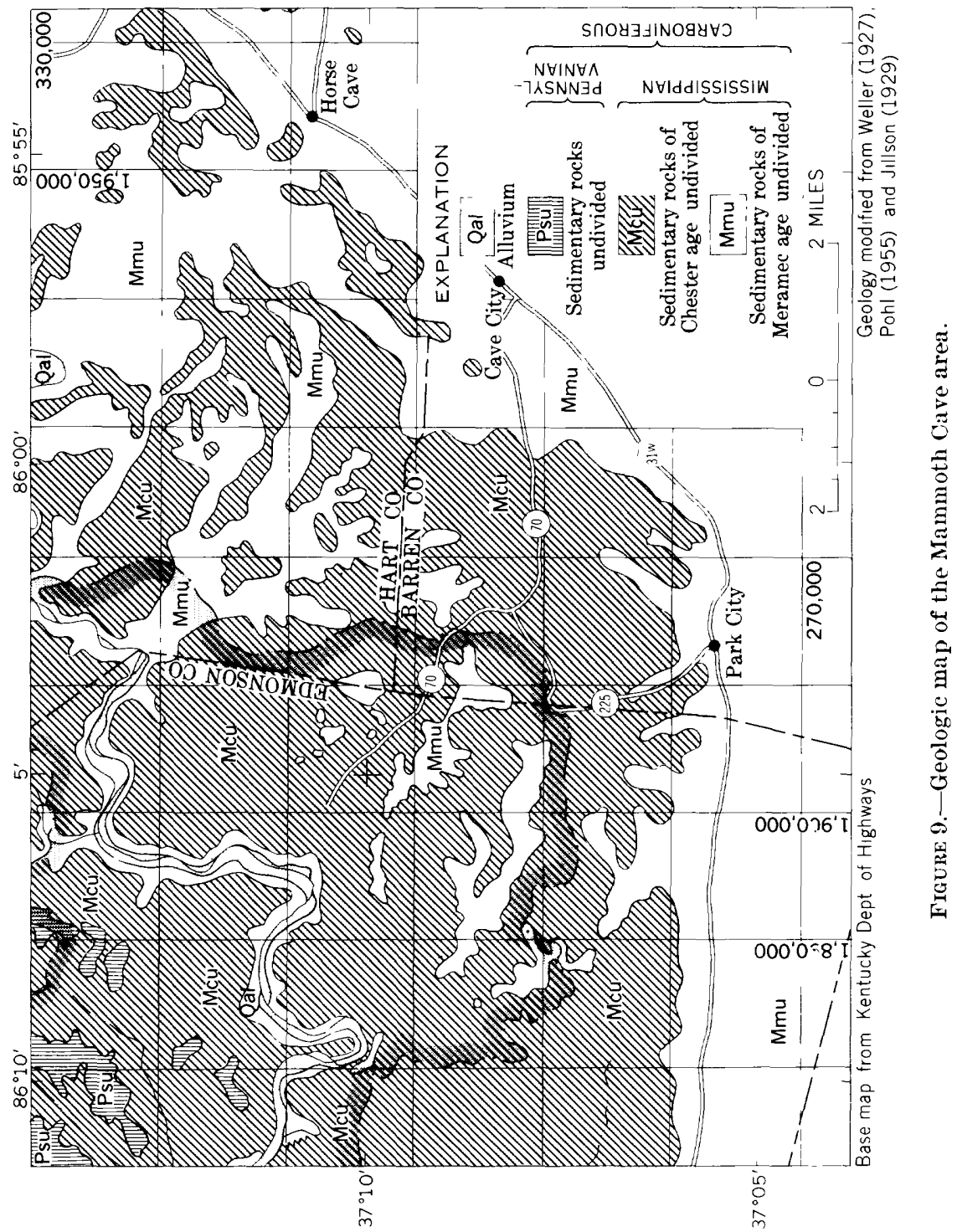


TABLE 1.-Generalized section of the geologic formations exposed in the vicinity of Mammolh Cave National Park

\begin{tabular}{|c|c|c|c|c|c|c|c|}
\hline \multirow{2}{*}{ 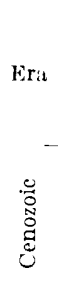 } & \multicolumn{2}{|c|}{ System } & \multirow{2}{*}{ Scries } & \multirow{2}{*}{$\begin{array}{l}\text { Subdivision } \\
\\
\text { l'leistocene and } \\
\text { Recent de- } \\
\text { posits }\end{array}$} & $\begin{array}{l}\text { Approxi- } \\
\text { mate } \\
\text { thick- } \\
\text { ness } \\
\text { (fect) }\end{array}$ & Physical character & \multirow[t]{2}{*}{$\begin{array}{l}\text { Water-bearing } \\
\text { properties }\end{array}$} \\
\hline & & E्: & & & $x 0$ & $\begin{array}{l}\text { Silt, mud, sand. Sand } \\
\text { and fine gravel in } \\
\text { tributary valleys. }\end{array}$ & \\
\hline \multirow{10}{*}{ 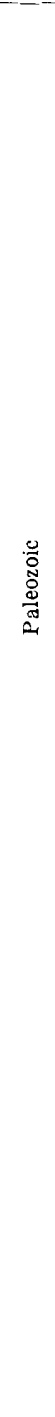 } & \multirow{10}{*}{ 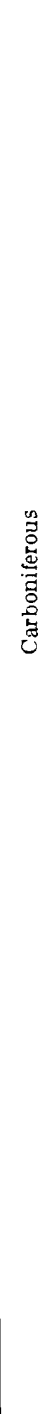 } & 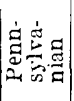 & & $\begin{array}{l}\text { Caseyville For- } \\
\text { mation }\end{array}$ & 10 & $\begin{array}{l}\text { Thick-bedded sand- } \\
\text { stone with a coarse } \\
\text { pebble conglomer- } \\
\text { ate at the base. }\end{array}$ & $\begin{array}{l}\text { Unimr ortant as an aqui- } \\
\text { fer ir this areat. }\end{array}$ \\
\hline & & \multirow{9}{*}{ 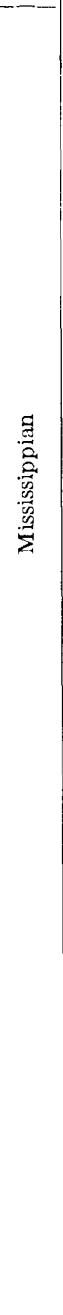 } & \multirow{6}{*}{ 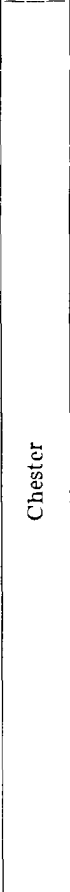 } & $\begin{array}{l}\text { Leitchficld For- } \\
\text { mation }\end{array}$ & 125 & $\begin{array}{l}\text { Shale with limestone } \\
\text { and sandstone } \\
\text { members. }\end{array}$ & $\begin{array}{l}\text { Tinimin ortant as an aqui- } \\
\text { fer ir this area. }\end{array}$ \\
\hline & & & & $\begin{array}{l}\text { (1ken I)ean } \\
\text { Limeston' }\end{array}$ & 60 & $\begin{array}{l}\text { Fine- to coarse-crys- } \\
\text { stalline gray linie- } \\
\text { stone. Shale at } \\
\text { hase of formation. }\end{array}$ & $\begin{array}{l}\text { Transmits small ruan- } \\
\text { tities of water through } \\
\text { solution channels. } \\
\text { sprirgs are concen- } \\
\text { trated at the hase of } \\
\text { the formation in west- } \\
\text { ern part of area. }\end{array}$ \\
\hline & & & & $\begin{array}{l}\text { IIardinshurg } \\
\text { Sandstone }\end{array}$ & 30 & $\begin{array}{l}\text { Medium-grained } \\
\text { erosshedded white } \\
\text { to ycllow-brown } \\
\text { sandstone and in- } \\
\text { terlaminated silt- } \\
\text { stone and shale. }\end{array}$ & $\begin{array}{l}\text { Transsits small quan- } \\
\text { tities of clear water to } \\
\text { lower formations. }\end{array}$ \\
\hline & & & & $\begin{array}{l}\text { IIaney Lime- } \\
\text { stone Mem- } \\
\text { ber of Gol- } \\
\text { conda Forma- } \\
\text { tion }\end{array}$ & 40 & $\begin{array}{l}\text { Fine- to coarse-crys- } \\
\text { talline light-gray } \\
\text { limestone. Shale } \\
\text { at base. }\end{array}$ & $\begin{array}{l}\text { Transrits moderate } \\
\text { quantities of water to } \\
\text { sprints through solu- } \\
\text { tion channels. Springs } \\
\text { and soeps are concen- } \\
\text { trated at the base of the } \\
\text { formation. }\end{array}$ \\
\hline & & & & $\begin{array}{l}\text { Big Clifty } \\
\text { Sandstone } \\
\text { Member of } \\
\text { Golconda } \\
\text { Formation }\end{array}$ & 60 & $\begin{array}{l}\text { Medium-grained } \\
\text { crossbedded light- } \\
\text { yellow to yellow- } \\
\text { hrown sandstone } \\
\text { interbedded with } \\
\text { hlack shale near } \\
\text { base. }\end{array}$ & $\begin{array}{l}\text { Transmits small quan- } \\
\text { tities of clear water to } \\
\text { lower formations. } \\
\text { Locally discharges } \\
\text { small quantities of } \\
\text { wate to springs. }\end{array}$ \\
\hline & & & & $\begin{array}{l}\text { Girkin Forma- } \\
\text { tion }\end{array}$ & 120 & $\begin{array}{l}\text { Coarse- to fine-crys- } \\
\text { talline oolitic light- } \\
\text { gray limestone. } \\
\text { Shale at base. }\end{array}$ & $\begin{array}{l}\text { Transmits small quan- } \\
\text { tities of relatively clear } \\
\text { water through solution } \\
\text { channels. Locally } \\
\text { discharges small quan- } \\
\text { tities of watc: to } \\
\text { sprin ̧̧s. }\end{array}$ \\
\hline & & & \multirow{3}{*}{ 总 } & $\begin{array}{l}\text { Ste. Genevieve } \\
\text { Limestone }\end{array}$ & 180 & $\begin{array}{l}\text { Finely crystalline } \\
\text { oolitic crossbedded } \\
\text { white to light-gray } \\
\text { limestone; contains } \\
\text { abundant chert. }\end{array}$ & \multirow{2}{*}{$\begin{array}{l}\text { Transmits large quan- } \\
\text { tities of water through } \\
\text { solut on channels. } \\
\text { Water is clear during } \\
\text { low flow but is very } \\
\text { turbit during high } \\
\text { flow. Locally dis- } \\
\text { charges large quan- } \\
\text { tities of water to } \\
\text { sprinzs. }\end{array}$} \\
\hline & & & & $\begin{array}{l}\text { St. Louis } \\
\text { Limestone }\end{array}$ & 300 & $\begin{array}{l}\text { Medium-crystalline } \\
\text { to lithographic } \\
\text { light-gray to black } \\
\text { limestone. Con- } \\
\text { tains abundant } \\
\text { chert. }\end{array}$ & \\
\hline & & & & $\begin{array}{l}\text { Warsaw Lime- } \\
\text { stone }\end{array}$ & 100 & $\begin{array}{l}\text { Medium- to coarse- } \\
\text { crystalline medium- } \\
\text { to dark-gray lime- } \\
\text { stone and inter- } \\
\text { bedded shale. }\end{array}$ & $\begin{array}{l}\text { Transmits small quan- } \\
\text { tities of water tbrougl } \\
\text { small solution chan- } \\
\text { nels. Important as a } \\
\text { relatively insoluble } \\
\text { base level. }\end{array}$ \\
\hline
\end{tabular}


TABLE 1.-Generalized section of the geologic formations exposed in the vicinity of Mammoth Cave National Park-Continued

\begin{tabular}{|c|c|c|c|c|c|c|c|}
\hline \multirow{2}{*}{ 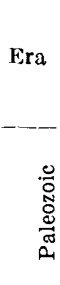 } & \multicolumn{2}{|c|}{ System } & \multirow{2}{*}{ Series } & \multirow{2}{*}{$\begin{array}{c}\text { Subdivision } \\
\begin{array}{c}\text { Fort Payne } \\
\text { Formation }\end{array}\end{array}$} & \multirow{2}{*}{$\begin{array}{c}\Delta \text { pproxi- } \\
\text { mate } \\
\text { thick- } \\
\text { ness } \\
\text { (feet) } \\
-150\end{array}$} & \multirow{2}{*}{$\begin{array}{l}\text { Physical character } \\
\text { Medium-crystalline } \\
\text { light-gray lime- } \\
\text { stone and chert } \\
\text { and ealeareous } \\
\text { shale. Grades into } \\
\text { silty limestone. }\end{array}$} & \multirow{2}{*}{$\begin{array}{l}\begin{array}{c}\text { Water-bearing } \\
\text { proporties }\end{array} \\
\text { nimportant as an } \\
\text { aquifer in this region. } \\
\text { Relatively insoluble } \\
\text { base level in sur- } \\
\text { rounding areas. }\end{array}$} \\
\hline & 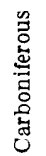 & 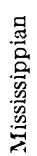 & & & & & \\
\hline
\end{tabular}

Records of wells and springs inventoried in the Mammoth Cave area are given in tables 2 and 3 . The locations of wells, springs, and dye tests are shown in figure 10.

The sequence of the geologic formations in the area and the relation of water tables and spring horizons to the formations are shown in figure 11.

Fluctuations of water levels in wells in different formations and in the Green River are shown in figures 12-16. The chemical quality of samples of water obtained from the various geologic horizons sampled and the Green River is shown in table 4. 
TABLE 2.-Records of uells in the

[Type of well: Dr, drilled: DrP, percussion drilled; Du, dug. Depth of well: Reported in feet; measured Sandstone Member of Golconda Fm.; Mh, Hardinsburg Sandstone; Mg. Girkin Fo mation; Msg, Ste. $\mathrm{H}$, hand; J, jet; Tu, turbine. Use: $\mathrm{D}$, domestic; In, industrial; $\mathrm{P}$, public supply; S, stock]

\begin{tabular}{|c|c|c|c|c|c|c|c|c|}
\hline \multirow[b]{2}{*}{ Well } & \multirow[b]{2}{*}{ Owner or name } & \multirow[b]{2}{*}{ Driller } & \multirow[b]{2}{*}{$\begin{array}{l}\text { Date } \\
\text { com- } \\
\text { plet- } \\
\text { ed }\end{array}$} & \multirow[b]{2}{*}{$\begin{array}{l}\text { Topo- } \\
\text { graphic } \\
\text { situation }\end{array}$} & \multirow{2}{*}{$\begin{array}{l}\text { Alti- } \\
\text { tude } \\
\text { above } \\
\text { sea } \\
\text { level } 1 \\
\text { (feet) }\end{array}$} & \multicolumn{3}{|c|}{ Well } \\
\hline & & & & & & Type & Depth & $\begin{array}{l}\text { Diam- } \\
\text { eter }\end{array}$ \\
\hline$S-1,879.9-295.0$ & Joe Blair... & & 1920 & $\begin{array}{l}\text { Top of } \\
\text { ridge. }\end{array}$ & 724 & $\mathrm{Du}$ & 22.8 & 26 \\
\hline $1,882.8-299.5$ & $\begin{array}{l}\text { Natl. Park } \\
\text { Service. }\end{array}$ & & 1925 & ..... do do... & 722 & $\mathrm{Du}$ & 5.5 & 26 \\
\hline $1,884.7-280.9$ & Arthur Keith & & & .... do .... & 750 & DrP & 55.2 & 6.5 \\
\hline $1,886.7-268.3$ & M. H. Wheeler & Francis Wilson. & 1949 & $\begin{array}{l}\text { Sinkhole } \\
\text { plain. }\end{array}$ & 640 & DrP & 101 & 6 \\
\hline $1,888.1-302.1$ & $\begin{array}{l}\text { Natl. Park } \\
\text { Service. }\end{array}$ & $\ldots \ldots$ & 1925 & $\begin{array}{l}\text { Top of } \\
\text { ridge. }\end{array}$ & 782 & $\mathrm{Du}$ & 18.5 & 22 \\
\hline 1,891.3-297. 9 & do & & 1925 & . do.. & 788 & Du & 17.5 & 20 \\
\hline $1,894.1-281.7$ & J. R. Hawkins.- & $\begin{array}{l}\text { Malcolm } \\
\text { Dillingham. }\end{array}$ & 1941 & $\begin{array}{l}\text { Side of } \\
\text { hill. }\end{array}$ & 560 & DrP & 180 & 8 \\
\hline $1,900.8-276.6$ & J. F. Taylor.... & & & $\begin{array}{c}\text { Sinkhole } \\
\text { plain. }\end{array}$ & 610 & DrP & 200 & 6 \\
\hline $1,902.8-297.9$ & $\begin{array}{l}\text { Natl. Park } \\
\text { Service. }\end{array}$ & & & $\begin{array}{l}\text { Side of } \\
\text { valley. }\end{array}$ & 670 & $\mathrm{Du}$ & 14.6 & 36 \\
\hline $1,903.8-293.7$ & .....do.... & $\ldots \ldots$ & 1925 & $\begin{array}{l}\text { Top of } \\
\text { ridge. }\end{array}$ & 885 & $\mathrm{Du}$ & 21.5 & 60 \\
\hline $\begin{array}{l}1,904.0-314.7 \\
1,904.8-316.3\end{array}$ & 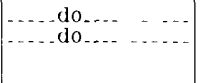 & $\begin{array}{l}\text { Malcolm } \\
\text { Dillingham. }\end{array}$ & 1953 & $\begin{array}{l}\text { Side of } \\
\text { hill. }\end{array}$ & $\begin{array}{l}860 \\
740\end{array}$ & $\begin{array}{l}\text { Du } \\
\text { DrP }\end{array}$ & 24.4 & $\begin{array}{r}32 \\
6\end{array}$ \\
\hline $1,906.4-293.3$ & ....do...... . & $\because$ & 1900 & $\begin{array}{l}\text { Top of } \\
\text { ridge. }\end{array}$ & 885 & $\mathrm{Du}$ & 23.8 & 22 \\
\hline $\begin{array}{l}1,907.4-289.6 \\
1,908.3-298.9\end{array}$ & \begin{tabular}{|c|c|} 
\\
$\ldots$
\end{tabular} & $\begin{array}{l}\text { Maloolm } \\
\text { Dillingham. }\end{array}$ & 1925 & $\mid \begin{array}{l}\mid \\
\ldots \text { do } \\
\ldots \text { do }\end{array}$ & 858 & $\begin{array}{l}\text { DrP } \\
\text { DrP }\end{array}$ & 96.6 & 7 \\
\hline $1,908.4-289.6$ & $\begin{array}{l}\text { Garner } \\
\text { IIanson. }\end{array}$ &.- & 1928 & ... do do..... & 750 & $\mathrm{Du}$ & 27.8 & 21 \\
\hline $1,909.0-285.1$ & $\begin{array}{c}\text { Diamond } \\
\text { Caverns. }\end{array}$ & . & 1925 & $\begin{array}{l}\text { Sink hole } \\
\text { plain. }\end{array}$ & 700 & DrP & 251 & 6 \\
\hline $1,909.2-267.8$ & IIazel Gray. . & $-\quad$ & 1850 & $\begin{array}{l}\text { Side of } \\
\text { hill. }\end{array}$ & 670 & $\underset{\mathrm{Du}}{\mathrm{Dr}}$ & 88 & 6 \\
\hline 1,909.5-297.6 & $\begin{array}{l}\text { Nat1. Park } \\
\text { Service. }\end{array}$ & $\begin{array}{l}\text { Maleolm } \\
\text { Dillingham. }\end{array}$ & 1938 & $\begin{array}{c}\text { Top of } \\
\text { ridge. }\end{array}$ & 873 & DrP & 500 & 8 \\
\hline $1,909.6-257.8$ & G. W. Bellamy & Bill Bailey ..... & 1900 & $\begin{array}{l}\text { Sinkhole } \\
\text { plain. }\end{array}$ & 265 & Du & 29.4 & 18 \\
\hline $1,910.2-320.1$ & $\begin{array}{l}\text { Floyd Collins } \\
\text { Crystal Cave. }\end{array}$ & $\begin{array}{l}\text { Malcolm } \\
\text { Dillingham. }\end{array}$ & 1947 & $\begin{array}{l}\text { Top of } \\
\text { ridge. }\end{array}$ & 780 & DrP & 422 & 6 \\
\hline $1,411.4-298.6$ & Glyndon Miller- & & & $\begin{array}{l}\text { Side of } \\
\text { valley }\end{array}$ & 890 & I u & 20.2 & 22 \\
\hline $1,912.5-276.7$ & $\begin{array}{l}\text { City of Park } \\
\text { City. }\end{array}$ & James Hardy & 1956 & $\begin{array}{l}\text { Sinkhole } \\
\text { plain. }\end{array}$ & 640 & I)r & 250 & 6 \\
\hline $\begin{array}{l}1,913.4-276.9 \\
1,914.0-297.7\end{array}$ & $\begin{array}{l}\text { W. L. Gardner - } \\
\text { L. A. Ferguson. }\end{array}$ & $\begin{array}{l}\text { Taylor and } \\
\text { Woodson. }\end{array}$ & $\begin{array}{l}1945 \\
194 b^{\circ}\end{array}$ & $\begin{array}{l}\text { do. } \\
\text { Top of } \\
\text { ridge. }\end{array}$ & $\begin{array}{l}640 \\
880\end{array}$ & $\begin{array}{l}\text { I)rl' } \\
\text { 1)rl' }\end{array}$ & $\begin{array}{l}225 \\
445\end{array}$ & $\begin{array}{r}10 \\
8\end{array}$ \\
\hline
\end{tabular}

See footnote at end of table. 
vicinity of Mammoth Cate National Park

in tenths of feet. Character of material: L, Iimestone; S, sandstone. Geologic horizon: Mgb, Big Clifty Genevieve Limestone; Msl, St. Louis Limestone. Type of lift: Bu, Bucket; $\mathrm{Cy}$, cylinder; E, electric;

\begin{tabular}{|c|c|c|c|c|c|c|c|c|c|}
\hline \multirow{2}{*}{\multicolumn{2}{|c|}{$\begin{array}{l}\text { Principal } \\
\text { water-bearing } \\
\text { bed }\end{array}$}} & \multirow{3}{*}{$\begin{array}{c}\text { Depth } \\
\text { of cas- } \\
\text { ing } \\
\text { (feet) }\end{array}$} & \multicolumn{2}{|c|}{ Water level } & \multirow{3}{*}{ Type of } & \multirow{3}{*}{$\begin{array}{l}\text { Ca- } \\
\text { pacity } \\
\text { of } \\
\text { pump } \\
\text { (gpm) }\end{array}$} & \multirow{3}{*}{$\begin{array}{l}\text { Re- } \\
\text { port- } \\
\text { ed } \\
\text { yield } \\
\text { (gpm) }\end{array}$} & \multirow[b]{3}{*}{ Use } & \multirow[b]{3}{*}{ Remark: } \\
\hline & & & \multirow[b]{2}{*}{$\begin{array}{l}\text { Below } \\
\text { land } \\
\text { surface } \\
\text { (feet) }\end{array}$} & \multirow[b]{2}{*}{$\begin{array}{l}\text { Date of } \\
\text { meas- } \\
\text { ure- } \\
\text { ment }\end{array}$} & & & & & \\
\hline $\begin{array}{l}\text { Cliar- } \\
\text { acter } \\
\text { of ma- } \\
\text { terial }\end{array}$ & $\begin{array}{l}\text { Geo- } \\
\text { logic } \\
\text { hori- } \\
\text { zon }\end{array}$ & & & & & & & & \\
\hline S & $\mathrm{Mgb}$ & $\cdots$ & 5.5 & $5-5-53$ & $\mathrm{Bu}, \mathrm{H}$ & & - & $\mathrm{D}, \mathrm{S}$ & Temperature $54^{\circ} \mathrm{F}$. \\
\hline $\mathrm{S}$ & $\mathrm{Mgb}$ & $\ldots$ & 3.6 & .._do.... & None & & & None & \\
\hline $\mathrm{L}$ & $\mathrm{Mg}$ & & 49.2 & $6-9-53$ & $\mathrm{Bu}, \mathrm{H}$ & & & $\mathrm{D}$ & Temperature $59^{\circ} \mathrm{F}$. \\
\hline $\mathrm{L}$ & Msd & 89 & 96 & 1949 & $\mathrm{Cy}, \mathrm{E}$ & & 10 & $\mathrm{D}$ & \\
\hline $\mathrm{S}$ & $\mathrm{Mgb}$ & $\cdots$ & 2.4 & $4-30-53$ & None & & & None & Temperature $54^{\circ} \mathrm{Y}$. \\
\hline$\stackrel{\mathrm{S}}{\mathrm{L}}$ & $\begin{array}{l}\text { Mgb } \\
\text { Msd }\end{array}$ & 8 & $\begin{array}{ll}3.8 \\
150\end{array}$ & $\mid \begin{array}{c}\text { do } \\
1941\end{array}$ & $\begin{array}{l}\text { None } \\
\text { Cy, E }\end{array}$ & & & None & \\
\hline $\mathrm{L}$ & Msd & & & & $\mathrm{Cy}, \mathrm{E}$ & & & $\mathrm{P}$ & \\
\hline $\mathrm{L}$ & $\mathrm{Mg}$ & None & 13.2 & $5-8-53$ & None & & & None & $\begin{array}{l}\text { Water flows in at } 10 \mathrm{ft} \\
\text { depth, out at } 13.2 \mathrm{ft} \\
\text { through solution open- } \\
\text { ings. }\end{array}$ \\
\hline 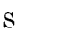 & $\mathrm{Mgb}$ & None & 2.4 & $5-6-53$ & None & & & None & Temperature $58^{\circ} \mathrm{r}$. \\
\hline $\mathrm{S}$ & $\mathrm{Mh}_{\mathbf{l}}$ & None & $\begin{array}{r}16.0 \\
303.3\end{array}$ & - do-22-53 & $\begin{array}{l}\text { None } \\
\text { Cy, E }\end{array}$ & & 10 & $\underset{\mathrm{P}}{\text { None }}$ & $\begin{array}{l}\text { Rate of yield mea:ured Jun e } \\
\text { 22, 1956. Emergency pub- } \\
\text { lic supply for Mammoth } \\
\text { Cave National Park. } \\
\text { Temperature } 56^{\circ} \mathrm{F} \text {. }\end{array}$ \\
\hline S & $\mathrm{Mgb}$ & None & 3.2 & $4-30-53$ & None & & & None & $\begin{array}{l}\text { Automatic record } 3 \text { installed } \\
\text { May } 13,1953 \text {. }\end{array}$ \\
\hline $\begin{array}{l}\mathrm{L} \\
\mathrm{L}\end{array}$ & $\begin{array}{l}\text { Mg } \\
\text { Msg }\end{array}$ & 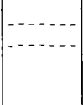 & 81.3 & $5-6-53$ & $\begin{array}{l}\text { None } \\
\text { None }\end{array}$ & & & $\begin{array}{l}\text { None } \\
\text { None }\end{array}$ & $\begin{array}{l}\text { Do. } \\
\text { Well used to carry electric } \\
\text { wires into Mam moth } \\
\text { Cave. }\end{array}$ \\
\hline $\mathrm{L}$ & $\mathrm{Mg}$ & $\cdots$ & 27.3 & $5-6-53$ & $\mathrm{~J}, \mathrm{E}$ & & & $\mathrm{D}$ & \\
\hline $\mathrm{L}$ & Msd & 200 & 225 & 1948 & $\mathrm{Cy}, \mathrm{E}$ & & 92 & $\mathrm{P}$ & \\
\hline $\mathrm{L}$ & Msd & 44 & 84 & 1948 & J, E & & & $\mathrm{D}, \mathrm{S}$ & $\begin{array}{l}\text { Well formed by d 'gging a } \\
\text { hole into a cave and put- } \\
\text { ting the pump in a reser- } \\
\text { voir constructed in the } \\
\text { cave. Dug wel' caved in } \\
1948 \text { and was re trilled. }\end{array}$ \\
\hline L & Msl & & 419.7 & $6-10-53$ & $13 u, 1 I$ & & & None & $\begin{array}{l}\text { Former public suoply for } \\
\text { Civilian Conservation } \\
\text { Corps Camp. Automatic } \\
\text { recorder installed May } \\
22,1953 \text {. Temperature } \\
58^{\circ} \mathrm{F} \text {. } \\
\text { Temperature } 58^{\circ} \mathrm{F} \text {. }\end{array}$ \\
\hline $\mathbf{L}$ & Msg & 40 & 422 & 1947 & $\mathrm{Cy}, \mathrm{E}$ & & & $\mathbf{P}$ & $\begin{array}{l}\text { Believed to obtain water } \\
\text { from Pike Sprirg. }\end{array}$ \\
\hline$S$ & $\mathrm{Mgb}$ & 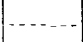 & 16.4 & $5-12-53$ & None & & & None & \\
\hline $\mathrm{L}$ & Msl & 180 & 225 & 1956 & $\mathrm{Tu}, \mathrm{E}$ & 50 & 50 & $\mathbf{P}$ & Temperature $59^{\circ} \mathrm{F}$. \\
\hline $\begin{array}{l}\mathrm{L} \\
\mathrm{I}\end{array}$ & $\begin{array}{l}\text { Msl } \\
\text { Msg }\end{array}$ & $\begin{array}{r}100 \\
20\end{array}$ & $\begin{array}{l}159.0 \\
410\end{array}$ & $\begin{array}{r}8-20-52 \\
1946\end{array}$ & $\begin{array}{l}\mathrm{Tu}, \mathrm{E} \\
\mathrm{Cy}, \mathrm{E}\end{array}$ & 60 & $\begin{array}{l}60 \\
35\end{array}$ & $\begin{array}{l}\mathrm{P} \\
\mathrm{D}\end{array}$ & Temperature $59^{\circ} \mathbf{F}$. \\
\hline
\end{tabular}


TABLE 2.-Records of wells in the

\begin{tabular}{|c|c|c|c|c|c|c|c|c|}
\hline \multirow[b]{2}{*}{ Well } & \multirow[b]{2}{*}{ Owner of name } & \multirow[b]{2}{*}{ Driller } & \multirow[b]{2}{*}{$\begin{array}{l}\text { Date } \\
\text { com- } \\
\text { plet- } \\
\text { ed }\end{array}$} & \multirow[b]{2}{*}{$\begin{array}{l}\text { Topo- } \\
\text { graphic } \\
\text { situation }\end{array}$} & \multirow{2}{*}{$\begin{array}{l}\text { Alti- } \\
\text { tude } \\
\text { above } \\
\text { sea } \\
\text { level } 1 \\
\text { (feet) }\end{array}$} & \multicolumn{3}{|c|}{ Well } \\
\hline & & & & & & T.rpe & Depth & $\begin{array}{c}\text { Diam- } \\
\text { eter }\end{array}$ \\
\hline S-1,915.9-292.0 & $\begin{array}{l}\text { Rock Cabin } \\
\text { Camp. }\end{array}$ & $\begin{array}{c}\text { Charley } \\
\text { Downey. }\end{array}$ & & ... do do....... & 910 & DrP & 495 & 6 \\
\hline $1,919.9-288.7$ & L. A. Ferguson & $\begin{array}{l}\text { Wilson and } \\
\text { Wilson. }\end{array}$ & 1952 & . do & 770 & DrP & 1,350 & 14 \\
\hline $1,922.8-277.1$ & Emit Coomer & & 1937 & Sinkhole & 720 & DrP & 220 & 6 \\
\hline $\begin{array}{l}1,922.9-276.1 \\
1,932.8-281.9\end{array}$ & Ernest Dossey & Pall Dean & $\begin{array}{l}1913 \\
1952\end{array}$ & Side of & $\begin{array}{l}700 \\
750\end{array}$ & $\begin{array}{l}\text { Du } \\
\text { DrP }\end{array}$ & $\begin{array}{c}53.4 \\
180\end{array}$ & $\begin{array}{r}40 \\
6\end{array}$ \\
\hline 1,938.2-289.9 & Roscoe Atwell... & Claude Morris & 1953 & $\begin{array}{l}\text { Sinkhole } \\
\text { plain. }\end{array}$ & 610 & $\mathrm{Dr} \cdot \mathrm{P}$ & 141.0 & 6 \\
\hline $1,939.2-293.8$ & $\begin{array}{l}\text { Town of Cave } \\
\text { City. }\end{array}$ & $\begin{array}{l}\text { Acme Well } \\
\text { Drillers. }\end{array}$ & 1949 & ... do do...... & 640 & DrP & 145 & 10 \\
\hline 1,943.3-295.8 & W. G. Proffitt & $\begin{array}{l}\text { Woods and } \\
\text { Forest. }\end{array}$ & 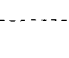 & .... do & 620 & DrP & 188.8 & 6 \\
\hline $\begin{array}{l}1,945.7-282.9 \\
1,947.0-317.7\end{array}$ & $\begin{array}{l}\text { Leron Reynolds- } \\
\text { Erwin R. Pohl-- }\end{array}$ & $\begin{array}{c}\text { Henderson } \\
\text { Carpenter. }\end{array}$ & 1921 & $\begin{array}{l}\text { Side of } \\
\text { valley. }\end{array}$ & $\begin{array}{l}690 \\
700\end{array}$ & $\begin{array}{l}\text { DrP } \\
\text { DrP }\end{array}$ & 250 & $\begin{array}{l}8 \\
8\end{array}$ \\
\hline $1,950.5-302.5$ & V. W. McCoy - & . & 1947 & $\begin{array}{l}\text { Sinkhole } \\
\text { plain. }\end{array}$ & 630 & DrP & 190 & 6 \\
\hline $1,951.4-282.2$ & H. H. Barlow, & $\begin{array}{l}\text { Malcom } \\
\text { Dillingham. }\end{array}$ & 1940 & ...do.... & 700 & DrP & 128 & 6 \\
\hline $1,952.3-304.6$ & $\begin{array}{l}\text { Hart County } \\
\text { Creameries. }\end{array}$ & Francis Wilson & 1947 & $\begin{array}{l}\text { Sinkhole } \\
\text { plain. }\end{array}$ & 620 & DrP & 270 & 8 \\
\hline $1.953 .7 \cdot 307.0$ & $\begin{array}{l}\text { Town of Horse } \\
\text { Cave. }\end{array}$ & & & ... do & & Dr & 315 & 8 \\
\hline $1,953.4-307.4$ & .... do... & & & ... do & & Dr & 265 & 8 \\
\hline $1,954.6-292.1$ & D. D. Higgaso_- & & 1952 & . do & 680 & DrP & 247 & 7 \\
\hline $1,955.4-283.6$ & L. M. Wilson. - & Tom Walters. & 1946 & ... do...... & 700 & DrP & 170 & 6 \\
\hline
\end{tabular}

1 Altitudes from U.S. Geol. Survey 71/2-minute topographic quadrangles: Horse Cane, Glasgow North , 
vicinity of Mammoth Cavc National Park-Continued

\begin{tabular}{|c|c|c|c|c|c|c|c|c|c|}
\hline \multirow{2}{*}{\multicolumn{2}{|c|}{$\begin{array}{l}\text { Principal } \\
\text { water-bearing } \\
\text { bed }\end{array}$}} & \multirow{3}{*}{$\begin{array}{l}\text { Depth } \\
\text { of cas- } \\
\text { ing } \\
\text { (feet) }\end{array}$} & \multicolumn{2}{|c|}{ Water level } & \multirow{3}{*}{$\begin{array}{c}\text { Type of } \\
\text { lift }\end{array}$} & \multirow{3}{*}{$\begin{array}{l}\text { Ca- } \\
\text { pacity } \\
\text { of } \\
\text { pump } \\
\text { (gpm) }\end{array}$} & \multirow{3}{*}{$\begin{array}{l}\text { Re- } \\
\text { port- } \\
\text { ed } \\
\text { yield } \\
(\mathrm{gpm})\end{array}$} & \multirow{3}{*}{ Use } & \multirow{3}{*}{ Remarks } \\
\hline & & & & & & & & & \\
\hline $\begin{array}{l}\text { Char- } \\
\text { acter } \\
\text { of ma- } \\
\text { terial }\end{array}$ & $\begin{array}{l}\text { Geo- } \\
\text { logic } \\
\text { hori- } \\
\text { zon }\end{array}$ & & $\begin{array}{l}\text { Below } \\
\text { land } \\
\text { surface } \\
\text { (feet) }\end{array}$ & $\begin{array}{l}\text { Date or } \\
\text { meas- } \\
\text { ure- } \\
\text { ment }\end{array}$ & & & & & \\
\hline $\mathrm{L}$ & Msg & 20 & 450 & $\ldots$ & $\mathrm{Cy}, \mathrm{E}$ & & & $\mathrm{P}$ & \\
\hline $\mathrm{L}$ & Msg & None & 200 & 1952 & None & & & None & $\begin{array}{l}\text { Oil test well. Plugged at } \\
200 \mathrm{ft} \text { for water well. Caved } \\
\text { to } 160 \mathrm{ft} \text {, no water in caved } \\
\text { hole. }\end{array}$ \\
\hline $\mathrm{L}$ & Msl & & 200 & & $\mathrm{Cy}, \mathrm{E}$ & & & $\mathrm{D}, \mathrm{S}$ & \\
\hline$\underset{\mathrm{L}}{\mathrm{L}}$ & $\begin{array}{l}\text { Msl } \\
\text { Msl }\end{array}$ & $\begin{array}{r}\text { None } \\
20\end{array}$ & $\begin{array}{l}50.0 \\
160\end{array}$ & $\begin{array}{r}6-9-53 \\
1952\end{array}$ & $\begin{array}{l}\text { None } \\
\mathrm{Cy}, \mathrm{E}\end{array}$ & 12 & 12 & $\begin{array}{l}\text { None } \\
\mathrm{D}, \mathrm{S}\end{array}$ & \\
\hline L & Ms] & 75 & 103.6 & $6-4-53$ & None & & & None & \\
\hline $\mathbf{L}$ & Msl & & 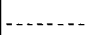 & & $\mathrm{Tu}, \mathrm{E}$ & - & 300 & $\mathrm{P}$ & Temperature $60^{\circ} \mathrm{F}$. \\
\hline $\mathrm{L}$ & Msl & & 102.0 & $6-3-53$ & None & & & None & \\
\hline $\mathrm{L}$ & Msl & & & & $\mathrm{Cy}, \mathrm{H}$ & & & $\mathrm{D}, \mathrm{s}$ & Temperature $59^{\circ} \mathrm{F}$. \\
\hline $\mathbf{L}$ & Msl & 114 & 220 & 1941 & $\mathrm{Cy}, \mathrm{E}$ & 4.5 & 4.5 & $P^{\prime}$ & Temperature $58^{\circ} \mathrm{F}$. \\
\hline $\mathrm{L}$ & Msl & & $\ldots$. & & Cy, E & & & $\mathrm{P}$ & Temperature $57^{\circ} \mathrm{F}$. \\
\hline $\mathrm{L}$ & Msl & & 90 & 1940 & $\mathrm{Cy}, \mathrm{E}$ & & & $\mathrm{D}, \mathrm{s}$ & $\begin{array}{l}\text { Well yields } 30 \text { gal and can } \\
\text { then be pumped dry with } \\
\text { a hand pump. }\end{array}$ \\
\hline $\mathbf{L}$ & Ms1 & 144 & & & Tu, E & 35 & 35 & In & $\begin{array}{l}\text { Gas at } 285 \mathrm{ft} \text {, drilled to } 375 \\
\mathrm{ft} \text {; well plugged to } 270 \mathrm{ft} \\
40 \mathrm{ft} \text { drawdows after } 5 \\
\text { days pumping. Temper- } \\
\text { ature } 57^{\circ} \mathrm{F} \text {. }\end{array}$ \\
\hline $\mathbf{L}$ & Ms1 & & 142 & 1947 & $\mathbf{T u}, \mathbf{E}$ & 150 & 146 & $\mathrm{P}$ & $\begin{array}{l}\text { 1.5 ft. drawdown after } 24 \mathrm{hr} \\
\text { pumping repor+ed. } \\
\text { Temperature } 5 f^{\circ} \mathrm{F} \text {. }\end{array}$ \\
\hline $\mathbf{L}$ & Ms1 & $\ldots$ & 186 & 1946 & Tu, E & 105 & 85 & $\mathrm{P}$ & $\begin{array}{l}35 \mathrm{ft} \text { drawdown after } 10 \\
\text { days pumping reported. } \\
\text { Temperature } 56^{\circ} \mathrm{F} \text {. }\end{array}$ \\
\hline $\mathrm{L}$ & Ms1 & 27 & 243 & 1952 & $\mathrm{Cy}, \mathrm{E}$ & & & $\mathrm{D}, \mathrm{S}$ & $\begin{array}{l}\text { Well has yielded } 2 \text { in. } \\
\text { stream of water con- } \\
\text { tinuously for } 12 \mathrm{hr} \text {. }\end{array}$ \\
\hline $\mathbf{L}$ & Ms1 & 30 & 155 & 1946 & Cy. E & & $1 / 2$ & $\mathrm{D}$ & $\begin{array}{l}\text { Well pumps dry in a few } \\
\text { minutes. Gas encoun- } \\
\text { tered at } 450 \mathrm{ft} \text {, and } 650 \\
\text { it; well pluggec back to } \\
170 \mathrm{ft} \text {. }\end{array}$ \\
\hline
\end{tabular}

Mammoth Cave, and Rhoda. 
TABLE 3.- Records of springs in the vicinity

[Character of material: 1, limestone; s, sandstone. ( icologic horizon: Mgb, Big Clifty Sindstone Member: mublic

\begin{tabular}{|c|c|c|c|c|c|c|}
\hline \multirow[b]{2}{*}{ springr } & \multirow[b]{2}{*}{ Owner or name } & \multirow{2}{*}{$\begin{array}{l}\text { Type of } \\
\text { spring }\end{array}$} & \multirow{2}{*}{$\begin{array}{l}\text { Topograplic } \\
\text { situation }\end{array}$} & \multirow{2}{*}{$\begin{array}{l}\text { Altitude } \\
\text { above } \\
\text { sea } \\
\text { level }{ }^{1} \\
\text { (feet) }\end{array}$} & \multicolumn{2}{|c|}{$\begin{array}{l}\text { Principal water- } \\
\text { hearing bed }\end{array}$} \\
\hline & & & & & $\left|\begin{array}{c}\text { Cl aracter } \\
\text { of } \\
\text { material }\end{array}\right|$ & $\begin{array}{l}\text { Geologic } \\
\text { horizon }\end{array}$ \\
\hline $\begin{array}{cc}- & - \\
S-1.881 .0-303.2\end{array}$ & Nutl Park Service & $-\quad-\cdots-$ & Base of bluf & 430 & - & $-\cdots \cdots$ \\
\hline $1.88: 2.2-297.1$ & $\ldots$ do & Tubular & Bottom of sink- & 427 & $\mathrm{~L}$ & Msg \\
\hline $\begin{array}{l}1.884 .0-304.7 \\
1,886.9-287.2\end{array}$ & Willie [Doyle - & $\begin{array}{l}\text {-do } \\
\text { do do...... }\end{array}$ & $\begin{array}{l}\text { hole. } \\
\text { Side of valley _... } \\
\text { d do }\end{array}$ & $\begin{array}{l}430 \\
600\end{array}$ & $\begin{array}{l}\mathrm{I} \\
\mathrm{L}\end{array}$ & $\begin{array}{l}\text { Msg } \\
\text { Msg }\end{array}$ \\
\hline $1,893.0-283.3$ & Otis Locke ... & do..... & $\begin{array}{l}\text { Bottom of } \sin \mathrm{k} \text { - } \\
\text { hole. }\end{array}$ & 450 & $\mathrm{~L}$ & Msg \\
\hline $\begin{array}{l}1,893.2-283.7 \\
1,895.5-308.1 \\
1,895.5-311.0 \\
1,902.9-314.2\end{array}$ & $\begin{array}{l}\text { Natl. P'ark Service } \\
\text { - do do.... } \\
\text { - do.... }\end{array}$ & $\begin{array}{l}\text { - do } \\
\text { do do....... } \\
\text { do..... } \\
\text { dlo }\end{array}$ & $\begin{array}{l}\text { Side of sinkhole } \\
\text { Side of valley } \\
\text {-do..... } \\
\text {-do }\end{array}$ & $\begin{array}{l}500 \\
420 \\
425 \\
740\end{array}$ & $\begin{array}{l}\text { l. } \\
\text { L. } \\
\text { l., } \\
\text { I. }\end{array}$ & $\begin{array}{l}\text { Msg } \\
\text { Msg } \\
\text { Msg } \\
M g h\end{array}$ \\
\hline $1,904.8-316.2$ & .. do_..... & -.. do_.... & _ & 738 & s & $\mathrm{Mgb}$ \\
\hline $1.911 .0-3 \div 0.9$ & Floyd Collins Crystal & - . cho... & Base of hluff. & 430 & 1. & $\mathrm{Msl}$ \\
\hline $\begin{array}{l}1,913.8-314.1 \\
1.940 .7-291.6\end{array}$ & $\begin{array}{l}\text { John Buck ingham } \\
\text { Louisville \& Nash- } \\
\text { ville Railroad Co. }\end{array}$ & $\begin{array}{l}\text {-do } \\
\text {-do..... }\end{array}$ & $\begin{array}{l}\text { Side of valley - } \\
\text { Sinkhole plain - }\end{array}$ & 795 & is & $\begin{array}{l}\mathrm{Mgh} \\
\mathrm{Msl}\end{array}$ \\
\hline $\begin{array}{l}1.946 .1-330.2 \\
1.954 .6-307.9\end{array}$ & $\begin{array}{l}\text { J. L. Garvin } \\
\text { Mrs. II. B. Thomias. }\end{array}$ & 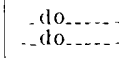 & $\begin{array}{l}\text { Base of bluff } \\
\text { Sinkhole plain - }\end{array}$ & $-\cdots$ & $\begin{array}{l}\mathrm{L} \\
\mathrm{L}\end{array}$ & $\begin{array}{l}\text { Msg } \\
\text { Msl }\end{array}$ \\
\hline $1,95.5 .1-281.6$ & Salem Baptist Church. & .... do_.... & $\begin{array}{l}\text { Bottom of sink. } \\
\text { hole. }\end{array}$ & 620 & I & MsL \\
\hline
\end{tabular}

1 Altitudes from L.S. Geol. Survey $7 / 2$-minute topographic quadrangles: IIorse Cave, Glasgow North, 
of Mammoth Cave National Park:

Mgh, I Ianey Limestone Member; Mssr, Ste. Genevieve Limestone; Msl, St. Louis Limestone. Use: P, supply]

\begin{tabular}{|c|c|c|c|c|c|c|}
\hline Improvements & $\begin{array}{l}\text { l)epend- } \\
\text { ability }\end{array}$ & $\begin{array}{l}\text { Yicld: } \\
\text { Esti- } \\
\text { mated } \\
\text { rate of } \\
\text { flow } \\
\text { (gpm) }\end{array}$ & $\begin{array}{l}\text { Date of } \\
\text { estimate }\end{array}$ & I'se & $\begin{array}{l}\text { Tem- } \\
\text { pera- } \\
\text { ture } \\
\left({ }^{\circ} \mathrm{F}\right)\end{array}$ & Remarks \\
\hline None........ & -1- - - - & 50,000 & $5-18-53$ & $-\quad \ldots$. & 58 & $\begin{array}{l}\text { Outlet is covered by Green } \\
\text { River. }\end{array}$ \\
\hline None... . ... & Never dry & 25,000 & $4-30-53$ & $\ldots \ldots$ & 56 & \\
\hline None........... & & 10,000 & $5-29-53$ & $\ldots$ & 56 & \\
\hline $\begin{array}{l}\text { Concrete col- } \\
\text { lecting pond. }\end{array}$ & Never dry - & 50 & $5-7-53$ & $\ldots$ & 55 & \\
\hline None. ......... & .... do....... & 20,000 & $5-26-53$ & $\ldots \ldots$ & 59 & $\begin{array}{l}\text { Flow tlirough bottom of sink- } \\
\text { hole was formerly used to } \\
\text { turn a floating water wheel } \\
\text { for a mill. }\end{array}$ \\
\hline Outlet pipe & -... dio. & 100 & $5-26-53$ & - . - & 56 & \\
\hline $\begin{array}{l}\text { None - } \\
\text { None. }\end{array}$ & -... do . . & $\begin{array}{l}400 \\
300\end{array}$ & $(i-1-53$ & $\ldots$ & $\begin{array}{l}56 \\
56\end{array}$ & Outlet for Echo River. \\
\hline $\begin{array}{l}\text { Fnclosure, res- } \\
\text { ervoir pumps. }\end{array}$ & Never dry & $\begin{array}{l}300 \\
900\end{array}$ & $4-29-53$ & $l^{\prime}$ & 5.5 & $\begin{array}{l}\text { Source of public water supply } \\
\text { for Mammoth Cave Na- } \\
\text { tional Park. Inadequate } \\
\text { during dry summers. }\end{array}$ \\
\hline _.............. & -... (10...... & 300 & -110 & $\mathrm{I}^{\prime}$ & 55 & $\begin{array}{l}\text { Source of supplemental public } \\
\text { water supply for Mammoth } \\
\text { Cave National Park during } \\
\text { dry weather. }\end{array}$ \\
\hline None - $\ldots \ldots$ & $-\cdots \quad-\cdots \quad-\cdots$ & $100-30,000$ & $9-14-59$ & $1^{\prime}$ & 55 & \\
\hline $\begin{array}{l}\text { None.. } \\
\text { Pump. }\end{array}$ & Never dry & $200-500$ & $\begin{array}{l}5-6-53 \\
4-26-51\end{array}$ & $\begin{array}{l}\text { None } \\
\text { None }\end{array}$ & 54 & No longer used by railroad. \\
\hline $\begin{array}{l}\text { None } \\
\text { Dam, pumps, } \\
\text { walks. }\end{array}$ & Never dry & $\begin{array}{r}8,000 \\
35,000\end{array}$ & $\begin{array}{l}5-27-53 \\
5-28-53\end{array}$ & $\begin{array}{l}\text { None } \\
\text { None }\end{array}$ & $\begin{array}{l}58 \\
58\end{array}$ & $\begin{array}{l}\text { Former source of public water } \\
\text { supply for Horse Cave. } \\
\text { Abandoned becaluse of feeal } \\
\text { pollution. }\end{array}$ \\
\hline None - & & 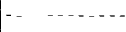 & $-\cdots$ & None & -....... & \\
\hline
\end{tabular}

Mammoth Cave, and Rhoda. 


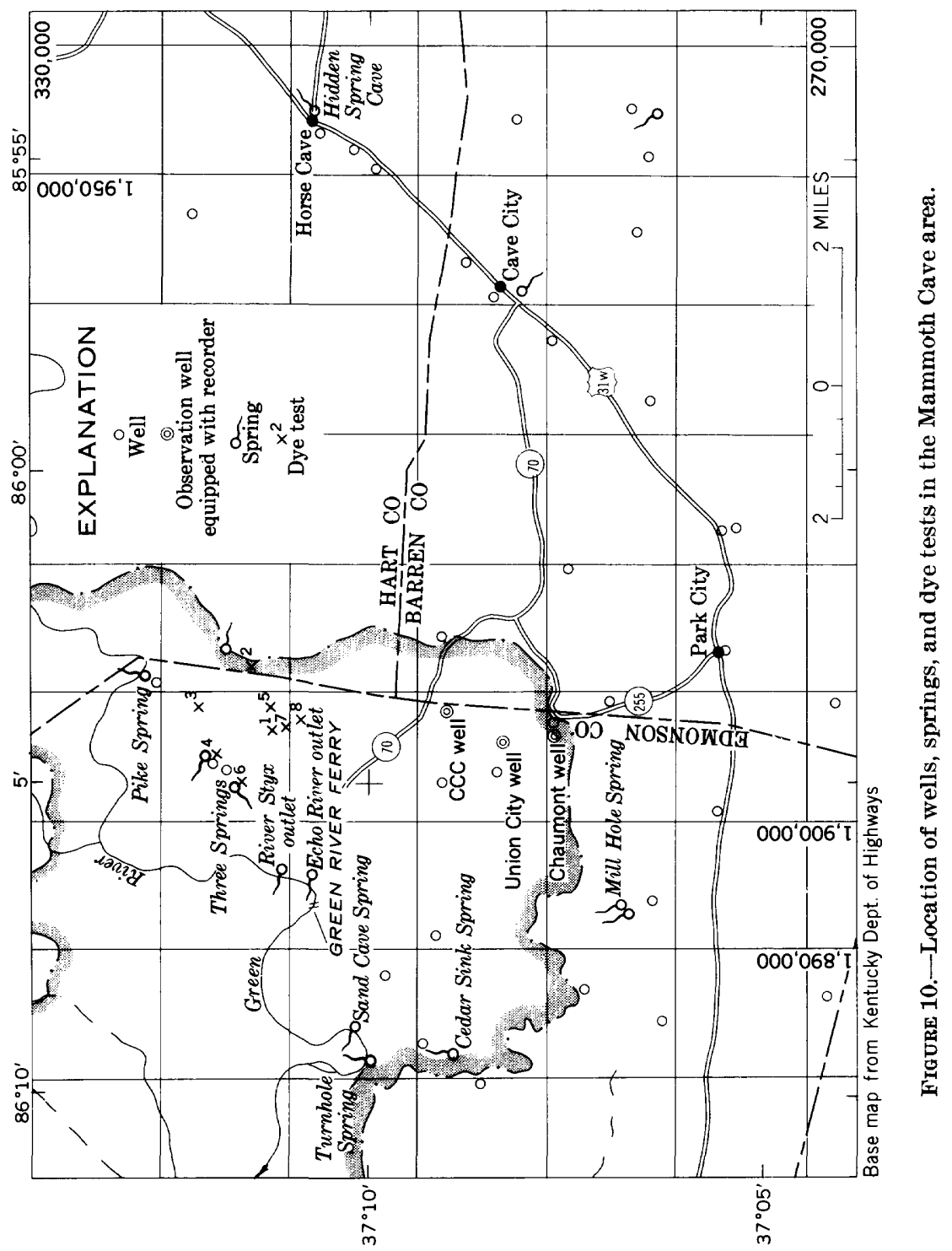


PALEOZOIC ERA

\section{MISSISSIPPIAN SYSTEM}

OSAGE SERIES

\section{Fort Payne Formation}

The Fort Payne Formation, the oldest rock exposed, underlies the entire area and is about 150 feet thick. In its outcrop area to the south and east, the Fort Payne consists of alternating impurs limestone and shale and extensive beds of chert. The formation ranges in color from light to dark gray. The limestone is mostly nedium crystalline and light gray. In many localities it is silty and grades into calcareous shale. The chert is blocky and light bluish gray. The formation weathers slowly to a medium gray, and the bads of chert and siltstone form small resistant benches on hill slopes. In the area in which it crops out, good exposures are numerous.

In the report area, the Fort Payne is not known to yield water to wells. Farther to the south it yields small amounts of water to domestic wells and supplies small springs that are suitable for stock and domestic use. In general, the resistant beds of shale and siltstone prevent rapid downward percolation of water, the limestone bads are neither thick enough nor soluble enough to have large solution conduits formed. The importance of the Fort Payne in the perimeter of the Mammoth Cave region is that on the south and west, it and tho overlying Warsaw Limestone of Meramec age form a relatively insoluble base level below which the solution action that prevails in the higher limestone formations cannot persist. Accordingly, in the areas in which the Fort Payne Formation is close to the surface, drainage is conducted by normal streams.

\section{MERAMEC SERIES}

\section{Warsaw Limestone}

The Warsaw Limestone is about 100 feet thick in this area. It consists of medium- to coarse-crystalline medium- to dark-gray limestone and interbedded shale. In some places the limestone grades into siltstone or a silty limestone. Numerous geodes, in many loalities and at several horizons, are characteristic of the formation. It is moderately resistant to weathering and supports steep slopes. Exposures are good in many places. The residual soil dereloped on the Warsaw is generally a reddish silty clay. Geodes generally are numerous in the soil.

In the southern and eastern part of the Mammoth Cave area where it is exposed at the surface, the Warsaw Limestone is not a good source of water. Although south of this area it yields domestic supplies to wells and springs, no large supplies are obtained from it. No effort was made to inventory all the wells in the area, and it is presumed that 


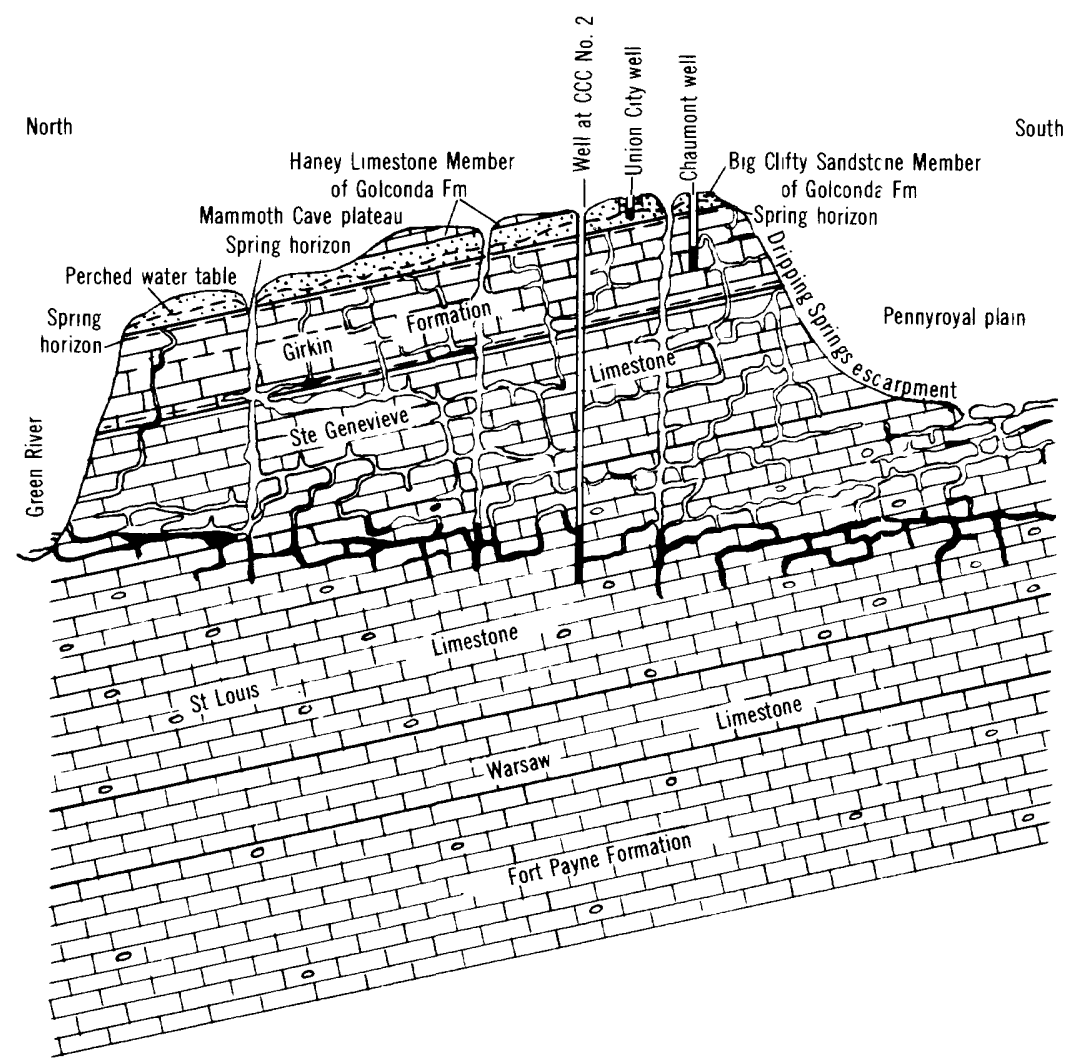

Figure 11.-Diagrammatic section through the Mammoth Cave plateau.

some wells obtain water from the Warsaw. It is important to the hydrology of the region because it generally is much less soluble than the St. Louis Limestone that overlies it. The surface streams in the southern and eastern part of the area flow on the uppor part of the Warsaw. Near the point where they flow onto the St. Louis Limestone, they enter large cavernous passageways and flow underground. I few sinkholes are developed in the Warsaw, but the "reas of major sinkhole development are those that are underlain by younger formations.

\section{St. Louis Limestone}

The St. I touis Limestone is about 300 feet thick in the Mammoth Cave area. It is composed predominantly of relatively pure limestone. The upper part ranges from lithographic to medium-crystalline light-gray limestone. The lower part is very fine crystalline and gray to black. Both parts contain abundant chert and a few thin shale layers. The limestone weathers to a bright red clay containing numerous blocks of chert. The St. I ouis Limestone underlies the 

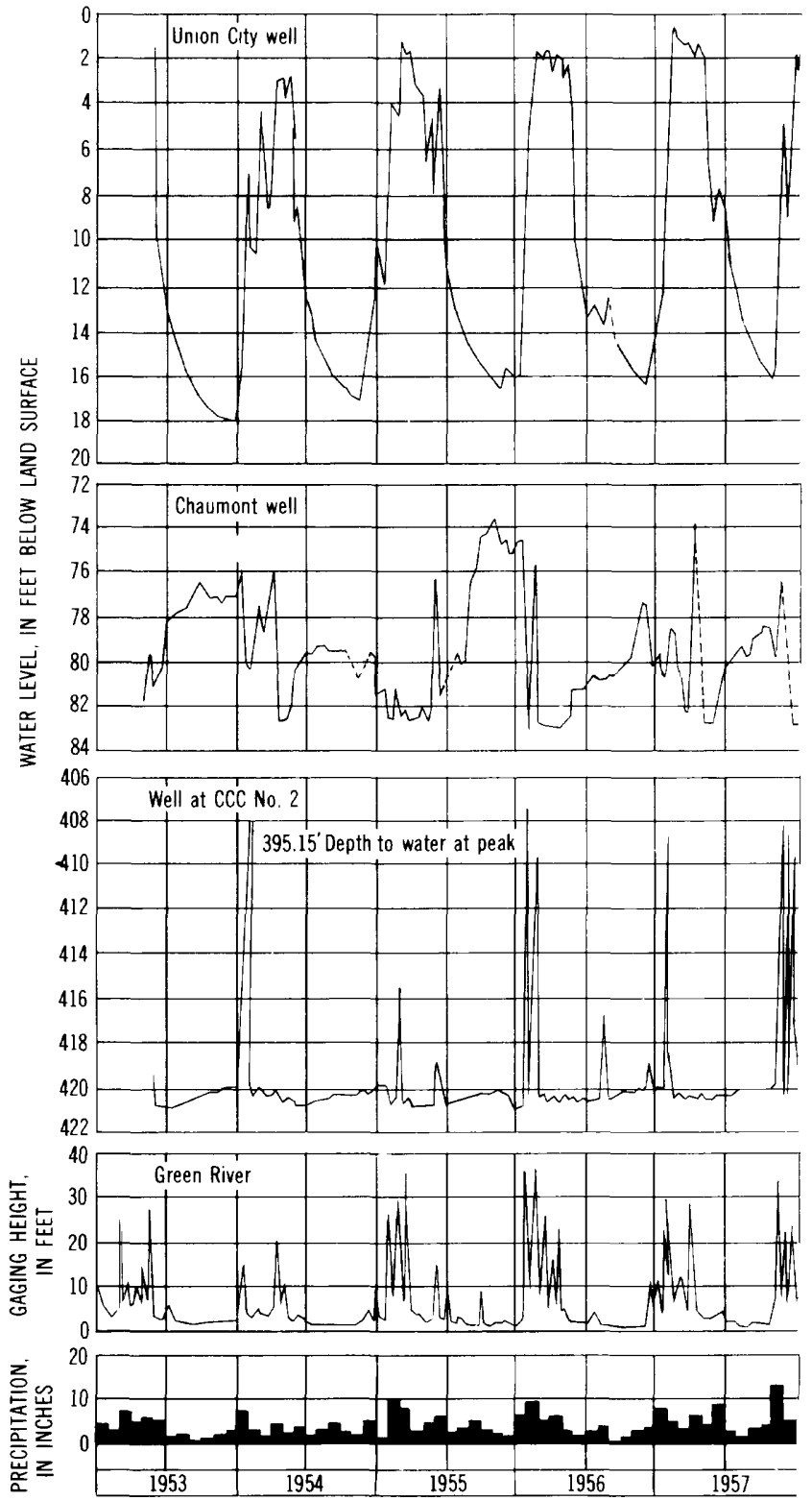

Figure 12.-Hydrographs of wells at CCC No. 2, Union City, Chammont, and Green River at Mammoth Cave Ferry ; and precipitation, Mammoth Cave area, 1953-57. 


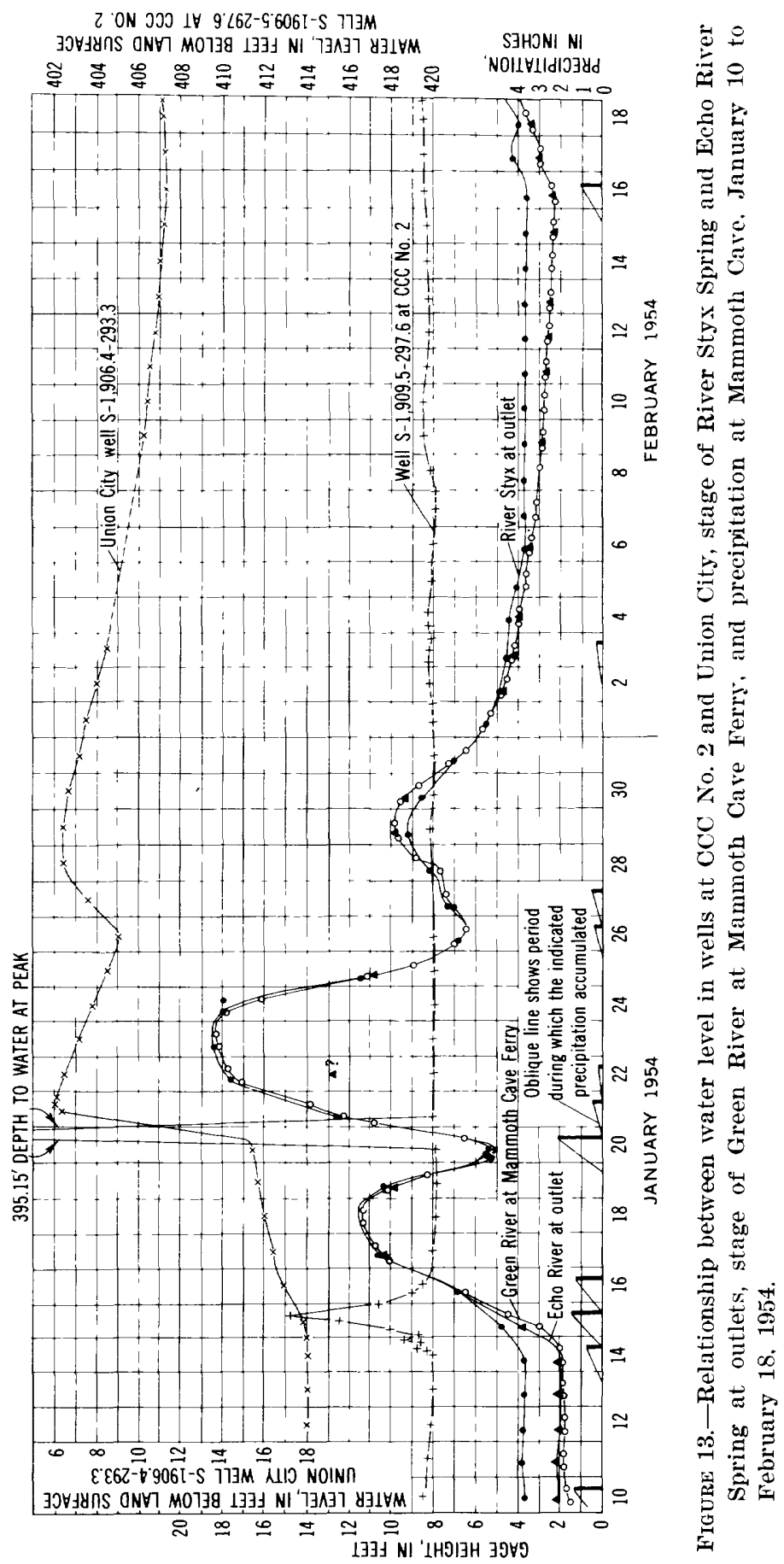



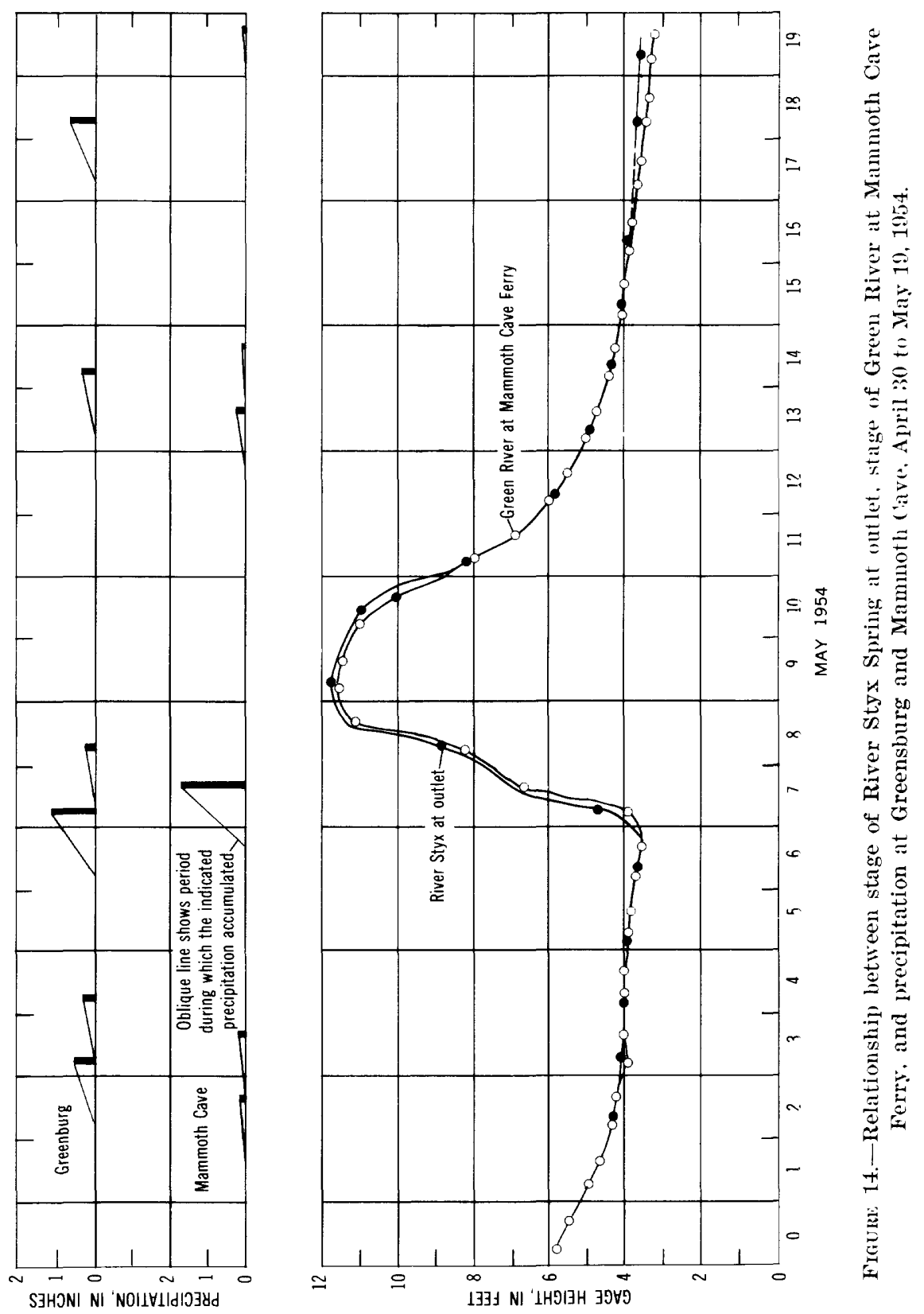


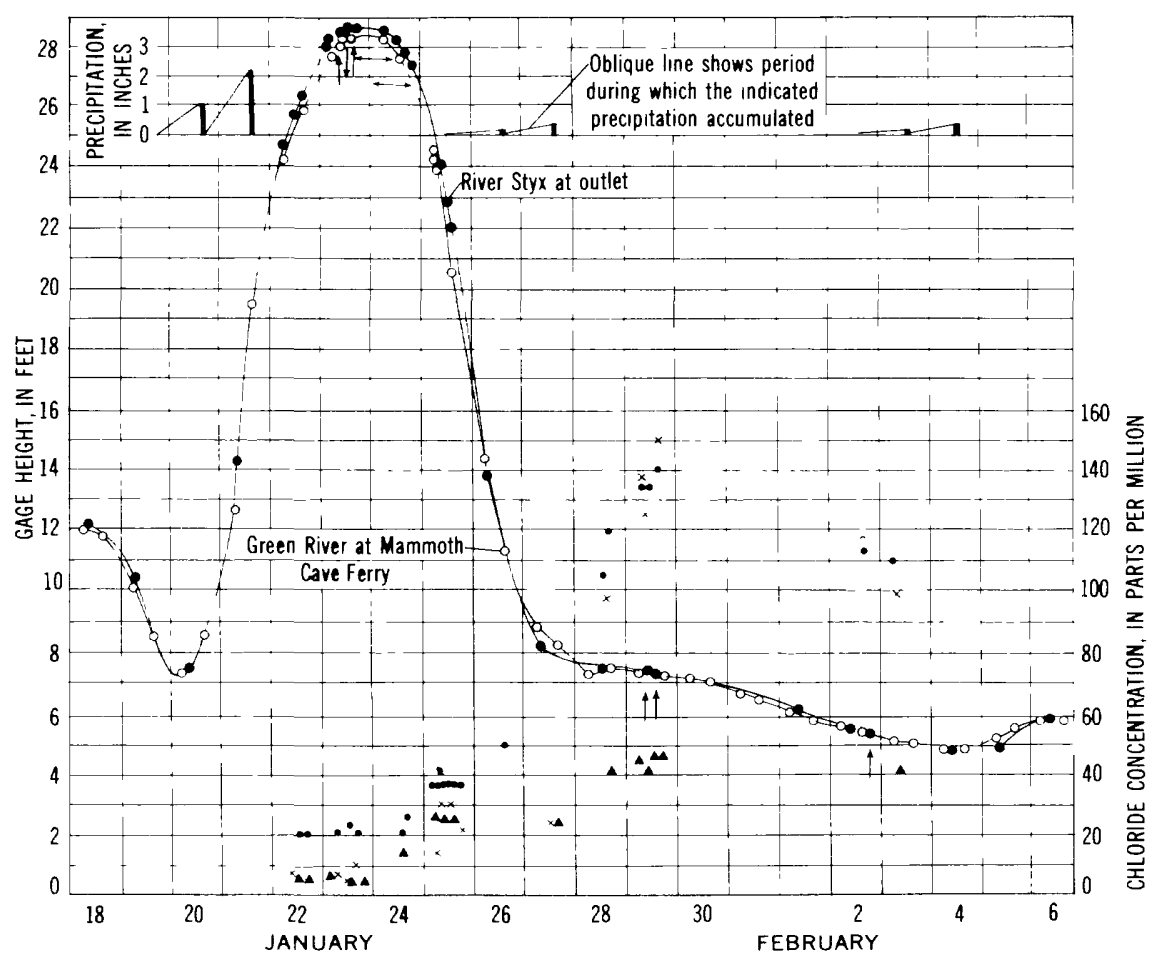

EXPLANATION

CHLORIDE CDNCENTRATION

River Styx at outlet

Echo River at outlet

Green River at Mammoth Cave Ferry
DIRECIIDN OF FLOW IN RIV:R STYX

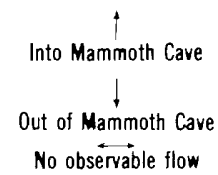

FIgtre 15.-Relationship between stage of River Styx Spring at outlet and stage of Green River at Mammoth Cave Ferry; relationship between chloride concentration and stage in Echo River, River Styx, and Green Piver: and precipitation at Mammoth Care, January 18 to February 6, 195?.

entire area of investigation, but it crops out only on the Pennyroyal plain. Exposures are rare because it is not resistant to weathering.

The St. Louis Limestone is the main water-bearing formation for that part of the area lying in the Pennyroyal plain south of the Dripping Springs escarpment. The upper part is especially soluble and cavernous. All the wells inventoried in the Pennyroyal plain probably derive their water from the St. Louis, and the wells having the largest yields are in the St. Louis. A well owned by the city of Horse Cave $(S-1,953.7-307.0)$ had a reported yield of $146 \mathrm{gpm}$ (gallons per minute), and a Cave City municipal well (S-1,939.1-293.8) had a reported yield of $300 \mathrm{gpm}$. In addition, there are large flows from several springs in the St. Louis. The flow of Hidden River Spring 


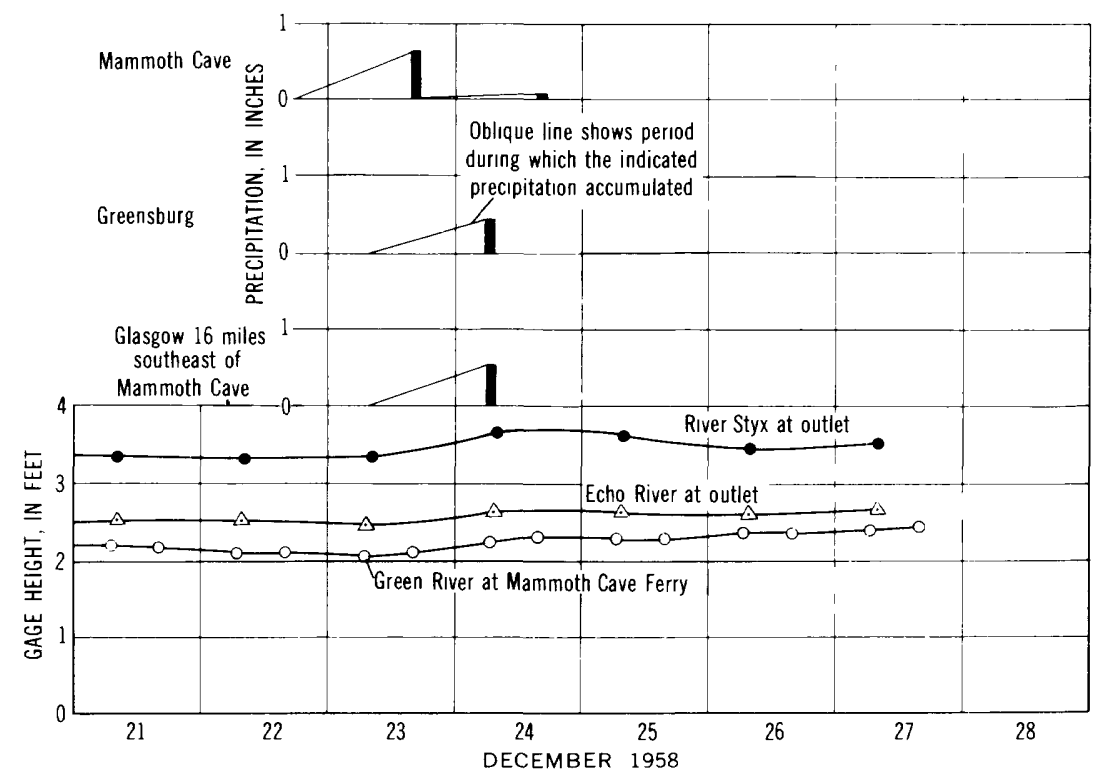

Figure 16.-Effect of precipitation at Mammoth Cave on stage of River Styx and Echo River Springs and of Green River at Mammoth Cave Ferry, December 21-27. 1958.

( $\mathbf{S}-1,954.6-307.9)$ in Hidden River Cave, near Horse Cave, was estimated to be $35,000 \mathrm{gpm}$ when risited, and a spring owned by the $\mathrm{L} \& \mathrm{~N}$ Railroad $(S-1,940 . \overline{-}-291.6)$ is reported to yield a minimum flow of 200 $\mathrm{gpm}$. In the southern part of the area, several streams flow northward on the upper part of the Warsaw and the lower part of the St. Louis for short distances, but all sink into underground channels before reaching the Dripping Springs escarpment. The network of solution channels in the St. Louis is so large that, even after heavy rains, all water drains underground in a few hours. There is little or no filtering action through these caverns, and the water carries a considerable amount of sediment: nearly all the wells in the area were reported to vield turbid water after heary rains. Hidden River Spring, which is in the St. Louis, discharges sereral thousand gallons of water per minute after heary rains (table 3 ) and at such times is turbid.

The chemical quality of samples of water obtained from the St. Louis Limestone is shown in table 4 .

\section{Ste. Genevieve Limestone}

The Ste. Genevieve Limestone is about 180 feet thick in this area. It consists of relatively pure oolitic finely crystalline limestone, occasional shale partings, and abundant chert. Crossbedding is common in the granular and oolitic beds. It ranges in color from nearly white or light gray to bluish gray and weathers to form a rusty-brown to 
TABLE 4.-Chemical analyses of water from wells, springs and the

[Results by U.S. Geol. Survey

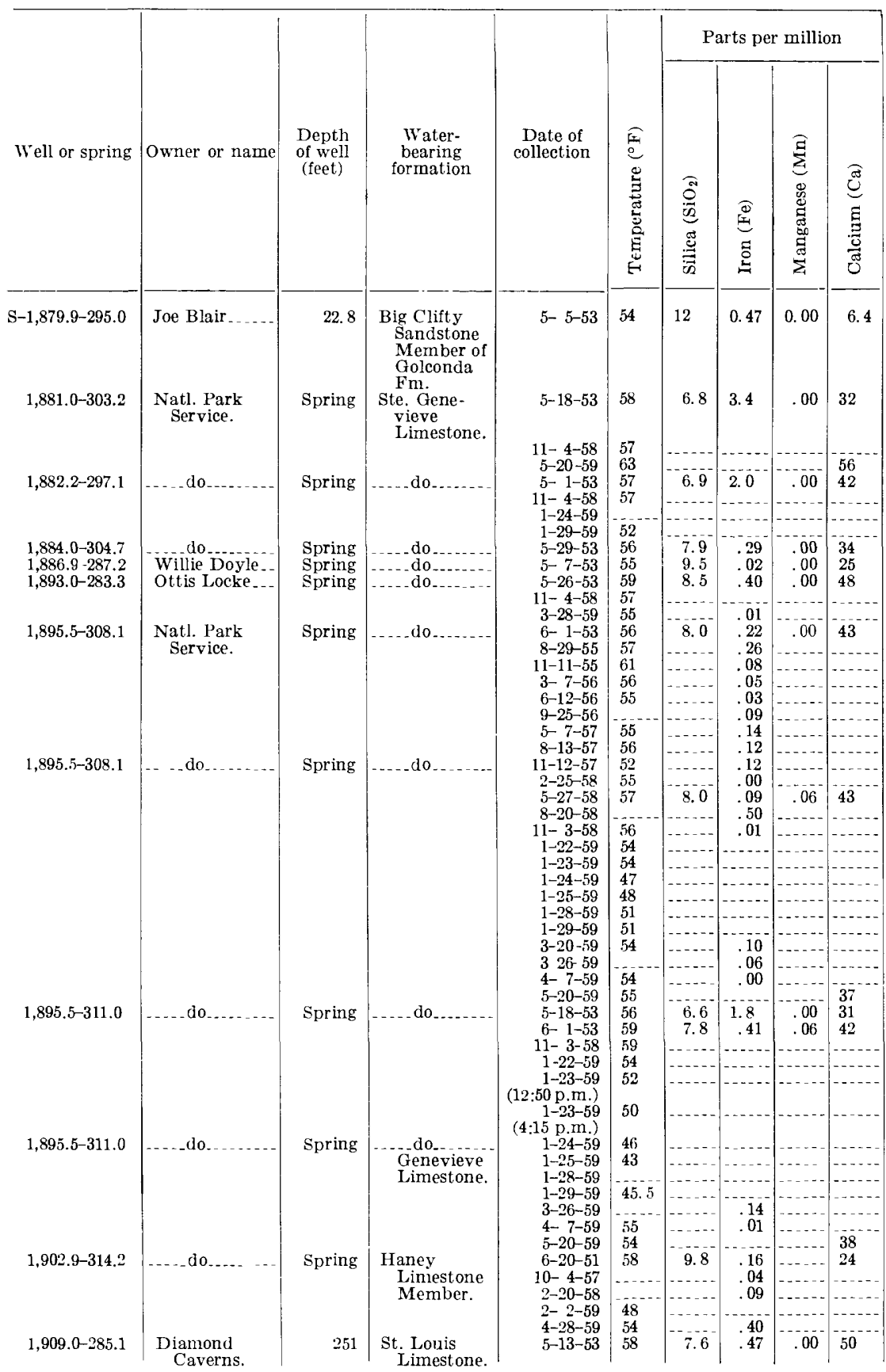

See footnotes at end of table. 
Green River in the vicinity of Mammoth Cave National Park

unless otherwise specified]

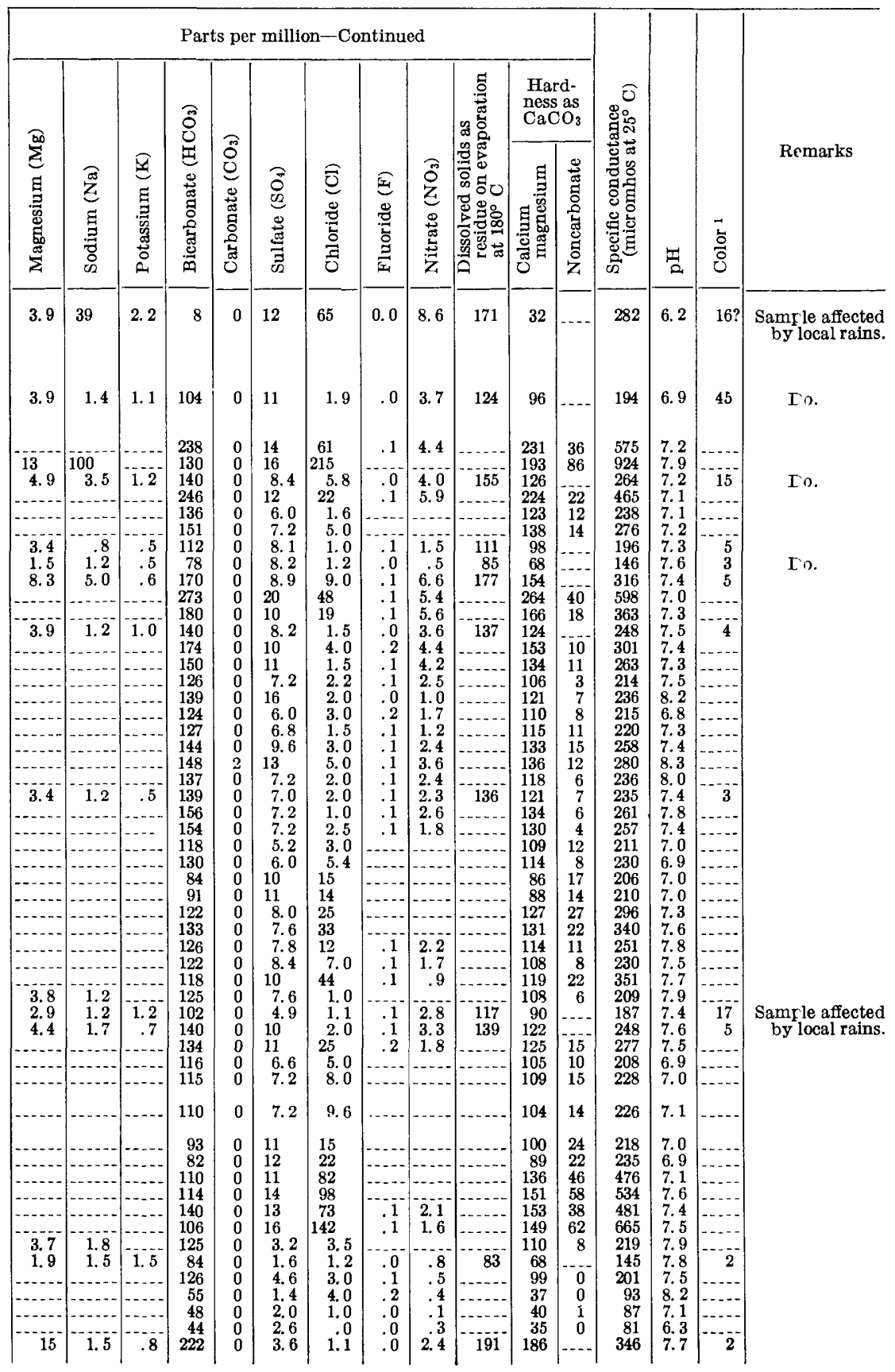


TABLE 4.--Chemical analyses of water from wells, springs, and the

\begin{tabular}{|c|c|c|c|c|c|c|c|c|c|}
\hline \multirow[b]{2}{*}{ Well or spring } & \multirow[b]{2}{*}{ Owner or name } & \multirow[b]{2}{*}{$\begin{array}{l}\text { Depth } \\
\text { of well } \\
\text { (feet) }\end{array}$} & \multirow[b]{2}{*}{$\begin{array}{c}\text { Water- } \\
\text { bearing } \\
\text { formation }\end{array}$} & \multirow[b]{2}{*}{$\begin{array}{l}\text { Date of } \\
\text { collection }\end{array}$} & \multirow[b]{2}{*}{ 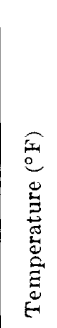 } & \multicolumn{4}{|c|}{ Parts per million } \\
\hline & & & & & & 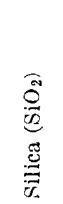 & 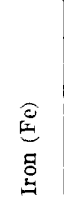 & 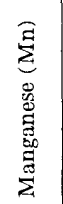 & 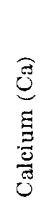 \\
\hline S-1,909.5-297.6 & $\begin{array}{l}\text { Natl. Park } \\
\text { Service. }\end{array}$ & 500 & $\begin{array}{l}\text { Ste. } \\
\text { Genevieve } \\
\text { Limestone. }\end{array}$ & $5-21-53$ & 58 & 9.5 & 0.68 & 0.02 & 42 \\
\hline $1,910.2-320.1$ & $\begin{array}{l}\text { Floyd Collins } \\
\text { Crystal }\end{array}$ & 422 & ... do......... & $\begin{array}{l}4-7-59 \\
5-12-53\end{array}$ & $\cdots$ & 9.0 & $\begin{array}{l}1.0 \\
.28\end{array}$ & .00 & 34 \\
\hline $1,913.4-276.9$ & $\begin{array}{l}\text { Cave. } \\
\text { W. L. } \\
\text { Gardner. }\end{array}$ & 225 & $\begin{array}{l}\text { St. Louis } \\
\text { Limestone. }\end{array}$ & $6-14-51$ & 59 & 9.5 & .20 & & 72 \\
\hline $1,939.2-293.8$ & Town of Cave & 240 & do & $\begin{array}{r}4-26-51 \\
10-8-57\end{array}$ & $\begin{array}{l}60 \\
59\end{array}$ & 12 & $\begin{array}{l}1.7 \\
.00\end{array}$ & $\ldots$ & 86 \\
\hline $1,940.7-291.6$ & $\begin{array}{l}\text { Louisville \& } \\
\text { Nashville } \\
\text { Railroad }\end{array}$ & Spring & ... do & $4-26-51$ & 58 & 9.1 & .17 & $\ldots$ & 50 \\
\hline $1,946.1-330.2$ & J. L. Garvin_. & Spring & $\begin{array}{l}\text { Ste. Gene- } \\
\text { vieve lime- }\end{array}$ & $\begin{array}{l}5-27-53 \\
11-5-58\end{array}$ & $\begin{array}{l}58 \\
52\end{array}$ & 8.9 & .41 & .00 & 51 \\
\hline $1,947.0-317.7$ & E. R. Pohl.... & 250 & $\begin{array}{l}\text { stone. } \\
\text { st. Louis } \\
\text { limestone. }\end{array}$ & $5-28-53$ & 58 & 8.4 & .40 & .00 & 41 \\
\hline \multirow{5}{*}{$\begin{array}{l}1,953.4-307.4 \\
1,953.7-307.0 \\
1,954.6-307.9\end{array}$} & $\left\{\begin{array}{l}\text { Horse Cave } \\
\text { Water Co. }\end{array}\right.$ & $\begin{array}{l}265 \\
315\end{array}$ & \} & $6-14-51$ & 56 & 9.9 & .27 & & 55 \\
\hline & Mrs. II. B. & Spring & ...... do... & $5-28-53$ & 58 & 9.1 & .24 & .00 & 51 \\
\hline & $\begin{array}{l}\text { Green River } \\
\text { at Mlunford- } \\
\text { ville. }\end{array}$ & River & & May $11-20$ & 62 & 12 & .03 & & 30 \\
\hline & & & & Sept. $\begin{array}{r}21-30 \\
1953\end{array}$ & & 8.8 & .04 & & 50 \\
\hline & & & & $\begin{array}{r}10-8-573 \\
5-19-59 ?\end{array}$ & 62 & & .10 & & 67 \\
\hline
\end{tabular}

I Color units based on platinum-colbalt scale of Hazen (1892, p. 427-428).

2 Collected at gaging station at bridge on U.S. Highway $31 \mathrm{~W}$.

3 Collected $3,000 \mathrm{ft}$ downstream from intake. 
Green River in the vicinity of Mammoth Cave National Park-Continued

\begin{tabular}{|c|c|c|c|c|c|c|c|c|c|c|c|c|c|c|c|}
\hline \multicolumn{12}{|c|}{ Parts per million-Continued } & \multirow{3}{*}{ 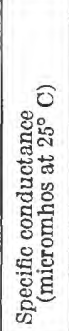 } & \multirow[b]{3}{*}{ 司 } & & \multirow[b]{3}{*}{ Remarks } \\
\hline \multirow[b]{2}{*}{ 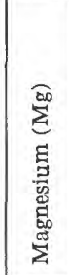 } & \multirow[b]{2}{*}{ 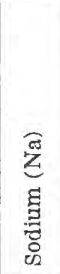 } & \multirow[b]{2}{*}{ 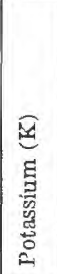 } & \multirow[b]{2}{*}{ 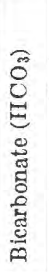 } & \multirow[b]{2}{*}{ 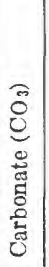 } & \multirow[b]{2}{*}{ 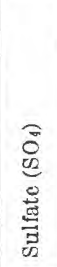 } & \multirow[b]{2}{*}{ 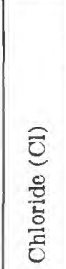 } & \multirow[b]{2}{*}{$\begin{array}{l}\text { 王 } \\
\text { 芯 } \\
\text { 总 }\end{array}$} & \multirow[b]{2}{*}{ 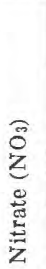 } & \multirow{2}{*}{ 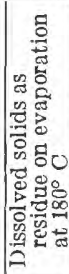 } & \multicolumn{2}{|c|}{$\begin{array}{l}\text { Hard- } \\
\text { ness as } \\
\mathrm{CaCO}_{3}\end{array}$} & & & & \\
\hline & & & & & & & & & & 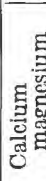 & 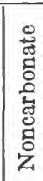 & & & 홍 & \\
\hline 22 & 8.0 & .9 & 168 & 0 & 54 & 12 & 1.3 & .0 & 256 & 196 & 28 & 407 & 7.3 & 13 & $\begin{array}{l}\text { Sample affected } \\
\text { by local rains } \\
\text { Phosphate } \\
0.02 \text {. }\end{array}$ \\
\hline 14 & 1.6 & .7 & $\begin{array}{l}156 \\
130\end{array}$ & $\begin{array}{l}0 \\
0\end{array}$ & $\begin{array}{l}44 \\
32\end{array}$ & $\begin{array}{l}2.0 \\
1.1\end{array}$ & $\begin{array}{r}1.4 \\
.6\end{array}$ & 2.2 & 179 & $\begin{array}{l}166 \\
140\end{array}$ & 38 & $\begin{array}{l}329 \\
277\end{array}$ & $\begin{array}{l}7.3 \\
7.7\end{array}$ & 3 & \\
\hline 16 & 1.9 & .9 & 194 & 0 & 85 & 3.0 & .4 & 2.9 & 295 & 246 & 86 & 464 & 7.7 & 1 & \\
\hline 27 & 8.1 & .4 & 232 & 0 & 139 & 8.0 & 1.0 & .1 & 421 & 326 & 135 & 614 & 7.0 & 1 & \\
\hline 6.8 & 1.2 & 1.1 & $\begin{array}{l}243 \\
182\end{array}$ & $\begin{array}{l}0 \\
0\end{array}$ & $\begin{array}{r}166 \\
4.4\end{array}$ & $\begin{array}{l}10 \\
1.9\end{array}$ & .1 & 9.7 & 167 & $\begin{array}{l}365 \\
154\end{array}$ & $\begin{array}{r}166 \\
4\end{array}$ & $\begin{array}{l}688 \\
295\end{array}$ & 7.2 & 0 & \\
\hline 6.8 & 4. 3 & .8 & 172 & $0_{0}^{0}$ & 12 & $74^{7.0}$ & .1 & $\begin{array}{l}8.3 \\
5.8\end{array}$ & 183 & $\begin{array}{l}156 \\
229\end{array}$ & 16 & $\begin{array}{l}325 \\
458\end{array}$ & 7.5 & 4 & \\
\hline 25 & .9 & .5 & 244 & 0 & 4. 4 & .8 & .4 & .6 & 190 & 204 & & 370 & 7.8 & 2 & \\
\hline 16 & 10 & 26 & 210 & 0 & 31 & 10 & 8 & 41 & 246 & 202 & 31 & 422 & 7.9 & 2 & \{Composite \\
\hline 8.3 & 2. 2 & .6 & 176 & 0 & 10 & 3.2 & .1 & 10 & 182 & 162 & & 329 & 7.4 & 4 & \\
\hline 5.3 & 2.9 & 1.2 & 105 & 0 & 12 & 2.5 & .0 & 3. 2 & 119 & 96 & $\ldots$ & 200 & 7.3 & 2 & $\begin{array}{l}\text { 10-day compos- } \\
\text { ite sample. } \\
353 \text { ppm sus- } \\
\text { pended mat- } \\
\text { ter. }\end{array}$ \\
\hline 8.8 & 8.1 & 1.4 & 174 & 0 & 16 & 12 & 1 & 1.5 & 194 & 161 & . & 337 & 7.6 & 1 & $\begin{array}{l}\text { 10-day compos- } \\
\text { ite sample. } \\
\text { ppm sus- } \\
\text { pended mat- } \\
\text { ter. }\end{array}$ \\
\hline 18 & 192 & & $\begin{array}{l}154 \\
116\end{array}$ & $\begin{array}{l}0 \\
0\end{array}$ & $\begin{array}{l}14 \\
19\end{array}$ & $\begin{array}{r}12 \\
380\end{array}$ & .1 & .9 & & $\begin{array}{l}140 \\
241\end{array}$ & 14 & $\begin{array}{r}303 \\
1,470\end{array}$ & $\begin{array}{l}8.2 \\
7.7\end{array}$ & & \\
\hline
\end{tabular}


bright-red clay. The oolites are abundant, and their presence is one of the means of distinguishing the formation from the underlying St. Louis Limestone. The Ste. Genevieve Limestone underlies the entire Mammoth Cave plateau in the area. It crops out on the sides of sinkholes on the plateau and along the edge of the Dripping Springs escarpment (fig. 17).

The Ste. Genevieve Limestone is the major aquifer underlying the Mammoth Cave plateau. The greater parts of Mammoth, Crystal, and Great Onyx Caves are developed in the Ste. Genevieve and in the

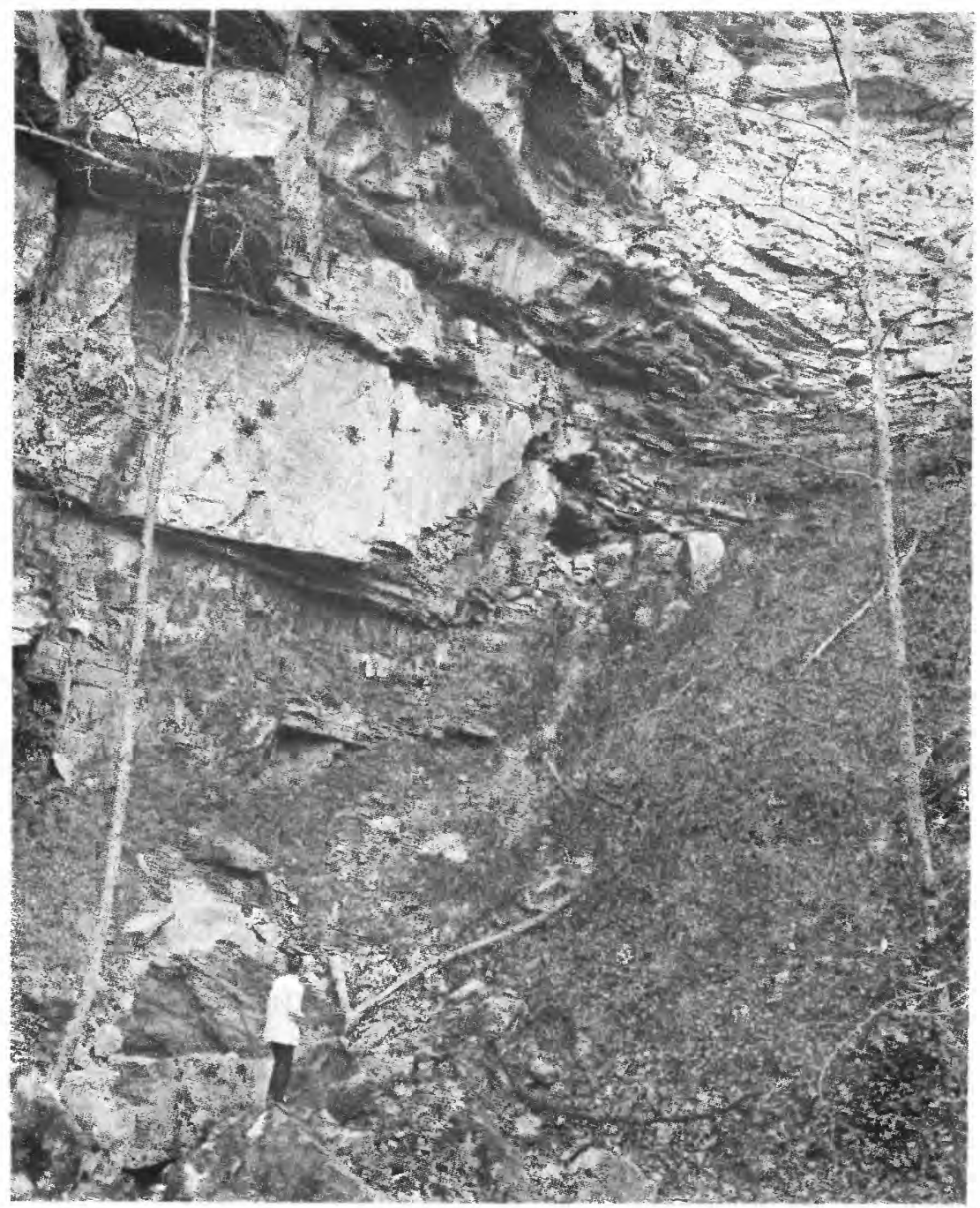

Figure 17.-Ste. Genevieve Limestone exposed on south side of Cedar Sink, Mammoth Cave National Park. Contact with the overlying Girkin Formation is at top of upper right corner. Photograph by W. Ray Scott. 
overlying Girkin Formation which is lithologically similar. The large cavernous openings and connected smaller openings serve as conduits for ground-water movement in the area. Six wells in this formation encountered fairly large quantities of water in solution openings. The water level in these openings fluctuates rapidly. During dry weather and after light summer rains, almost no change in the water level occurred; however, during a heavy spring rain, the water level rose nearly 20 feet in a day. These variations aro shown by the hydrograph of the well at CCC No. 2 (figs. 12,13).

The few wells on the Mammoth Cave plateau that are known to have been drilled into the Ste. Genevieve all yielded water, clthough the depth to water was generally 400 feet or more. It is probable that wells this deep also penetrate the top of the St. Louis (table 1). A short pumping test on Bransford well 1 (S-1,904.8-316.3) showed 18 feet of drawdown after pumping about 90 minutes at $10 \mathrm{gpm}$ (fig. 18). The log of this well is given on following page.

The owners of wells in the Ste. Genevieve reported that the water in these wells became turbid after heavy rains. Springs in the area that discharge from the same horizon also yielded turbid water after heavy rains. No samples of the sediment in the water were taken during the investigation.

The chemical quality of samples of water obtained from the Ste. Genevieve Limestone is shown in table 4.

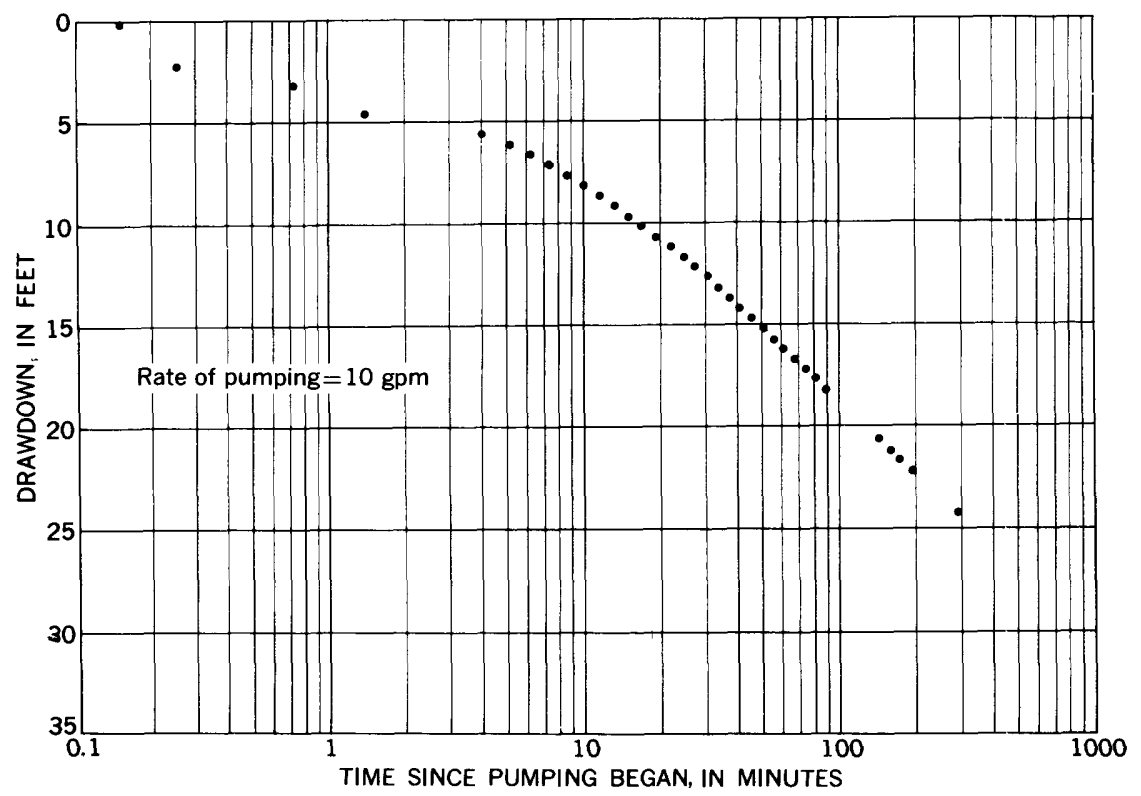

FIGURE 18.-Effect of pumping on water level in Bransford well 1. 
Sample log of Bransford well 1 drilled for National Park Service by Malcolm Dillingham, June 1953

[Samples examined and described by author]

Material

Dirt, composed of weathered sandstone, fine to coarse, and some fine to medium gravel; yellow-brown

Sandstone, fine to coarse, and fine gravel; yellow-brown.

Sandstone, fine to coarse, and fine gravel; light-gray ........

Sandstone, very finc to medium, light-gray.

Sandstone, very fine to medium, light-gray; limestone layer at $45 \mathrm{ft}$, medium-grained, gray.

Limest one, fine- to medium-grained, med um-gray

Limestone, fine- to medium-grained, oolitic, light-gray

Limestone, fine- to medium-grained, oolitic, light-gray; contains pyrite $\ldots \ldots \ldots \ldots \ldots$

Limestone, medium-grained, medium-gray _..............

Limestone, fine-grained, oolitic, medium-gray _.............

Limestone, fine-grained, medium-gray .

Limestone, fine-grained, oolitic, medium-gray

Limest one, fine-grained, medium-gray ...................... Thickness $\mid$ Depth (fe $3 \mathrm{t}) \quad$ (feet)

Limestone, fine-grained, very oolitic, medium-gray-

Limestone, fine-grained, medium-gray

Limestone, fine-grained, very oolitic, medium-gray

Limestone, fine-grained, medium-gray

Limestone, fine-grained, very oolitic, medium-gray

Limestone, fine-grained, dolomitic, medium-gray

Limestone, very fine-grained, oolitic, medium-gray. Oolites separate in sample.

Limestone, fine-grained, light-gray

Limestone, very fine grained to fine-grained, oolitic, mediumrer:y

Saud, menmolidated, very fine to medium, angular, clear, ilvil-siained, ycllow-tan

Sarid, unconsolidated, very fine to coarse, angular, clear, ironsiained, yellow-tan

Limestone, fine-grained, oolitic, medium-gray

Sand, very fine grained to fine-grained, angular, clear, ironstained

Limestone, finr-grained, light- to medium-gray

No samples.

Limestone, very fine grained to fine-grained, oolitic, light-gray

Sand, very fine to medium, angular to subangular, clear, iron-stained, ycllow-tan.

Water encountered in crevices at 60,317 , and $419 \mathrm{ft}$. 


\section{Girkin Formation}

\section{CHESTER SERIES}

In the report area the Girkin Formation is about 120 feet thick. Lithologically, it is very similar to the underlying Ste. Genevieve Limestone. It consists of light-gray limestone ranging in texture from coarse to fine crystalline. The lower part of the formation is characterized by oolitic zones and some shale beds. A shale layer is also present at the top of the formation in most places (E. R. Pohl, written commun., 1938). It does not contain significant quantities of chert, but it does contain spherical clusters of quartz crystals, which are characteristic of the Girkin residuum. The Girkin underlies the Mammoth Cave plateau and crops out in the sides of sinkholes and along the face of the Dripping Springs escarpment.

Ground water occurs in solution openings in the Girkin Formation. In some places this water is perched in small solution depressions within the formation, and the water in a given well may remain at about the same depth during most of the year. Many of these "perched" bodies have inlet and out let chamnels that transmit flow after precipitation, but they are dry at other times. In some wells the water supply may be only 1 or 2 gallons per day; in others, it may, with normal precipitation, be adequate for a domestic supply, although it likely will go dry during dry summers. Commonly, none of these perched water bodies are adequate for domestic supplies with pressure systems installed.

Some wells intercept water that is in a state of transition from one level to another. Water entering the upper part of the Girkin, generally from the overlying Big Clifty Sandstone Member of the Golconda flows downward toward the water table through solution channels of different sizes and shapes. Some of these openings are adequate to transmit large quantities of water, but others a re so small that the water must trickle or drip through. Clogging and opening of these chamnels through changes in the position of rock debris may rapidly affect the rate of flow. In addition, siphon tubes at different levels may intersect vertical or gently sloping channels at numerous points. Water levels then may fluctuate in the manner shown by the hydrograph of the Chaumont well (fig. 12). During the summer, when recharge is negligible, water levels rise gradually. The highest water levels are after heavy spring rains, and the lowest, immediately after the sharp rises. The more abrupt and the greater the rise, the greater the following decline. However, the water level will not fall below a certain limit regardless of the rapidity of water-level changes.

Drillers report that water in noticeable quantities may be found at numerous levels in the Girkin. In most wells, however, these waterbearing bodies are drilled through in order to reach the larger and more dependable supplies a vailable at the Green River level. Little data are 
available concerning yields from these perehed water bodies. Most domestic wells in the area obtain water from dug wells in the overlying Big Clifty, and most commercial wells have been drilled through to the Ste. Genevieve. The few domestic wells that may ol + ain water exclusively from the Girkin are reported adequate for use with a bailer, but they are generally inadequate for use with a pressure system. No samples of water were taken from wells obtaining water exclusively from the Girkin Formation.

\section{Big Clifty Sandstone Member of the Golconda Formation}

The Big Clifty Sandstone Member is about 60 feet thick where it caps the edge of the Dripping Springs escarpment. It consists of wellindurated medium-grained quartz sand. The surface is iron stained, and this color penetrates the rock to some degree. Crossbedding is common. 'The formation is resistant to weathering, and large talus blocks are common in the bottoms and along the sides of sinkholes. In some places these blocks are so large and apparently urdisturbed that they may be mistaken for rocks that are in place. The Big Clifty Sandstone Member caps a major part of the Mammoth Cave plateau. It crops out in many places on the plateau uplands and along the sides of many of the valleys; it also forms the cap of the Dripping Springs escarpment.

Most wells on the Mammoth Cave plateau obtain water from the Big Clifty. A perched body of water in the formation is supported by a relatively impermeable layer of shale at the top of the underlying Girkin Formation. The depth from the surface to the water table in this perched body of water ranges from about 2 to 20 feet. Yields of wells are not large, but dug wells $2-3$ feet in diameter yiold amounts of water that are adequate for domestic and stock use. The layer of shale is present locally in the underlying Girkin, but it is not continuous at the contact. Where it is absent, water from the Big Clifty drains out and recharges the underlying Girkin Formation and Ste. Genevieve Limestone. Water also drains near the perimeter of the area of outcrop where the water can discharge laterally from the Big Clifty on top of the Girkin. This drainage toward the perimeter of the formation is responsible for the numerous springs that give the escarpment its name.

The gradual loss of water from the Big Clifty Sandstone Member to the underlying formations is shown in the hydrograph of the Union City well (S-1, 906.4-293.3) (figs. 12, 13). When the water level in the formation is high, the hydrostatic head forsing the water out of the formation is high, and the water drains comparatively rapidly into the underlying formations. As the water level drops, the hydrostatic head decreases, and the rate of discharge from the Big Clifty into the underlying formations decreases proportionally. 
Although the quantity of water released to the lower formations is relatively insignificant during periods of heavy precipitation, it is probably a major source of water during extended dry periods. Analyses of water from the Big Clifty Sandstone Member are shown in table 4 .

\section{Haney Limestone Member of the Golconda Formation}

In the report area the Haney Limestone Member is about 49 feet thick. A shale is at the base of the Haney almost every where. Above this, the formation is relatively pure limestone, fine to coarse crystalline, and light gray. The limestone is very soluble in ground water and is honeycombed with solution channels, but the solution chennels in this limestone are much smaller in size than the large cares in the lower limestones. The channels, especially well developed in the upper part of the formation, continue down to the basal shale. The Haney Limest one Member crops out along the south edge of the Green River bluffs as far east as Turnhole Bend (Weller, 1927, p. 119) and caps several hills on the Mammoth Cave plateau.

No wells that obtained water from the Haney Limestone Member were inventoried. Three Springs (S-1, 902.9-314.2), Mammoth Cave National Park public water supply, was the only spring inventoried that yielded water from this formation; however, there are many seeps and springs on the basal shale in the formation (Weller, 1927, p. 121). Precipitation on the overlying Hardinsburg Sandstone percolates downward into the Haney where it enters an extensive network of solution channels. When the water reaches the basal shale in the Haney, it flows above the shale until it emerges as seeps and springs or is lost by erapotranspiration. After heary rains, Three Springs probably discharges as much as $1,000 \mathrm{gpm}$.

The chemical quality of the water is shown in the analysis of Inion City well in table 4.

\section{Hardinsburg Sandstone}

The Hardinsburg Sandstone has a maximum thickness in the area of about 30 feet. It is composed of medium-grained white sandstone beds ranging in thickness from 1 inch to 2 feet. They are considerably ripple marked, and the surface is stained dark brown by iron oxide. The upper and lower parts of the formation are shaly and in places relatively impervious to water.

The Hardinsburg crops out only on the tops of a few hills in the area and in a narrow strip along the south side of the Green River westward from the ricinity of Turnhole Bend (Weller, 1927, p. 125).

The water body in the formation is perched, being supported by the shale zones at the base. Depths to water are shallow, and wells in the formation are dug wells, of large diameter, used for domestic and stock supplies. Inasmuch as the Hardinsburg Sandstone and Big 
Clifty Sandstone Member of the Golconda Formation are lithologically similar, water in the Hardinsburg probably fluctuates in much the same way as it does in the Big Clifty. Vertical drainage from the Hardinsburg furnishes water to the underlying Haney Limestone Member.

\section{Glen Dean Limestone}

The Glen Dean Limestone has a maximum thickness of about 60 feet. In the central part of the national park area pre-Pennsylvanian erosion has removed the formation in many places. The Glen Dean is predominantly evenly bedded limestone, fine to con rse crystalline, and uniformly gray. A discontinuous layer of shale is at the base of the formation. The Glen Dean crops out on the top of Flint Ridge in two small areas, and is exposed west from Turnhole Bend on the top of the bluffs along the Green River.

Some springs are reported to issue from the base of the formation in the western part of the area where it attains its full thickness; however, in the eastern part of the area it is thin, discontinuous, and unimportant as an aquifer.

No wells that obtained water from the Glen Dean Limestone were inventoried.

\section{Leitchfield Formation}

The uppermost unit of the Chester Group is the Leitchfield Formation. In this area it consists predominantly of shale but contains some limestone and sandstone members. It has been eroded from most of the area south of the Green River in the nationil part, and its thickness here was not determined. Weller $(1927$, p. 140$)$ assigns a maximum thickness of 125 feet to the formation near the Grayson County line. It is progressively thimner southward and was remored by pre-Pennsylvanian erosion throughout most of the park.

The Leitchfield Formation is relatively impermesble. It probably yields only small quantities of water to wells in its areas of maximum thickness, and in the park area no wells are known to penetrate the formation.

\section{PENNSYLVANIAN SYSTEM}

\section{Caseyville Formation}

The Caseyville Formation of the Pennsylvanian System overlies the Leitchfield Formation in the national park. It consists of thickbedded sandstone and has a coarse pebble conglomerate at the base. Sandy shale is interbedded with the sandstone at some localities. The formation is thin and discontinuous on the south side of the Green River. It is, therefore, not important as a source of water or of recharge or discharge.

Rocks of Pennsylvanian age are the youngest consolidated rocks exposed in the Mammoth Cave area. 
CENOZOIC ERA

\section{QUATERNARY SYSTEM}

\section{PLEISTOCENE AND RECENT DEPOSITS}

In the Green River valley, deposits of sand and gravel of Pleistocene and Recent ages have a maximum reported thickness of 80 feet (unpub. rept. on Mining City Dam Site, U.S. Corps of Engineers). Weller (1927, p. 170) reports river terraces 6-8 feet above the level of the present flood plain and gravel in Warren County to the west that is 60 feet above the present river level. According to Weller (1927, p. 171)

Some allurial material is present along the courses of all of the small streams in Edmondson County, but flood plains or valley flats are absent except along Green and Nolin Rivers and Bear and Reedy Creeks where typical flood plains are developed. Due to the steep $V$-shape of the valler they are in most places quite narrow and are not uncommonls present upon only one side of the stream. These deposits are composed of silts and muds with the admixture of a considerable amount of sand. In contrast to this, the alluvium of the smaller tributaries is more sandy and contains both angular and rounded pebbles derived from the immediatels adiacent formations.

In addition, there are extensive deposits of sand and silt and some gravel in the cave passageways. The maximum thickness of this fill is not known, but thicknesses of more than 30 feet have been reported (E. R. Pohl, written commun., 1938). In some places the material is predominantly sand derived from the overlying Big Clifty Sandstone Member. In other places there are considerable thicknesses of gravel derived from weathering of the Caseyville Formation of the Pennsylvanian System and from the high-level gravel deposits of Pleistocene age. The predominating deposits are composed of silt and clay that was left as insoluble residue from the solution of limestone. Most of the deposits have been reworked many times, and in some places they show evidence of deposition from rapidly moving water. During floods much of the material in the lower passages is reworked and redeposited; thus, some of the material is residual, some is from the Green River, and some is derived from the surfaces of the Mammoth Cave plateau and the Pennyroyal plain.

The deposits of Pleistocene and Recent ages are an important key to understanding the physiographic history of the region. Terrace deposits on the streams indicate different stream levels during Pleistocene time, and accurate dating of these and of the silt deposits in the care may lead to further refinement of the knowledge of physiog aphic processes during Pleistocene time.

The deposits of Pleistocene and Recent ages in the smaller tril 'itary streams cover small areas, and are so thin as to be relatively unimportant as a source of water. The deposits in the flood plains of the Green and Nolin Rivers, are relatively thick, but they are composed chiefly of fine-grained material that will yield little or no water to wells. 
However, it is possible that lenses of sand and gravel locally may yield moderate to large amounts of water. A well in alluvium near the Green River at Brownsville, about 5 miles downstream from the Mammoth Cave area, is reported to yield $77 \mathrm{gpm}$; this witer is used for the public supply.

The greatest hydrologic significance of the Pleistocene and Recent deposits is the control that they have on the movement and storage of water in the areal. During periods of flood, large quantities of water are stored in the allurial deposits along the banks of the streams and in the silt and sand deposits in the caves. This water is discharged slowly over many weeks and helps to maintain a more constant discharge of ground water. In addition, silt barriers in the solution channels in the cares impede the morement of water through the carerns and particularly impede the flow through minute crevices and fractures in the limestone. Some of the silt barriers in the large carerns of the cave are tens of feet across. These barriers form ponds containing large quantities of water during the summer and fall, when recharge into the cave passageways is relatively small.

\section{GENERAL HYDROLOGIC CONDITIONS}

The average annual r'unoff in the Green River basin above the gage at the Mammoth Care Ferry is about 19 inches; the arerage annual precipitation is 48 inches. The average annual loss by eraporation and transpiration is about 29 inches. Drainage divides in a cavernous limestone area may not be coincident with topographic divides, and, therefore, the above figures, based on topographic drinage divides, may be in error. In general, within the park area, water north of the Green River flows in surface streams, and water south of the Green River follows subsurface drainage patterns.

South of the river, ground water moves from the Pennyroyal plain northwestward to the Green River. Streams flow in tl is direction to within 11/2 miles of the Dripping Springs escarpment, then disappear under the surface and flow from that point to the Green River as subsurface streams. A piezometric surface, continuous with the level of the Green River and intersecting the surface of such underground streams as the Echo River and Rirer Styx, probably exists throughout the area investigated. The surface of the water observert in the deeper sinks, such as Mill Hole and Cedar' Sink, may be continuous with this piezometric surface. Below this surface all openings in the rocks are saturated. Because soluble limestone underlies this surface throughout the area, the openings are connected solution carities through which considerable ground water can move at relatively high relocities.

Recharge to the lower ground-water body probably comes from several sources: (1) the sinking streams that flow towards the Dripping Springs escarpment on the surface of the Pemyroyal plain and disappear into sinkholes before they reach the escarpment; $(2)$ local 
precipitation on the Mammoth ('are plateau, which goes rapidly underground through sinkholes or percolates slowly downward through the overlying formations; and (3) recharge from the Green River, especially in time of flood, through solution carities, such as River Styx, that are connected to the river.

Lying above this main ground-water body are several perched water bodies. Each of these is recharged by local precipitation in outcrop areas and by downward percolation from overlying formations. In the sandstone formations the water bodies are nearly continuous through the formation; in the limestone formations they are probably discontinuous.

Discharge from the lower ground-water body is generally through springs that discharge into the Green River. There may be many springs in the bottom of the Green River that discharge large quantities of water. Six springs that discharge near the level of the Green River probably are the main source of discharge from the area. From southwest to northeast these springs are: Turnhole $(\mathrm{S}-1,881.0-303.2)$, Sand Cave (S-1,884.1)-304.7), Echo River (S-1,895.5-308.1) (fiç. 19),

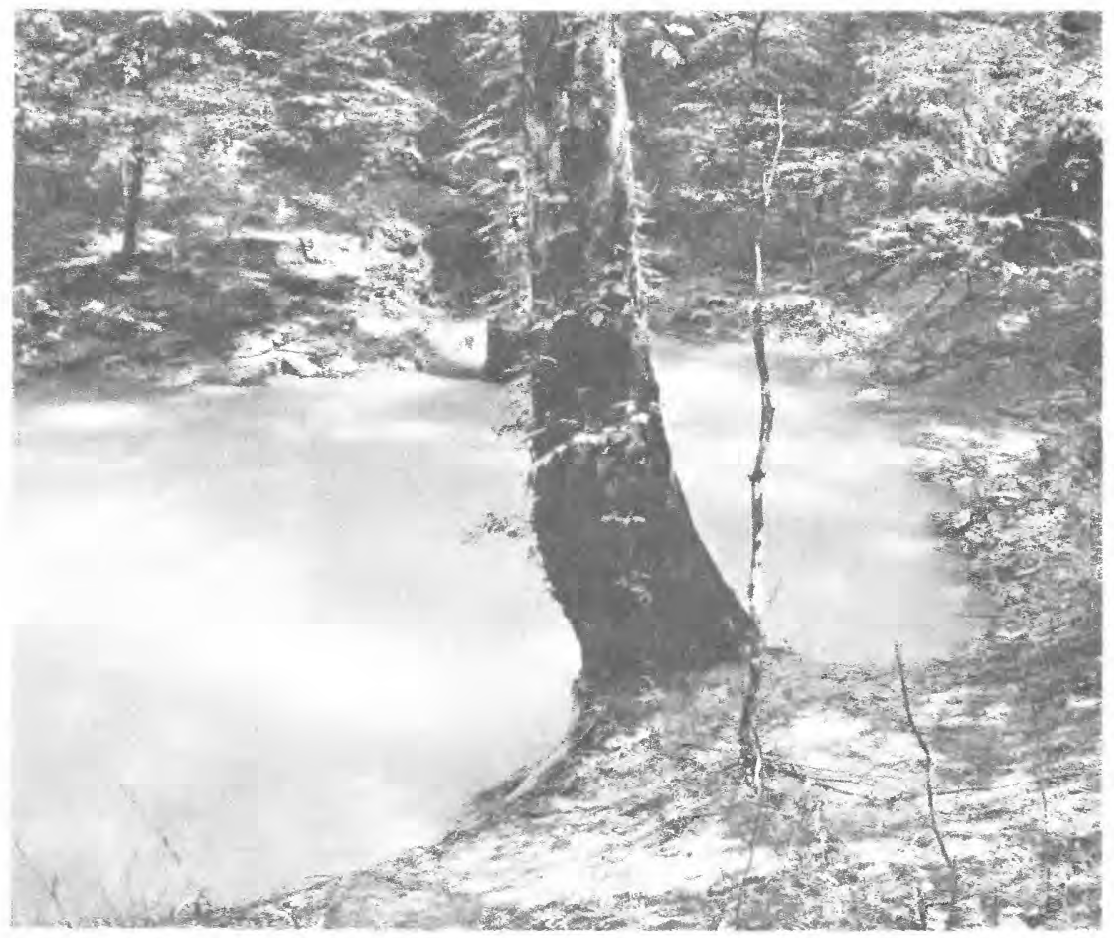

Figure 19.-Outlet of Echo River. The spring discharge. generally more than $100 \mathrm{~g} p \mathrm{~m}$. appears small because the flow issues from a cavern abont 3 feet below the water surface. Increased discharge following heavy rain causes rolling boils. I'hotograph by W. Ray Scott. 
River Styx (S-1,895.5-311.0) (fig. 20), Pike (S-1,911.0-320.9), and Garvin $(\mathrm{S}-1,9+6.1-3330.2)$.

The exact area that these springs drain is not known. Cedar Spring Valley, Woolsey Valley, and most of the streams on the western part of the Pennyroyal plain may discharge through the Turnlole and, to at lesser extent, through sand (ave Spring. Probably most of the water from Dovel Valley, some of Houchens Villey, and Bruce Hollow, ats well ats some of the precipitation on Mammoth Cave Ridge, discharges from the Echo River and River Styx. 'These streams have heen observed underground in Manmoth ('are and the New Discovery, which underlies. Jim Iee Ridge. Dye tests made by the Inouisville Gas \& Electric Co. in 19.24 and 1925 provide additional information on underground flow. The tests are described by R. B. Anderson (umpub. rept., 19.5). During the tests, dye was int rodnced at several points to determine the direction of undergromed drainage. Dye introduced at Three springs ( 5 on fig. 10), the present (1959) source of water for Mammoth ('ave Hotel and the national park installations,

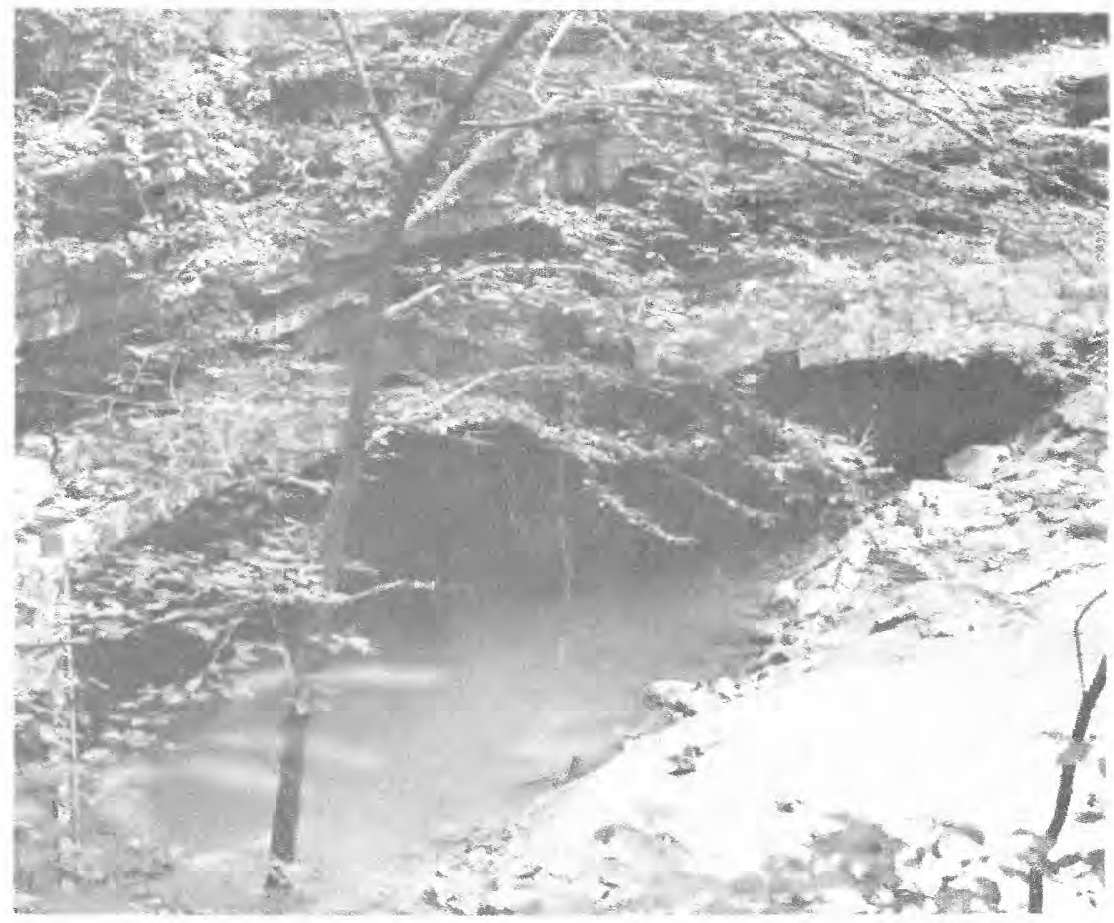

Fratre: 20.-Cutlet of River Styx. Staff gase shown at lower left. Exposed

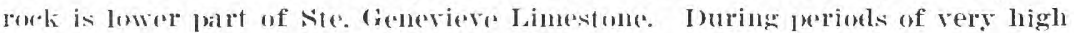
tlow the cavern is eompletely filled with water. High stage in the Green River combined with a low stage in River Styx anuses a reversal in flow from the Green River into Mammon cave. I'resmmably. this water discharges downstram al Eoho River spring or possibly at Turuhohe Bent. I'hotograph by Ir. Ray soott. 
discharged from the Echo River 15 hours after it was introduced. According to the report, the dye was "pushed through rapidly by rain. River Styx [was] flowing in [backward from the Green River into Mammoth Cave] at time dye came out; otherwise it would, no doubt, have come out there."

Water flowing under Flint Ridge and probably under part of Hamilton and Houchens Valleys discharges from Pike Spring. The solution channels underlying Flint Ridge, including large water-flled channels that connect with Pike Spring, are being mapped by the Care Research Foundation. The extent of this system is as yet not known, but more than 35 miles of passage have been mapped. 'The Louisville Gas \& Electric Co. dye tests provide some information on the areas of recharge contributing to some of the springs. The approximate area included in these tests, the locations of the points where dye was introduced, and the discharge points are shown in figure 10. Dye introduced at Bransford Spring $(t)$ discharged from Pike Spring in 48 hours; dye introduced in the river in Colossal Care (1) discharged from Pike Spring in 192 hours; dye introduced in Upper Branch, Colossal Cave (5), discharged from Pike Spring in 168 hours; dye introduced in Vaughns Dome ( 7 ) and Colossal Dome (8) of Colossal Cave discharged from Pike Spring in 60 and 45 hours, respectively. The lowest altitude at which dye was introduced was 640 feet.

Sand Cave and Garvin Springs and numerous small springs along the south side of the Green River have not been examined in as much detail. Except that many of the springs discharge tremendous quantities of water, almost nothing is known about them. Some may be outlets for part of the water that flows from the Green River into River Styx ; others are almost certainly outlets for drainage from large areas of the Pennyroyal plain and Mammoth Cave plateau.

\section{FLUCTUATIONS OF WATER LEVELS AND UNDERGROUND-FLOW RELATIONSHIPS}

Fluctuations of water levels under the Mammoth Cave plateau were determined by measuring depths to water in selected wells and reading gage heights of water levels in streams inside the cave. Continuous recording gages were installed on Union ('ity, ('haumont, and CCC No. 2 wells during May 1953. Continuous records of water-level fluctuations in the wells have been kept since that time. Staff gages were installed at River Hall (sometimes called River Styx) and Roaring River inside the cave and at the outlets of River Styx and Echo River in May 1953 by the surface Water Branch, C.S. Geological Survey. (See fig. 21.)

The two staff gages inside the cave were read once daily by the National Park Service personnel from July 1953 to January 1954. Otherwise, only an occasional reading was made. However, a record- 
ing bubble gage was installed on February 20, 1958, to obtain a continuous stage record of Echo River in the cave. The recording point (gage orifice) is located in Dead Sea, and above a stage of about 20 feet the sea is known to be connected with the Echo River through River Styx. No discharge measurements are availab'e at gages in the cave.

Gage-height readings of the two outlet gages, River Styx and Echo kiver, are generally complete since installation. The Ground Water Branch installed a recording gage on Echo River outlet in September 1959 and on River Styx outlet in October 1959. Discharge measurements made by both branches are available in most years beginning in 1953. Those made by the Surface Water Branch are published as miscellaneous measurements in the annual water-supply paper. No records of stage or daily discharge of the two outlets is published.

Twice-daily readings of the staff gage on the Green River at Mammoth Cave Ferry, about 400 feet downstream from the outlet of the Echo River and about 2,800 feet downstream from the outlet of River Styx (fig. 21) were made available by the Surface Water Branch. This stage record is complete since July 1938 . Discharge records were published during the period July 1938 to September 1050. A recorder of the bubble-gage type was installed at the ferry on January 28,1960 . Readings of the staff gage at the ferry since 1950, and once-daily readings of the two outlet gages since 1953, were made by tr o National Park Service personnel. The gradient of the Green River from a point opposite River Styx outlet to the gage at the ferry generally is about 0.2 foot. The gradient from the Eoho River outlet is about 0.01 foot. All gage readings have been adjusted to the same zero datum, 420.22 feet above sea level.

Fluctuation of water levels in the wells, the stage of the Green River, and precipitation for the period 1953-57 are shown in figure 12. The diagrammatic section through the Dripping Springs escarpment (fig. 11) shows the relationship of the several water bcdies, the Green River, and the wells.

The hydrograph of Union City well (fig. 12) shows fluctuations of water level in a well in the Big Clifty Sandstone Member. The graph shows that rapid recharge occurs during the winter and that the rate of discharge decreases gradually from about May to November. Rapid recharge starts when the deficiency of moisture in the soil has been replaced and continues until the growing season begins in May.

Discharge from the Big Clifty is predominantly through interformational leakage, lateral migration of water to springs on the perimeter of the area, and evapotranspiration. Probably the greatest quantity of water is discharged through evapotrarspiration. The water table is relatively close to the surface, especially during the spring, and conditions are ideal for large losses through evapotran- 


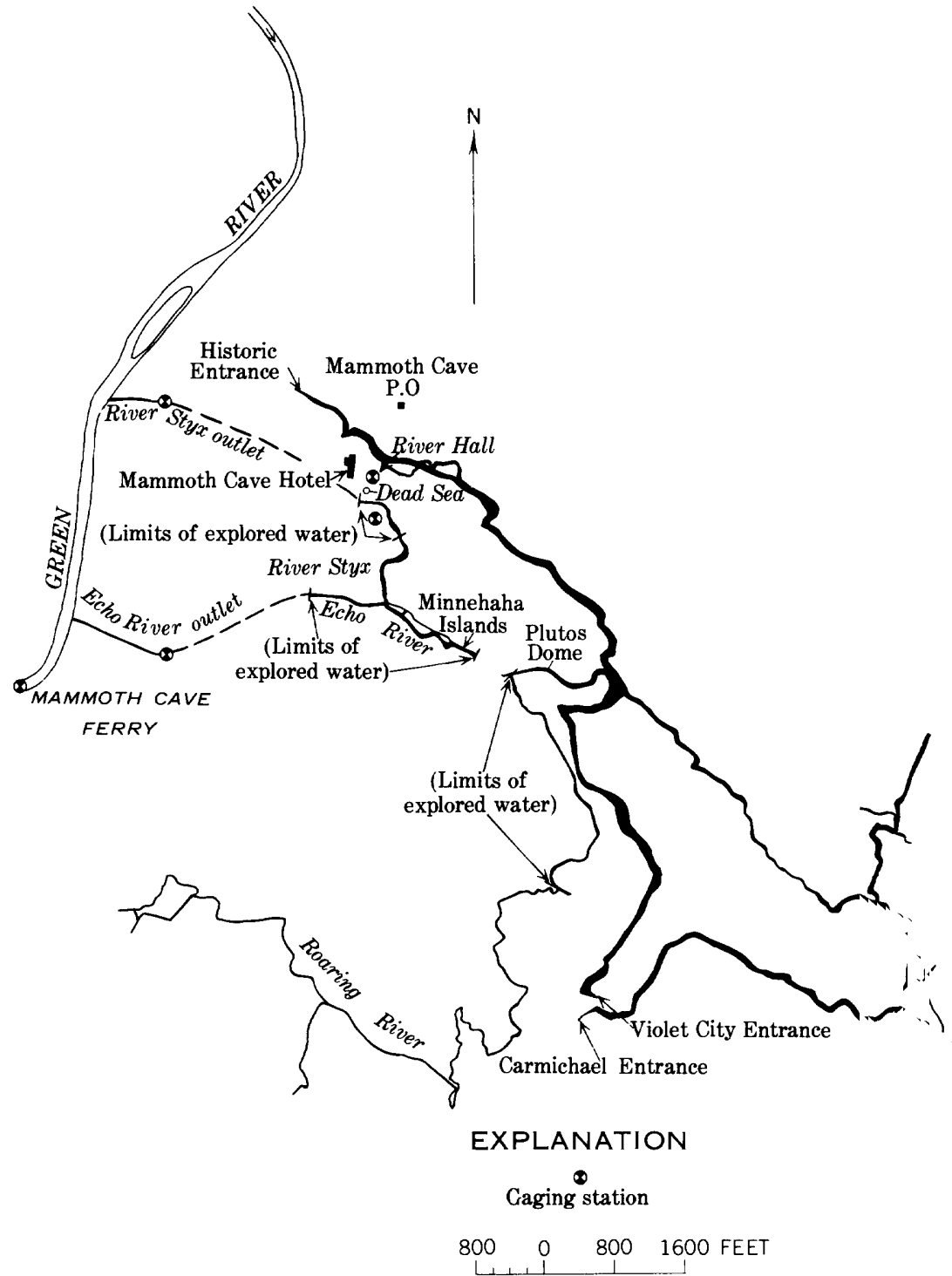

FIgURE 21.-Cave passages, major subsurface streams, and gaging stations in the Mammoth Cave area.

spiration. During the fall, when the depth to water is greater, the quantity of water discharged by evapotranspiration is much less.

Where shale is not present at the top of the Girkin Formation, some water may percolate downward from the Big Clifty into the Girkin. In those areas where the shale is continuous, the water moves laterally through the Big Clifty and discharges as springs and seeps or is lost by evapotranspiration at the edge of the escarpment and along the sides of the narrow, elongated ridges that are capped by the Big Clifty. 
These springs give the Dripping Springs escarpment its name and constitute a major source of discharge from the formation. Much of the water discharged by these springs flows back into the ground through fractures and solution cavities in the Girkin.

The hydrograph of the Chaumont well (fig. 12) in the Girkin shows the effects of this continuous recharge during the dry period of the year. The highest water levels are recorded during tlo winter just as in the Big Clifty Sandstore Member; however, the high peaks are as quickly followed by extreme lows because of the siphon action in solution openings intersecting the well. During the periods of little recharge, when the water level in the well in the Big Clifty declines at a nearly constant rate for extended periods of time, the water level in the well in the Girkin gradually rises. This is probably caused by recharge from water seeping down from the overlying Big Clifty, either from the edge of the escarpment or from areas where the shale in the Girkin is absent.

Wells drilled in this area may intercept five or more "streams" of water in the Girkin. Each of these is connected to the water in the Big Clifty Sandstone Member above and the water in the Ste. Genevieve Limestone below by innumerable conduits of different sizes, ranging from hairline cracks to large caverns similar to those that constitute Mammoth Cave. Many of these passageway: are plugged with silt; some are complicated networks of passageways that create siphons at different levels, overflow releases, constrictions, and vertical drains. The effect of this network of passageways is to cause a nearly infinite number of patterns of fluctuations of water levels in wells that penetrate one or more of these passageways. The behavior of the water level in a well is affected by the height of the water tablo, intensity of rainfall, location of rainfall, quantity of water recharging from the overlying Big Clifty Sandstone Member, and the quantity discharging horizontally as springs and vertically into the underlying Ste. Genevieve Limestone. The hydrograph of the Chaumont well, therefore, is not considered to be typical of the water-level fluctuations in the Girkin; rather, it is an example of only one type of fluctuation.

The hydrograph of the well at CCC No. 2 shows fluct rations of the water surface that are more or less contiguous with the Green River. The well is about 500 feet deep, and the water level is in the horizon of the Ste. Genevieve Limestone. The water level fluctuates rapidly-as much as 25 feet in less than a day. Some of the rises are followed by a siphon action that lowers the water level in the well below that maintained before the rise. In general, the rises correspond to similar rises in the Green River, but they precede them and are much more rapid. The hydrograph indicates that the well at CCC No. 2 intersects an opening of moderate size that is connected by a siphon tube to one of the larger passageways in Mammoth Cave. Below the 420- 
foot level this passageway probably acts as a lake that is emptied by a siphon and then is gradually reflled over a period of several weeks by water filtering downward from the overlying Girkin Formation.

The relationship between the water level in wells, stage of the springs, Echo River and River Styx, stage of the Green River, and precipitation at Mammoth Cave are shown in figure 13. In considering this and subsequent illustrations, it should be kept in mind that the normal gradient of the Green River is about 0.2 foot from the point opposite River Styx to the Mammoth Cave Ferry. Precipitation on January 10, 1954, apparently was enough to saturate the soil. A slight rise occurred in River Styx and the Echo and Green Rivers, sut the CCC No. 2 and Union City wells were not affected; in fact, the water level in the well at CCC No. 2 declined at a fairly uniform rate from January 10 to 13,1954 . Heavy precipitation on January 14-16 caused a sharp rise in all water levels. The precipitation was general throughout the State and caused a rise in the Green River that reached a peak on January 18. River Styx rose before the Green or Echo Rivers and was at a higher stage than either of them until January 16 ; but shortly after that, the surge of water from the cave area iecane relatively smaller, and the rapid rise in the Green River apparently created a reversal in gradients, so that the Green River flowed into River Styx and into the various cave passages. The Echo River rose rapidly from the effects of local precipitation, but the stage was nearly identical with that of the Green River by January 16, 1954, and remained so throughout this rise.

During the night of January 19-20, 1954, heavy precipitation becan again and continued through January 22. The effect on water levels in the well at CCC No. 2 was almost instantaneous. The water level in the well rose 24 feet in slightly more than 6 hours and declined the same amount in about 12 hours. The hydrograph of the water level in the well at CCC No. 2 shows clearly the type of fluctuation common in many places in the limestone areas of Kentucky. During low-flow veriods the water in subsurface conduits behaves in much the same manner as a stream. Moderate amounts of precipitation on January $14-16$, as shown in the first part of the graph, cause a rise that plots to a shape roughly similar to a rise on a small river; however, wh on precipitation is large in quantity, and particularly when it is intense in a small area, these subsurface streams in conduits can be compared with water flowing through a large tube having several vertical tubes of different sizes connected to the large tube. When large quantities of water are forced into the large tube, the water in the smaller tubes rises suddenly, the rate of rise depending on the diameter of the tube, the number and diameter of other tubes connected to the large tube, and the pressure under which water is being forced into the large tube. Such a hydraulic system will result in rapid rises in water level in some 
of the vertical tubes if water is introduced into one end of the large tube under considerable pressure; the decline is equally rapid when the pressure is reduced.

Just such a system is underneath Mammoth Cave plateau. Several large conduits trend generally northwestward toward the river. Adjoining these are numerous cross conduits and vertic, 1 shafts of many diameters and shapes. Although conduits may be of large size, restrictions may prevent a rapid flow of water. Some of the restrictions may be so great that several days, weeks, or even months are required for the water from heavy rains to seep out into main channels.

The different hydrologic characteristics of cavernous limestone aquifers and sandstone aquifers are strikingly shown by comparing the graph of the well at CCC No. 2 with the Union City well (fig. 13). Union City well shows typical water-table fluctuations in a sandstone bed of fairly uniform porosity and permability; the well at CCC No. 2 shows water-level fluctuations that illustrate the behavior of water in an extremely cavernous limestone formation. The precipitation on January 19-20 caused a rise of about 9 feet in the Union City well. The well continued to rise slowly until the afternoon of January 21 and then began to decline. The rate of decline was about one-twentieth the maximum rate of rise.

The precipitation of January 19-22, 1954, caused a sharp rise in water levels in the Green and Echo Rivers and River Styx. For about 20 hours, the stage of all three rivers rose at about the same rate, and during most of this time the Green River probably flowed into River Styx. About 6:00 a.m., January 21, the surge of water from precipitation on the Pennyroyal plain and Mammoth Cave plateau reached the outlet of River Styx, and discharge was intermittent until January 25. A similar rise probably occurred at the Echo $\mathrm{K}$ : ver, but as there was no gage above 16 feet, no record of stage could be obtained. On January 26-27, 1954, almost 1 more inch of rain fell. The rise in stage of the various water bodies was similar to the previous rise, except that the volume of water flowing from Mammoth Cave into River Styx was not adequate to maintain outflow, and, seemingly, the inflow from the Green River to River Styx should have been strong. The great head difference suggests an error in gagi-height reading; however, this cannot be determined. As flow again declined, River Styx, which is partly dammed by a low rock barrier at the outlet, was at progressively higher stages above the Green and Jcho Rivers.

The relationship between the ground-water reserroir under Mammoth Cave and the Green River is one that cannot now be adequately explained. Final conclusions will have to await results of tracer tests, collection of additional samples for chloride analysic the installation of a higher gage on the Echo River outlet, recorders on springs and subsurface streams upstream and downstream from the park area, and 
many readings on gages inside the cave. However, some significant conclusions can be drawn from the data already collected. Water from precipitation on the Pennyroyal plain and Mammoth Cave plateau flows through to the exit points, including River Styx and the Echo River, rapidly and creates a head differential sufficient to maintain normal flow from the springs into the Green River for as long as 2 days. After the initial surge of water, the height differential between River Styx outlet and the Green River decreases. At some stage, dependent on the rate of rise or fall of the Green River and the rate, amount, and distribution of precipitation on the Pennyroyal plain and the Mammoth Cave plateau, River Styx ceases to discherge into the Green River, and the turbid and sometimes saline high chloride water of the Green River flows into Mammoth Cave through the normal spring outlet. This reversed flow may last many days. Figure 13 shows reverse gradients several times on January 16-31, 1954.

Figures 14-16 show the relationship between the stages of River Styx and the Green River during three rises. Figure 14 shows the relative stages during a rise when base flow of the river was relatively high, April 30-May 19, 1954. The heary local rains probably resulted in intermittent discharge from River Styx, May 6-10, but except for the period of most rapid rise immediately after precipitation, the Green River stayed higher than River Styx and flowed into River Styx during the period April 30-May 16. This segment of record indicates that water flows from the Green River to River Styx most, of the time during winter and early spring, except when heary local rainfall causes a temporary surge of water to discharge from River Styx.

Figure 16 shows a rise which is probably typical of the period from late summer to early winter, when ground-water storage is low and the Green River is at a low stage. The precipitation at Mammoth Cave, December 22-23, 1958, was the first for about 20 days and the first heavy rainfall since early August. Although the river at no time was close to the stage of River Styx, stage and discharge from River Styx increased significantly for about 72 hours. At the same time, the stage of the Echo River rose and discharge increased. Thus, when ground-water storage is small and the Green River stage is low, heavy local rains generally result in discharge from both River Styx and the Echo River as well as from other springs in the area, and flow at River Styx is not reversed.

If reversals of flow occur in the Echo River, they probably are of short duration. All plottings of stage of the Green River and Echo River indicate a gradient from the Echo River to the Green River, although the gradient is not constant. Figure 15 shows the relationship between the stage of River Styx and the Green River during a rise on January 20-23, 1959, and the following decline. A separate 

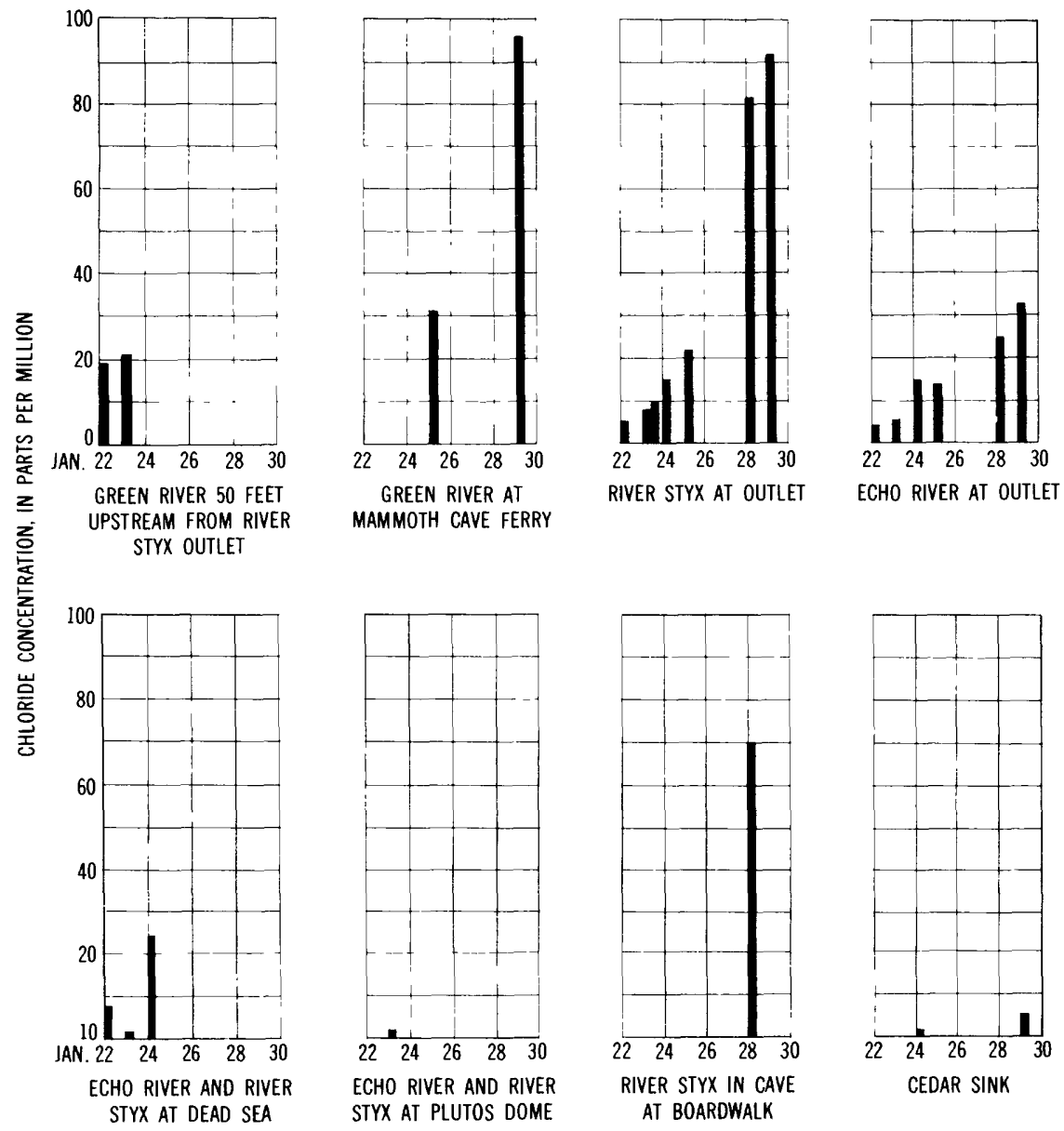

Figure 22.--Relation of chloride concentrations in water samples from groundwater to surface-water sources, January 22-29, 1959.

plotting on figure 15 shows concentration of chlor:de in parts per million for River Styx and the Echo and Green Rivers. Figure 22 shows chloride concentrations plotted as bar diagrams for the same period and includes chloride for several water bodies inside Mammoth Cave and Cedar Sink. Figure 15 includes chloride concentrations determined in the field by approximate methods; figure 22 includes only laboratory analyses and, thus, is more accurate but less comprehensive.

As shown by the arrows (fig. 15), River Styx alternately flowed in and out on January 23, 1959, when the stage of River Styx at the outlet was about 0.2 foot above the stage of the Green River at Mammoth Cave Ferry. This is probably the critical stage between flow from the cave passages to the Green River and reverse flow of the Green River into the cave passages. When the gage-heigl t differential is 
less than this, the Green River generally flows into the cave passages; when it is greater, River Styx generally discharges water to the Green River. However, beca use of siphon action and restrictions in the solution channels under Mammoth Cave plateau as well as surges in the flow of the Green River, the inflow-outflow relationship may not al ways depend on this exact stage differential. During any given half-hour period, the stage of River Styx may fluctuate several times through a range of 0.2 to 0.3 foot, resulting in alternate inflow and outflow. Thus, flow relationships illustrated in these hydrographs are only general. Note that discharge from River Styx to the Green River was principally during the period of rapidly rising and falling stages of the Green River (figs. 14, 15).

The chloride concentration in the Green River was about 20 ppm (parts per million) at the peak of the rise and $5-10 \mathrm{ppm}$ in the Echo River and River Styx during the same period (fig. 15). As the peak of the rise passed, the chloride concentration in each of the bodies of water generally increased. Local rainfall was heary on January 20 21, 1959, and River Styx, the Echo River, and other springs in the area probably discharged until noon January 22. At noon on January 23, a reverse flow was observed from the Green River into River Styx, and a sample of water from River Styx at the gaging station contained $15 \mathrm{ppm}$ chloride. By January 25, samples from River Styx contained $30 \mathrm{ppm}$ chloride, and the chloride content increased erratically until January 29 , when a sample contained $150 \mathrm{ppm}$ chloride.

During this period the Echo River was discharging into the Green. Although the rate of discharge is not known, the stage remained slightly above that of the Green River throughout the period shown. The concentration of chloride in the water discharging from the Echo River increased from about $5 \mathrm{ppm}$, during the period of maximum stage, to about $45 \mathrm{ppm}$ on January 29 , when the chloride content in River Styx was $150 \mathrm{ppm}$. Chloride concentrations in the sections of the Echo River inside Mammoth Care show a similar increase (fig. 22). The only possible source of the high chloride water in the Echo River is water from the Green River. Further, the close correlation of the change of concentration of chlorides in River Styx and the $\mathbf{E}$ cho and Green Rivers indicate that water from the Green River flows rapidly into the Echo River from River Styx or other upstream areas at high stages.

The water that discharges from the Echo River at high stages probably is a mixture of water from the Green River that flows into the cave through River Styx and water from precipitation on the Pennyroyal plain and Mammoth (ave plateau that flows through solution channels under Mammoth (ave Ridge and adjoining valleys. River Styx contains a high concentration of chloride even after long periods of continuous discharge; the source of the chloride is apparently water 
from the Green River that enters solution channels upstream from River Styx. A sample of water collected from River Styx on November 3,1958 , contained $25 \mathrm{ppm}$ of chloride, about 10 times the concentration of chloride in samples from this spring before contamination of the Green River by chloride in 1958. Gage-height records show that outflow from River Styx was constant for more than a month before this sample was collected.

It an upstream intake is the source of the high chloride in River Styx at low flow, some water probably comes in the same intake at high stages, mixes with water coming in through River Styx, and discharges from the Echo River. These rivers connect in the cave at high stages of flow, and the chloride concentration is high at some stages.

Figure 23 shows the relation of concentrations of chloride to discharge and time. Before 1959 the highest concentration of chloride determined was about $3 \mathrm{ppm}$, and it was relatively less during periods of high discharge than during periods of low discharge. In 1959, chloride concentration was more than $100 \mathrm{ppm}$ at some discharge rates and was generally higher at high discharge than at low discharge. This is probably water from River Styx that contains water high in chloride from the Green River crossing over at high stage and discharging into the Echo River. Thus, the reason that the Echo River does not reverse flow, even during the periods of rapid ris? of the Green River, must be that gradients in the complex system of solution channels in the cave are such that part of the Green River flows into the solution channels under the Mammoth Cave plateau anc', during high stages, discharges from the Echo River outlet. The Echo River, apparently, is not included in this system of flow at low stages.

A sample collected at the Echo River outlet on November 3, 1958, contained $2.5 \mathrm{ppm}$ chloride. A sample taken inside the ce.ve on November 4 (fig. 24) from the river contained $3 \mathrm{ppm}$ chloride, whereas a sample from River Styx inside the cave on the same date contained 36 ppm chloride. Water from the Pennyroyal plain and Mammoth Cave plateau has a concentration of chloride of about $5 \mathrm{ppm}$.

Much of the water that enters the solution channels from the Green River may be discharged at some point downstream fom the Echo River at high stages. If River Styx outlet is ever significantly lower in stage than the Echo and Green Rivers, it is obviously impossible for the inflow from the Green River to River Styx to discharge from the Echo River. Thus, if this stage relationship ever occurs, the reverse flow in River Styx must discharge at some point downstram from the Echo River. Figure 13 shows such a relationship on Jar uary 27, 1954. These readings may represent an error by the observer. If they are correct, however, they indicate a discharge point downstream from the Echo River. 


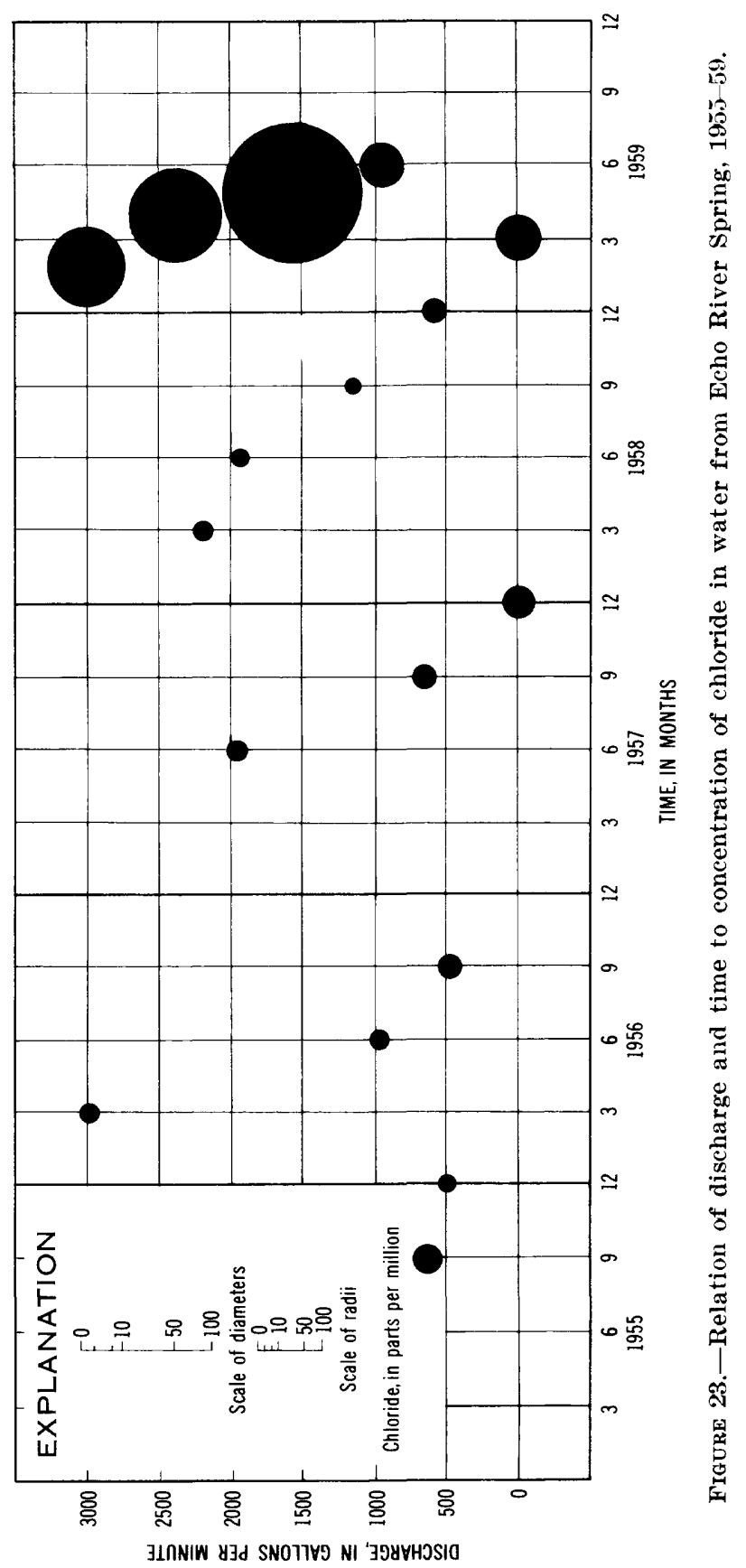




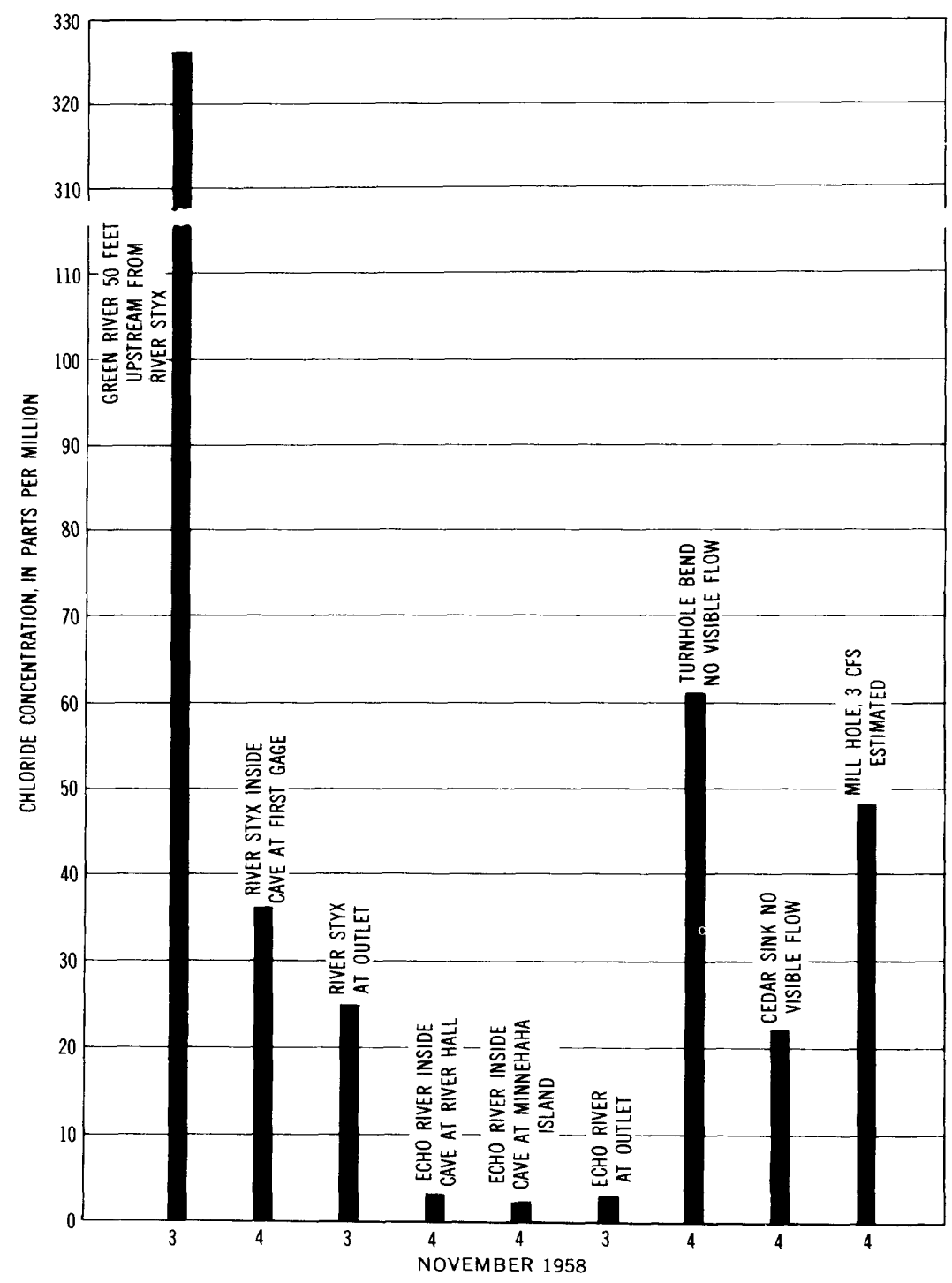

Figure 24.-Chloride concentrations in water samples taken from groundwater and surface-water sources, November $3-4,1958$.

Possibly, one or more major chamnels served as a bypass during normal water stages before the erection of the U.S. Corps of Engineers lock and dam 6 near Brownsville, and water now flows in these channels only when a gradient is established on the river during times of high water. Such channels might have innumerable obstructions, siphons, dead ends, and similar shapes and structures that could affect the rate of flow at different river stages. They might conduct water for several miles before it discharges into the Greer River. Such 
subterranean water courses are not uncommon in this part of Kentucky.

A few miles upstream from the national park boundary, many thousands of gallons per minute flow under the narrow ridge that divides two loops of a meander curve in the Green River instead of flowing around the ridge in the normal river channel. The discharge of water is visible for several hundred feet at river level, ard it is likely that many thousands of gallons more discharge from the side and bottom of the river channel. The rate of flow is so rapid that the temperature of the water declines during the summer by only about $5^{\circ}$ after passage through the ground. Normally, the temperature of water discharging from a spring would be about $20^{\circ}$ below the summer temperature of the Green River.

\section{SUMMARY}

The Mammoth Cave plateau is underlain by limestone of Meramec age and alternating limestone, sandstone, and shale formatiors of Chester age. The youngest bedrock formation in the area is the Cr seyville Formation of Pennsylvanian age.

Precipitation on the Pennyroyal plain or Mammoth Cave plateau is either dissipated by evapotranspiration or enters the ground-water body. Surface runoff in the areas south of the Green River is nogligible. Ground water may be delayed in its passage to the Green Fiver level by relatively impermeable shale layers and intricately channeled limestone, but it ultimately reaches that level and is discharged ints the Green River. Water levels in wells that intercept the water table coincident to the Green River fluctuate in much the same way as springs that discharge into the Green River. The stage of the Green River is for the most part independent of the discharge of local springs and water levels in wells. Possibly for this reason, water from the Green River at some stages flows backward into the cave passageways under Mammoth Cave plateau through the mouth of River Styx.

Contamination of the Green River by salt water high in chloride has made it possible to trace the movement of water from the Green River. This water flows into the solution channels in the Mammoth Cave area through River Styx and probably through openings in solution channels upstream from River Styx. Inside Mammoth Cave it mixes with water from the Mammoth Cave plateau and Pennyroyal plain and discharges through the Echo River and possibly through solution channels that connect with the Green River at some point downstream from the Echo River.

The Echo River almost always discharges into the Green River, but River Styx apparently discharges into the Green River principally at low stage and during rapid rises in stage. 


\section{SELECTED REFERENCES}

Bretz, J Harlen, 1942, Vadose and phreatic features of limestcne caverns: Jour. Geology, v. 50, no. 6, p. 675-811.

Cushman, R. V., Krieger, R. A., and McCabe, John A., 1965, I'resent and future water supply for Mammoth Cave National Park, Kentucky : U.S. Geol. Survey Water-Supply Paper 1475-Q, p. 601-647, 11 figs.

Davis, W. M., 1930, Origin of limestone caverns: Geol. Soc. America Bull., v. 41. p. $475-628$.

Dicken, S. N., 1935, A Kentucky solution cuesta: Jour. Geology, v. 43, no. 5, p. $539-544$.

Gardner, J. H., 1935, Origin and development of limestone caverns: Geol. Soc. America Bull., v. 46, p. 1, 255-1, 274.

Haynes, Donald D., 1962, Geology of the Park City quadrangle, Kentucky: U.S. Geol. Survey Geol. Quad. Map GQ-183.

—_ 1964, Geology of the Mammoth Cave quadrangle, Kertucky : U.S. Geol. Survey Geol. Quad. Map GQ-351.

Jillson, W. R., 1929, Geologic map of Kentucky : Kentucky Geol. Survey, ser. 6, scale $1: 500,000$.

Klemic, Harry, 1963, Geology of the Rhoda quadrangle, Kentucky: U.S. Geol. Survey Geol. Quad. Map GQ-219.

Livesay, Ann, 1953, Geology of the Mammoth Cave National Park area: Kentucky Geol. Survey, ser. 9, Spec. Pub. 2. 40 p.

Lobeck, A. K.. 1928, The geology and physiography of the Mammoth Cave National Park: Kentucky Geol. Survey, ser. 6, v. 31, pt. 5, p. 331-339.

McFarlan, A. C., Swann, D. H., Walker, F. H., and Nosow, Edmund, 1955, Some old Chester problems-correlations of lower and middle Chester formations of Western Kentucky : Kentucky Geol. Survey, Bull. 16, ser. 9, 37 p.

Pohl, E. R., 1955, Vertical shafts in limestone caves: Natl. Speleol. Soc. Occasional Papers 2, 23 p.

Richards, Paul W., 1964, Geology of the Smiths Grove quacrangle, Kentucky : U.S. Geol. Survey Geol. Quad. Map GQ-357.

Swinnerton, A. C., 1932, Origin of limestone caverns: Geol. Soc. America Bull.. จ. 43, p. $663-694$.

Weller, J. Marvin, 1927, Geology of Edmonson County: Kentucky Geol. Surrer, ser. 6 , v. 28,246 p.

Weller, J. Marvin, and Sutton, A. H., 1940, Mississippian border of Eastern Interior basin: Am. Assoc. Petroleum Geologists Bull., r. 24, no. 5, p. 765858. 


\section{INDEX}

[Italic numbers indicate major references]

Acknowledgments

Anclerson, R. B., cited

Beaver Dam Creek.

Big Clifty Sandstone Member of Golconda Formation $8,12,41,42,45,50,52$

hydrologic significance.......

Bransford Spring

Bransford well 1

Bruce Hollow

Caseyville Formation hydrologic significance

Cave Research Foundation

Caves, geologic history geologic horizon. levels of carern development

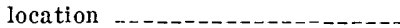
two-cycle origin

CCC No. 2, fluctuations of water level in well hydrograph of well_...

Cedar Sink__._._._._._. 9, 10, 46, 56

Cedar Spring Valley_._._....... 10, 48

Chaumont well_..._. 8 hydrograph _-_._._._. 41,52

Chester Series._... 6, 41

Chloride concentration, relation to discharge and time

water from $M$ a m moth Cave

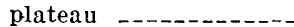

water from Pennyroyal plain.--

Chloride in Green River,_._._. 55, 56

Colossal cave_._._._.

Colossal Dome........-_._-_-_ 49

Crystal cave............. $9,11,12,38$

Davies, W. E., quoted..._._. 14

Dams, evaporite

Dome pits_._. 12

Doyel Valley_._._._._._._._._. 10,48

Discharge from lower ground-water body through springs - -

Drainage, dendritic underground

$6,9,11$ , 7

Dripping Springs escarpment__._. 2, 7 , $12,38,41,42,46,50,52$

Dye tests, Louisville Gas \& Electric $\mathrm{Co}$

Eaton Valley

Echo River $-13,15,49,61$

chloride concentration.

rise in water level
4 Echo River spring_-__-47, 49, 50, 53, 58

crradient

Escarpment west of Mammoth Cave area 11

Evaporite deposits

Evapotranspiration, water discharged through _.......... 50

Fairy Spring

Flint Ridge__._._. solution channels underlying_... $\quad 49$

Fluctuations of water levels_._._. 49

Fort Payne Formation_........ 2\% hydrologic importance......... 27

Garvin spring

Geologic formations, sequence_._._. 4,6 water bearing properties_...... 16

Girkin Formation_...... 39, $41,51,52$ hydrologic significance_....... 41

Glen Dean Limestone___._._. 44 hydrologic significance........ 44

Goedes, Warsaw Limestone_._._. 27

Golconda Formation, Big Clifty Sandstone Member._._. 6,8 , $12,41,42,45,50,52$

Haney Limestone Member..... 43 Great Onyx cave_... $9,11,38$

Green River...._. 13, 45, 46, 49 52,53 chloride concentration _._._. $5 \%, 61$ deposits of Pleistocene and Recent ages in flood plains -45 gradient _... 50 relationship between groundwater reservolr under Mammoth Cave_.... 54

rise in water level_......... 54 stage Green River basin, runoff Ground water, in solution openings in Girkin Formation movement _._._._._._. 46, 61 Ground-water storage_._._..... 55

Hamilton Valley Haney Limestone Member of the Golconda Formation_._- 48 hydrologic significance_-_._.... 43 Hardinsburg Sandstone__..._...- 43 hydrologic significance...... 43 Hidden River Spring, flow__._._. $\quad 32$ Historic Entrance._._._. 13 Houchens Valley_._._._._._._. 48,49 Hydrograph, Chaumont well__.__- 41, 52 Union City well_.._... 42, 50,54 well at CCC No. 2_....... 39, 52, 54 
Introduction

Jim Lee Ridge

Joppa Ridge.

Leitchfield Formation_........... hydrologic significance........ Location and extent of area.......Lonisville Gas \& Electric Co. dye tests 47,53

Mammoth Cave, precipitation $54,55,61$ relationship between groundwater reservoir and Green River.........

Mammoth Cave plateau_....... 2, 6, 8 , $38,41,42,45,54,61$

Mammoth Cave Ridge............ solution channels under.....--

Meramec Series

Mill Hole $7,8,11,46$

Mississippian System

Monroe Sink

New Discovery cave

Nolin River, deposits of Pleistocene and Recent ages in flood plains

Oolites, Ste. Genevie Limestone...Osage Series.

6,27

Pennsylvanian System

Pennyroyal plain__2, 6, 10, 11, 12, 32, 46, 61 concentration of chloride in water

Phreatic water.

Physiography

Piezometric surface

Pike spring .....................

Pleistocene deposits, hydrologic significance

sand and gravel

Precipitation $\ldots \ldots \ldots, 54,55,61$

Previous investigations ..........

Quaternary System

Recent deposits, hydrologic significance

sand and gravel.

Recharge from Green River

Recharge to lower ground-water body sources _............

River Hall. Sce River Styx.

River Sty $x_{-}$ chloride concentration ........ 57 rise in water level_._._._... 54

River Styx spring_..._._._. 48, 49, 50, 53

Roaring Riyer

Runoff, Green River basin......... 46

Sand Cave spring_........... 47,48

St. Louis Limestone_...... $7,12,28,52$ hydrologic significance.......-
Page

$\begin{array}{ll}\text { Temperature of water.-. } & 61 \\ \text { Terrace deposits on streams._. } & 45\end{array}$
45

38 hydrologic significance._._._. 38 oolites _..... 38

Scope and purpose of report_.... 1 Silt barriers in solution channels in caves _...........- 46

Sinkholes _...

Solution channels____._._._. 9,61 Girkin Formation_._. 41

Hanney Limestone member of Golonda Formation...- 43

in caves, silt barriers... 46

in St. Louis Limestcne_._._. 33 under Mammoth Cave plateau _- 57, 58 under Mammoth Cave Ridge_.-- $\mathbf{5 7}$ underlying Flint Ricge_._._. 49

Springs, Glen Dean Limestone_._._. 44 main source of discharge from area

Streams, ephemeral_....... 9, 11 perennial _._. underground _... 46

Summary

Surface runoff_....... 61

Three Springs_._._._._._._. 48,48

Topography _..... 4

karst _._. 11

Turnhole spring

Union City well, fluctuations of

water level_......... 50,53

hydrograph _._._._._. 42, 50,54

Vadose water, defined_......... 19

Valleys, subsequent__._......... 8

Vaughns Dome_._._. 49

Warsaw Limestone____._._. 27

hydrologic importance._._._- 28

Water-bearing properties of geologic
formations

Hardinsburg Sandstone..... 48

St. Louis Limestone__._._. $\quad 32$

Ste. Genevieve Limestone_._.- $\quad 39$

Warsaw Limestone_._-_._._. 27

Water-level fluctuation in wells.... $\quad 61$ records

Weller, J. M., quoted_____._ 45

Well-numbering system......... 3

Wells, alluvium__._. 45

Big Clifty Sandstone Member of Golconda Firmation.-- 42

Bransford 1_._._._. $\$ 9$

Girkin Formation._. 41

Hardinsburg Sandstone__.___. 43

St. Louis Limestone_._._._. $\quad 32$

Ste. Genevieve Limestone._._. $\quad 89$

Union City_..... 42

water-level fluctuations__._._._ 49, 50

32 Woolsey valley_____._. 48 